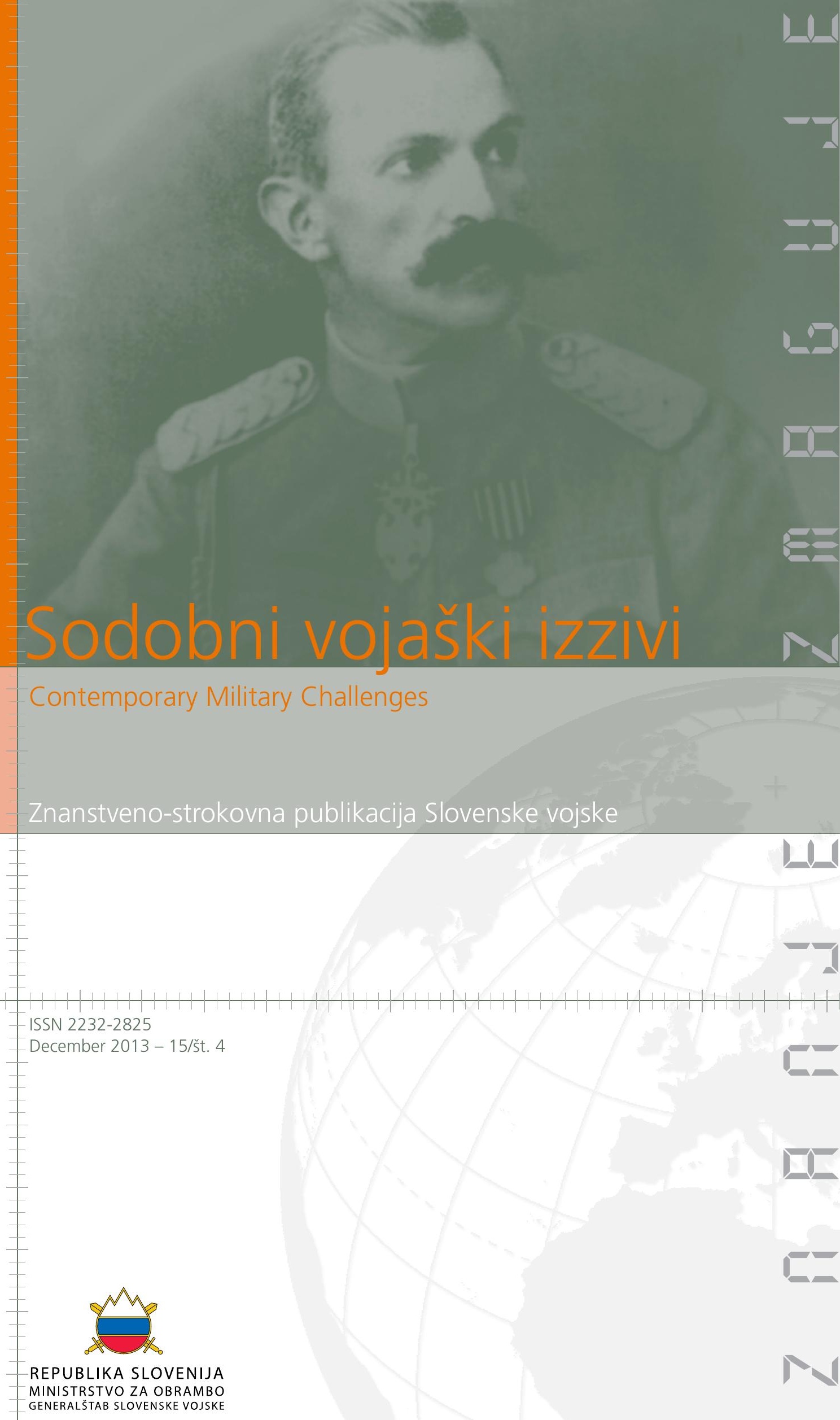




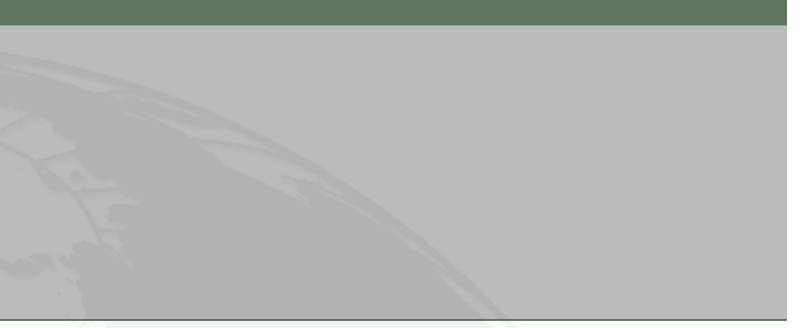

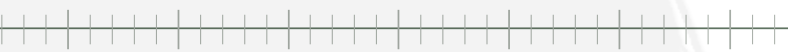




\section{Sodobni vojaški izzivi}

Contemporary Military Challenges

Znanstveno-strokovna publikacija Slovenske vojske

ISSN 2232-2825

UDK 355.5(479.4)(055)

December 2013 - 15/št. 4

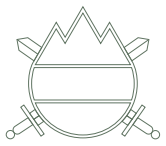

REPUBLIKA SLOVENIJA

MINISTRSTVO ZA OBRAMBO

GENERALŠTAB SLOVENSKE VOJSKE 
Izdajatelj

Publisher

Glavni urednik

Executive Editor

Odgovorni urednik

Managing Editor

Uredniški odbor

Editorial Board

Sekretar

Secretary

Uredniški svet

Editorial Council

Prevajanje

Translation

Korekture

Oblikovanje

Design \& Graphic

Tisk

Print

Naklada

Edition

Revija je dostopna

na spletni strani

Publication web page

E-naslov urednice

Managing Editor

e-mail address
Generalštab Slovenske vojske

General Staff of Slovenian Armed Forces

brigadir dr. Andrej Osterman

dr. Liliana Brožič

VVU XIII. razreda dr. Valerija Bernik VVU XIV. razreda dr. Denis Čaleta polkovnik dr. Tomaž Kladnik dr. Igor Kotnik

VVU XV. razreda msgr. dr. Jože Plut podpolkovnik dr. Boris Rutar dr. Uroš Svete

višji vodnik Stefan Tomanović

dr. Andrej Anžič, dr. Anton Bebler dr. Sabine Collmer, dr. Damir Črnčec generalmajor Ladislav Lipič dr. Thomas Mockaitis generalpodpolkovnik dr. Iztok Podbregar dr. Tibor Szvircsev Tresh

Iris Žnidarič

Šola za tuje jezike

Meta Brulec

Milena Sevšek Potočnik

Vesna Vrabič

Skupina Opus Design

Tiskarna Collegium graphicum, d. o. o.

$500 \mathrm{izvodov} /$ copies

http://www.slovenskavojska.si/publikacije/ sodobni-vojaski-izzivi/

http://www.slovenskavojska.si/en/publications/ contemporary-military-challenges/

liliana.brozic@mors.si

Prispevki, objavljeni v Sodobnih vojaških izzivih, niso uradno stališče Slovenske vojske niti organov, iz katerih so avtorji prispevkov.

Publikacija je uvrščena v bibliografsko zbirko podatkov COBISS.SI in PAIS International.

Articles, published in the Contemporary Military Challenges do not reflect the official viewpoint of the Slovenian Armed Forces nor the bodies in which the authors of articles are employed.

The publication is indexed in bibliography databases COBISS.SI and PAIS International. 


\section{OB 15-LETNICI IZHAJANJA SODOBNIH VOJAŠKIH IZZIVOV}

„Umetnost vojskovanja je znanost, v kateri ne uspe nič, kar ni preračunano in premišljeno.«

Napoleon (1769-1821)

(Moto v prvi številki iz leta 1999)

\section{UPON THE $15^{\text {TH }}$ ANNIVERSARY \\ OF THE CONTEMPORARY MILITARY CHALLENGES}

"The Art of War is a science, where nothing which is not well-calculated and well-considered will succeed."

Napoleon (1769-1821)

Motto from the first issue published in 1999. 



\section{VSEBINA}

CONTENTS

11

BILTENU NA POT

THE BULLETIN SETS OUT ON ITS WAY

13

OB PETI OBLETNICI BILTENA SLOVENSKE VOJSKE

UPON THE FIFTH ANNIVERSARY OF THE SLOVENIAN ARMED FORCES BULLETIN

\section{5}

OB TEJ IN PRIHODNJIH ŠTEVILKAH BILTENA SLOVENSKE VOJSKE IN THIS AND ALL THE FOLLOWING ISSUES OF THE SLOVENIAN ARMED FORCES BULLETIN

\section{9}

NOVEMU UREDNIŠKEMU ODBORU BILTENA SLOVENSKE VOJSKE NA POT THE NEW EDITORIAL BOARD OF THE SLOVENIAN ARMED FORCES BULLETIN SETS OUT ON ITS WAY 
Alojz Šteiner

Danilo Türk

Alojz Šteiner

Iztok Podbregar

Teodora Ivanuša
DESET LET IZHAJANJA BILTENA SLOVENSKE VOJSKE - NOVIM IZZIVOM NAPROTI TEN YEARS OF THE SLOVENIAN ARMED FORCES BULLETIN - TOWARDS NEW CHALLENGES

\section{9}

POPOTNICA BILTENU SLOVENSKE VOJSKE V DRUGO DESETLETJE A GUIDE-POST FOR THE SECOND DECADE OF THE BULLETIN OF THE SLOVENIAN ARMED FORCES

\section{1}

PROJEKTIRANJE PREOBLIKOVANJA STRUKTURE SIL VOJSKE PROJECTING THE TRANSFORMATION OF MILITARY FORCE STRUCTURE

\section{3}

RUDOLF MAISTER - STRATEŠKI VODJA

RUDOLF MAISTER - STRATEGIC LEADER

\section{3}

O RAZVOJU SLOVENSKE VOJSKE

ABOUT THE DEVELOPMENT OF THE SLOVENIAN ARMED FORCES

101

TIMSKO DELO V SLOVENSKI VOJSKI

TEAM WORK IN THE SLOVENIAN ARMED FORCES

121

PROLIFERACIJA OROŽJA ZA MNOŽIČNO UNIČEVANJE - JRKB/E: NOVODOBNI IZZIV VARNOSTNIM SILAM V BOJU PROTI TERORIZMU PROLIFERATION OF CBRN/E WEAPONS: A NEW CHALLENGE FOR SECURITY FORCES IN COUNTER-TERRORISM

129

AVTORJI

AUTHORS

137

NAVODILA AVTORJEM ZA OBLIKOVANJE PRISPEVKOV

143

INSTRUCTIONS FOR THE AUTHORS OF PAPERS 


\section{UVODNIK}

\section{Spoštovani!}

Pred vami je nova številka Sodobnih vojaških izzivov, drugačna od prejšnjih. Najzvestejši bralci boste kmalu opazili, da so avtorji že znani, vsebine pa danes niso najbolj aktualne. Nenavadno? Niti ne. S to številko končujemo obdobje, ki je bilo zelo pomembno za vojaško literaturo v Sloveniji. Revija izhaja že petnajst let. Sprva se je imenovala Bilten Slovenske vojske, pozneje pa so postali Sodobni vojaški izzivi. Publikacija, ki jo izdaja Generalštab Slovenske vojske, je tokrat posvečena glavnim in odgovornim urednikom, ki so v preteklosti skrbeli za njeno nastajanje. V uredniškem odboru menimo, da so bili zanjo verjetno najbolj odgovorni, zagotovo pa dovolj vztrajni, da se je publikacija obdržala, izhajala vedno pogosteje in redno, hkrati pa povečevala kakovost.

Odločili smo se, da se ob petnajstletnici izhajanja zahvalimo vsem, ki so vsa leta kakor koli prispevali k nastajanju revije. Ob tej priložnosti smo zbrali uvodnike glavnih in odgovornih urednikov, ki so zaznamovali pomembne obletnice ali spremembe $\mathrm{v}$ reviji. Poiskali pa smo tudi prve članke, ki so jih napisali za to publikacijo.

V prvem delu je iz uvodnikov razvidno, kateri so bili glavni trije razlogi, ki so bili izhodišče takratnemu načelniku Generalštaba Slovenske vojske za pripravo prve številke. Vsi nadaljnji uvodniki pa podrobno opisujejo namen in cilje publikacije. Opravijo kratek pregled opravljenega dela uredniških odborov, predstavijo trenutno stanje in pogled naprej. Prepričani smo, da je to najboljši način, kako predstaviti razvojno pot publikacije ob njenem jubileju.

Večina glavnih in odgovornih urednikov se je preizkusila tudi v pisanju in s svojim zgledom prispevala $\mathrm{k}$ nastajanju vojaškostrokovne literature, gradila in razvijala svojo strokovno kariero, nekateri pa tudi akademsko. Njihova prva dela, ki jih 
objavljamo v drugem delu jubilejne številke, predstavljajo pristope in motive za razmišljanje o vojski tistega in prihodnjega časa. Avtorje in njihove karierne poti podrobneje predstavljamo v posebnem poglavju.

Zahvaljujem se glavnim in odgovornim urednikom za njihov prispevek k razvoju publikacije, vsem članom uredniških odborov za vložen trud, lektoricam za skrb za slovenski jezik, prevajalkam za kakovosten prenos slovenskih misli v mednarodno okolje in še vsem, ki niso bili nikjer posebej imenovani, a brez njih ne bi bilo končnega izdelka.

Tudi v prihodnje računamo na vse, ki ste sodelovali do zdaj, in seveda na tiste, ki o tem še razmišljate. Sodobni vojaški izzivi bodo "priložnost, da bomo znanje, spoznanja in izkušnje posredovali zaposlenim v Slovenski vojski in tudi širšemu okolju, « in tako »imeli možnost strokovnega dokazovanja«, kar je bil cilj prvega in tudi vseh naslednjih glavnih in odgovornih urednikov. Od leta 2010 smo uvrščeni $\mathrm{v}$ mednarodno podatkovno bazo, kar pomeni mednarodno priznanje publikacije $\mathrm{v}$ znanstvenem in strokovnem smislu. Naš cilj je, da bi se uvrstili v še več takšnih baz in razširili ter okrepili sodelovanje $\mathrm{z}$ drugimi uredniškimi odbori.

Vabljeni k sodelovanju! 


\section{EDITORIAL}

Dear readers,

Welcome to the new issue of the Contemporary Military Challenges, which differs from others. The most loyal readers will soon notice that they already know the authors and that the discussed subjects are not really topical. Strange? Not really. This issue concludes the period, very important for military literature in Slovenia. We have been issuing our publication for fifteen years. Originally titled Slovenian Armed Forces Bulletin, the publication was later renamed Contemporary Military Challenge. This time, the publication, issued by the General Staff of the Slovenian Armed Forces, is devoted to executive and managing editors who have contributed to the creation of the publication in the past. According to the Editorial Board, they have probably been the ones most responsible and certainly persistent enough to provide for a continued issuing of the publication. Still more, with time, the publication was issued more frequently and regularly, while the level of quality increased. Upon its fifteenth anniversary, we wish to extend our appreciation to all who have in any way contributed to the creation of this publication. On this occasion, we have collected the editorials of executive and managing editors, marking important anniversaries or changes in our publication, as well as some of the first articles written for this publication.

In the first part, the editorials point to the main three reasons, which led the then Chief of the General Staff of the Slovenian Armed Forces to prepare the first issue of the publication. All other editorials, however, give a detailed description of the purpose and goals of the publication. They offer a short review of the work accomplished by the editorial boards, illustrate the current situation and provide a look ahead. It is our firm belief that such presentation best reflects the development of the publication on its anniversary. 
The majority of executive and managing editors have also made the effort to write for the publication, thus setting an example for the creation of military professional literature. They have built and developed their professional, some of them also their academic, careers. Their early works, published in the second part of this jubilee issue, present the approaches and motives leading to the reflexions about the military then and in the future. A special chapter is devoted to the presentation of authors and their career paths.

I extend my sincere gratitude to all executive and managing editors for their contribution to the development of the publication; all members of editorial boards for the invested effort; proof-readers for their care for the Slovenian language; translators for the quality transfer of Slovenian thoughts into the international environment, and all those who have never been mentioned, but have made the issuing of the final product possible.

We continue to count on all of those who have cooperated with us so far and, of course, on those would wish to do so in the future. The Contemporary Military Challenges will serve as the opportunity to share our knowledge, findings and experiences with those employed with the Slovenian Armed Forces as well as those from the wider environment. This will provide us with an opportunity to prove our expertise, which was the aim of the first and all of the following executive and managing editors.

Since 2010, the Contemporary Military Challenges has been indexed in an international database, which means that the publication has been recognised both scientifically and professionally. Our goal is to index the publication in additional databases as well as to expand and enhance cooperation with other editorial boards.

You are kindly invited to participate! 


\section{BILTENU NA POT}

\section{THE BULLETIN SETS OUT ON ITS WAY}

Pred vami je prva številka biltena. Pripravili smo ga za uresničevanje zlasti treh ciljev:

1. Celoten koncept sodobnega vojaškega managementa sloni na visoko usposobljenih, motiviranih kadrih. Ugotavljamo, da obstoječih prednosti, ki jih nudi velika koncentracija izkušenj in znanja zaposlenih v Slovenski vojski, ne izkoriščamo dovolj. Glasilo nam daje priložnost, da bomo znanja, spoznanja in izkušnje posredovali zaposlenim v Slovenski vojski in tudi širšemu okolju.

2. Posledica globalizacije in liberalizacije tržišč je, in tudi vedno bo, odhajanje najboljših kadrov iz organizacijskih enot. $Z$ vzpostavitvijo pogojev za razvoj kadrov, katerega del je možnost kreativnega delovanja v obliki objavljanja strokovnih člankov, bomo na nek način vplivali na urejeno prehajanje med organizacijskimi enotami in zaustavljali nekontrolirane odhode iz sistema ter strokovne članke tudi upoštevali pri opredeljevanju predlogov za napredovanje.

3. Z razporeditvijo na določeno dolžnost pridobi posameznik položajno avtoriteto. Da je bil izbran, je moral izpolnjevati predpisane pogoje, torej imeti formalno izobrazbo, ustrezne delovne izkušnje in zlasti mora biti vojaškostrokovno usposobljen. Navedene pogoje lahko strnemo v strokovno avtoriteto častnika, ki je enakega pomena kot položajna avtoriteta, vendar marsikdaj težje dosegljiva. Prav možnost objavljanja strokovnih člankov v našem glasilu lahko bistveno vpliva na upoštevanje strokovne avtoritete zaposlenih v Slovenski vojski. Vsi bomo imeli možnost strokovnega dokazovanja in s tem nas bodo sodelavci upoštevali kot strokovnjake, hkrati pa bomo tudi strokovno rasli, saj ne bomo objavljali znanih vsebin, pač pa novosti in znanja, spoznanja ter izkušnje iz drugih okolij.

Pričakujem, da bomo izkoristili dano priložnost in želim, da postane glasilo informator vseh zaposlenih, ena pomembnih literatur za izpopolnjevanje zaposlenih v Slovenski vojski, vzpostavljanje organizacijske kulture in tudi razvoj Slovenske vojske. 


\title{
OB PETI OBLETNICI BILTENA SLOVENSKE VOJSKE
}

\author{
UPON THE FIFTH ANNIVERSARY \\ OF THE SLOVENIAN ARMED FORCES BULLETIN
}

Medtem ko čas zabriše mnoga dejanja in jih potisne $\mathrm{v}$ pozabo, se zapisana beseda ohrani. S pisanjem se misli razjasnijo, z objavo pa jih posredujemo tudi drugim.

Strokovna vojaška in informativna publikacija, kakršna je Bilten Slovenske vojske, omogoča pripadnikom SV, da znanja, spoznanja in izkušnje predstavimo javnosti, hkrati pa se kot bralci seznanimo tudi s področji delovanja oboroženih sil, s katerimi se na dolžnosti ne ukvarjamo neposredno. Naš cilj ni samo članstvo v Natu, želeli bi, da postane Slovenska vojska ena tistih sodobnih ustanov, ki si prizadevajo za svoje zaposlene ustvariti delovno okolje, v katerem je mogoč tudi osebni in strokovni razvoj.

Bilten SV omogoča povezovanje, profesionalnost in obveščenost, kar so lastnosti sodobnih oboroženih sil, in prepričan sem, da moramo te možnosti še bolj izkoristiti. V petih letih je izšlo osem številk Biltena, v katerih je bilo objavljenih več kot petdeset člankov. Žal ugotavljam, da so bili avtorji strokovnih prispevkov, razen enega, le častniki. V prihodnje želim, da bi se povečanje pomena podčastniškega kadra SV odražalo tudi v številu strokovnih člankov podčastnikov. Tem je veliko, prav tako tudi potreb po strokovnih prispevkih, saj se na strateški in operativni ravni srečujemo z novimi procesi in opremo. Članki naj govorijo o vojaškem vidiku pridružitve SV članicam Nata, novi opremi in oborožitvi, postopkih, povezanih s profesionalizacijo, vplivu družbenih sprememb na vojaško okolje in o novih nalogah oboroženih sil. Skratka, želim, da Bilten Slovenske vojske postane revija, ki bo po strokovnosti vrhunska in po vsebini vodilna revija pri zapisovanju razvoja SV. Pri tem želim, da avtorji ohranijo kritično distanco do predmeta in da uporabijo znanstven pristop. To je edina pot do kvalitete in Bilten SV že hodi po njej. Pet let izhajanja je čas, ko so narejeni prvi koraki in ko iz obdobja »otroških bolezni« preidemo v zrelejše obdobje. 
Zasnova Biltena SV je dobra, zdaj jo je treba nadgraditi in oplemenititi. Naloga uredništva je, da skrbimo za kakovost objavljenih člankov, naloga vas pripadniki SV pa, da izkoristite priložnost in del vašega dela, vaše raziskave ter razmišljanja opišete in to delite $\mathrm{z}$ drugimi.

Pred nami so novi izzivi in nepopisani listi.

Srečno! 


\title{
OB TEJ IN PRIHODNJIH ŠTEVILKAH BILTENA SLOVENSKE VOJSKE
}

\author{
IN THIS AND ALL THE FOLLOWING ISSUES \\ OF THE SLOVENIAN ARMED FORCES BULLETIN
}

Po osmih letih izhajanja je pred nami nova številka Biltena Slovenske vojske $\mathrm{z}$ nekoliko spremenjeno zunanjo in novo notranjo podobo. To naj bi po svoje vplivalo tako na vsebino kot na kakovost prispevkov. Spremembe so bile porojene med snovalci novega Navodila za pripravo in izdajanje periodičnih publikacij Slovenske vojske, ena izmed njih je tudi Bilten. Začelo se je pred devetimi leti, na pobudo takratnega načelnika Generalštaba. Že na začetku izhajanja je bil Bilten postavljen na dobre temelje in je svoje poslanstvo do danes dobro opravil, čeprav je sčasoma presegel okvir dosedanjega navodila. Njegovo izhajanje je slonelo na prostovoljnem delu nekaj zanesenjakov, ki so poleg rednega dela, ki ga ni bilo malo, skrbeli za njegovo izhajanje. Njegova pot ni bila vedno lahka, saj je doživljal večje ali manjše zastoje in težave. Da pa bi mu bilo v prihodnosti lažje, smo v analizo dosedanjega dela ter snovanje in oblikovanje novega navodila vložili veliko truda in energije, kar pomeni, da smo se dela lotili resno in premišljeno.

Tako so periodične publikacije Slovenske vojske, in tudi Bilten, postavljene na nove temelje, pred nove izzive, $\mathrm{z}$ namenom, da bi bralcem ponudile višjo raven objavljenih prispevkov. Ta želja je pri odgovornih članih uredniških odborov Biltena tlela že nekaj let. Snovalci so si pri oblikovanju novega navodila zastavili visoke cilje, z vizijo in ambicijo, da bi bila kakovost in stremljenje k odličnosti vsem avtorjem vodilo in cilj pri pisanju prispevkov. Prispevala naj bi tudi k njihovemu usposabljanju za oblikovanje vsebin, ki jih pripravljajo za objavo v publikacijah Slovenske vojske, Ministrstva za obrambo in drugih ustanov, predvsem pa v Biltenu. Poleg tega smo z novim navodilom razširili krog piscev. V Biltenu lahko zdaj objavljajo tudi zunanji avtorji. Omogočena pa je tudi mednarodna izmenjava prispevkov s publikacijami podobnih vsebin. 
Bilten Slovenske vojske ostaja periodična vojaškostrokovna in informativna publikacija, namenjena izobraževanju in obveščanju javnosti o dosežkih ter izkušnjah na področju vojaških, vojaško-tehničnih in drugih ved, vendar na višji ravni.

Teme, ki jih avtorji izbirajo, so z vojaškega področja, od doktrinarnih in strateških zamisli, vedno aktualnih operatike ali taktike uporabe enot Slovenske vojske, do uporabe enot na mirovnih misijah in v operacijah pod vodstvom Nata, EU ali OZN. Dobrodošle bodo tudi teme o usposabljanjih, rezultatih streljanja in druge, ki v Slovensko vojsko prinašajo novo znanje in nove veščine. Pisci si lahko izberejo teme o organizaciji in organiziranosti Slovenske vojske, kakovosti na splošno ali odličnosti in dobrih praksah, ki so za vojsko zelo pomembne.

Tudi štipendisti ministrstva lahko s svojim znanjem prispevajo $\mathrm{k}$ nadaljnjemu razvoju Slovenske vojske. Za objavo lahko priredijo svoje vojaškostrokovne seminarske in zaključne oziroma diplomske naloge ter druga dela iz dodiplomskega študija. To velja tudi za študente podiplomskega študija oziroma njihova seminarska in podiplomska dela.

Z novim navodilom so lahko prispevki napisani v slovenskem jeziku, z naslovom, ključnimi besedami in povzetkom $\mathrm{v}$ angleškem jeziku, ali $\mathrm{v}$ angleškem jeziku, $\mathrm{z}$ naslovom, ključnimi besedami in povzetkom v slovenskem jeziku. V angleški jezik sta prevedena tudi kazalo in kolofon. Prispevki so opremljeni z oznako UDK, vrste člankov pa so določene s tipologijo COBISS. Tako smo dosegli, da bodo avtorji z objavo prispevkov dosegli točke za habilitacijo.

Vse to nam omogoča, da lahko glavni in odgovorni urednik načrtujeta tudi mednarodno sodelovanje in izmenjavo prispevkov.

O objavi prispevka odloča uredniški odbor pred oddajo v recenzijo. Vedeti pa je treba, da prispevkov z žaljivo ali neprimerno vsebino ne bo sprejemal. Opozarjamo tudi, da so objavljeni prispevki avtorski in ne predstavljajo stališč Slovenske vojske ali izdajateljev.

Da bi dvignili kakovost objavljenih prispevkov, smo se pri oblikovanju novega navodila odločili, da bo uredniški odbor sestavljen iz članov z akademskimi in strokovnimi naslovi, dopolnjevali pa ga bodo zunanji člani.

Za objavo v Biltenu morajo avtorji upoštevati navodilo za pisanje prispevkov, ki je v vsaki številki objavljeno na notranji strani zadnje platnice in na spletni strani. V navodilu so prikazani tudi klasifikacija zvrsti prispevkov in posamezni standardi ISO, ki jih je treba pri oblikovanju upoštevati.

Pripadnike Slovenske vojske vabimo, naj začnejo pripravljati prispevke, naj svoje sodelovanje v Biltenu sprejmejo kot izziv, saj bodo tako dokazali svojo strokovnost in željo po širjenju splošnega in posebnega znanja. Prepričani smo, da mora 
posameznik, če hoče uspeti, imeti resnično voljo, da svoje sposobnosti čim bolje uporabi za opravljanje pravega in ustvarjalnega dela. Tako lahko izrazi svojo celovito osebnost ter uresniči svoje želje in hrepenenja, kar bo omogočil tudi Bilten.

Pri oblikovanju svojih prispevkov bodo pripadniki Slovenske vojske in drugi spoznali, da je težek samo začetek. Že Sun $\mathrm{Cu}$, ki velja za največjega stratega vseh časov, je pred skoraj 3000 leti zapisal, da se še tako težka pot začne s prvim korakom. 


\title{
NOVEMU UREDNIŠKEMU ODBORU BILTENA SLOVENSKE VOJSKE NA POT
}

\author{
THE NEW EDITORIAL BOARD \\ OF THE SLOVENIAN ARMED FORCES BULLETIN \\ SETS OUT ON ITS WAY
}

Spoštovani bralci!

Bilten Slovenske vojske je začel izhajati na prelomu prejšnjega stoletja, v času, ko smo začutili potrebo po publikaciji, ki bi tako pripadnike Slovenske vojske kot Ministrstvo za obrambo seznanjala predvsem s strokovnimi prispevki, ki obravnavajo tematiko vojaških in vojaškotehničnih ved. Poleg tega je bilo veliko prispevkov namenjeno organizaciji, kadrovskim vprašanjem, uporabnosti enot in organiziranju Slovenske vojske, kar je ustvarjalo nove informacijske razsežnosti Biltena.

Čeprav so se glavni in odgovorni uredniki ter člani uredniškega odbora menjavali, je ostajala uredniška politika nespremenjena. Ostaja tudi dejstvo, da so sodelujoči vedno stremeli h kakovosti prispevkov, zato je bila uvedena nekakšna pozitivna selekcija, seveda brez zahtev po omejevalni cenzuri ali celo samocenzuri.

Tudi uredniški odbor $\mathrm{v}$ dosedanji sestavi se je zavedal, da morajo biti v Biltenu objavljeni le tisti prispevki, ki so kakovostni in nosijo v sebi pravo sporočilo. V zadnjih letih se Slovenska vojska vse bolj profesionalizira, zato je za njene pripadnike izrednega pomena obseg informacij, ki sporočajo vsebine s področij kadrovanja, organiziranosti Slovenske vojske, upravljanja človeških virov in drugih, za vojsko pomembnih področij.

Predvsem v zadnjem času je postalo nujno poznavanje doktrinarnih vprašanj, še posebej slovenske vojaške doktrine. Razumljivo je, da bodo prav vprašanja $\mathrm{s}$ tega področja ustvarila vrsto odgovorov in novih dilem, povezanih $\mathrm{z}$ vedno aktualnimi vprašanji s področja strategije, operatike in taktike. Za tem bodo prišla na vrsto tudi tista, ki zahtevajo odgovor na vprašanje, kako reševati vprašanja, povezana $\mathrm{z}$ uresničitvijo taktičnih in operativnih postopkov v najrazličnejših bojnih 
okoliščinah. Priznati moramo, da so bili dosedanji uredniški sestavi naravnani na navedene vsebine, ki so jih avtorji lahko objavljali v Biltenu. Ob novih nalogah Slovenske vojske, tako doma kot v tujini, pa se bo pojavila še vrsta novih, do zdaj nepubliciranih tem. Dosedanje izkušnje govorijo, da bo tudi novi uredniški odbor zmogel uresničevati svoje poslanstvo na podlagi pretehtane izbire piscev iz vrst dovolj motiviranih in strokovno usposobljenih pripadnikov vojske, ministrstva in strokovnjakov slovenskih univerz.

Dosedanji uredniški odbori so opravili izjemen premik v razumevanju svojega poslanstva in temeljnih nalog Biltena. Zavedali so se, da pomeni objavljanje v njem učinkovit prenos izkušenj in znanja ter teorije, pa tudi možnost za pridobivanje potrebnega védenja, ki pomaga pri nadgradnji kakovosti dela, izobraževanja in usposabljanja.

Iz napisanega je mogoče razbrati, da je Bilten Slovenske vojske periodična vojaškostrokovna in informativna publikacija, namenjena izobraževanju in obveščanju javnosti o dosežkih ter izkušnjah na področju vojaških, vojaško-tehničnih in drugih ved, in da je na visoki ravni.

V skoraj desetletju izhajanja je Bilten s svojimi prispevki skrbel za bogatitev prenosa znanja s posameznika na vse pripadnike Slovenske vojske. Prenos znanja na notranjo strokovno javnost pomeni prenos na vse pripadnike Slovenske vojske, posebno pa na tiste, ki se izobražujejo in usposabljajo, oziroma na tiste, ki hočejo biti pri svojem delu boljši, bolj ustvarjalni in inovativni.

Bilten Slovenske vojske je bil že ob začetku izhajanja postavljen na dobre temelje. Svoj namen oziroma poslanstvo, ki izhaja iz glavne misli na naslovnici »Znanje zmaguje«, je dobro oziroma zelo dobro izpolnil.

Po toliko letih izhajanja se je zdaj na podlagi novega navodila začel proces posodabljanja Biltena. Nekoliko sta se spremenili zunanja in notranja podoba. Navodilo naj bi dalo podlago za to spremembo in za izboljšanje vsebine ter kakovosti pisanja prispevkov.

Dosedanji uredniški odbor si je v tem mandatu naložil uresničitev pomembnega projekta - izdati novo navodilo za pripravo in izdajanje periodičnih publikacij Slovenske vojske, kar mu je tudi uspelo. Pri njegovi pripravi so bili postavljeni visoki standardi in cilji za kakovost prispevkov ter zunanjo podobo Biltena.

To vse je bilo narejeno, da bi Bilten Slovenske vojske še naprej izhajal kot kakovostna in sodobna publikacija. Prilagajati se mora času in novostim, da bo tako lahko še dolgo izpolnjeval svoje poslanstvo. Primerjati se mora s podobnimi tujimi publikacijami ter dosegati, včasih pa tudi presegati svoj namen. 
Za vse opravljeno delo se dosedanjemu uredniškemu odboru zahvaljujem. Opravil je zahtevno delo, ki je bilo učinkovito in polno zanosa. Dosegel je vse načrtovano, kar ni bilo vedno preprosto in razumljivo samo po sebi. Uspelo mu je povišati naklado, povečati število letnih izdaj ter z novim navodilom oblikovati oziroma ustvariti nove podlage za pripravo in izdajo publikacije. Na podlagi tega navodila je odboru uspelo dvigniti kakovost prispevkov in posodobiti Bilten kot periodično vojaškostrokovno publikacijo Slovenske vojske. Glede na videz, vsebino in kakovost prispevkov ga lahko primerjamo z drugimi podobnimi publikacijami $\mathrm{v}$ domovini in tudi $\mathrm{v}$ tujini.

Novemu uredniškemu odboru želim, da bi nadaljeval uspešno pot odbora, ki je končal svoj mandat. Želim mu še uspešnejše delo, saj že ima zastavljene nove, trdnejše podlage za nemoteno delo. Verjamem, da bo znal in zmogel najti in navdihniti potencialne pisce, ki imajo znanje in odprte oči za priložnosti. Tudi novi uredniški odbor bo moral znati odgovarjati na izzive časa in prihodnosti. 


\section{DESET LET IZHAJANJA \\ BILTENA SLOVENSKE VOJSKE - NOVIM IZZIVOM NAPROTI}

\section{TEN YEARS OF THE \\ SLOVENIAN ARMED FORCES BULLETIN - \\ TOWARDS NEW CHALLENGES}

Povzetek Desetletno obdobje izhajanja Biltena Slovenske vojske (Bilten SV) je priložnost za analizo prehojene poti, pa tudi za pogled v prihodnost. V članku so predstavljeni kvantitativni kazalci uspešnosti izhajanja publikacije: pregled izdanih številk, število prispevkov, število natisnjenih strani in obravnavanih vprašanj z različnih področij delovanja Slovenske vojske in širšega obrambnega sistema ter število avtorjev. Več kot 150 avtorjev je skupaj oblikovalo skoraj 200 predvsem strokovnih člankov. Na začetku leta 2008 je bil oblikovan novi uredniški odbor, že sedmi po vrsti, ki si je zastavil nekaj smelih ciljev, ki jih predstavljamo v nadaljevanju. Seveda pa so glavni izzivi povezani s ciljem uredniške politike, da se v razvrstitvi strokovnih publikacij Bilten SV uvrsti v višji razred, da se povečata strokovnost in število znanstvenih prispevkov, da tako postane ogledalo strokovnosti in profesionalnosti naše vojske. Temu izzivu sledijo predstavljena vizija in strategija uredniškega odbora ter predvsem povabilo k širjenju kroga ustvarjalcev in mreže prejemnikov oziroma bralcev.

Ključne Uredniški odbor, uredniška politika, analitični pregled dosedanjih publikacij, besede prihodnji izzivi za Bilten $S V$.

Abstract The tenth anniversary of the Slovenian Armed Forces' Bulletin (in the further text: SAF Bulletin) provides an opportunity to make an in-depth analysis of the past and a view to the future. The article presents analytical indicators of the past period and achievements in terms of the number of issues, printed pages and topics covering various areas of Slovenian Armed Forces' operations and beyond. More than 150 authors have participated in the creation of almost 200 predominantly subject-matter related articles. The beginning of the year 2008 saw the establishment of the new editorial board, the seventh in the row that set some ambitious goals also described in this article. The main challenges are linked with the desire and goal of the SAF 
Bulletin editorial policy to improve its ranking in the classification of professional publications, to upgrade the level of professionalism and to increase the number of scientific articles, thereby reflecting the level of expertise and professionalism of the Slovenian Armed Forces. This challenge is the basis for the presented vision and strategy of the editorial board and, most of all, an invitation to expand the network of authors, subscribers and readers.

\section{Key words Editorial board, editorial policy, analytical overview of past publications, future} challenges for the Slovenian Armed Forces'Bulletin.

Uvod Deseta obletnica Biltena SVje prava priložnostza analizo prehojene poti in prepoznavo izzivov za prihodnost. Članek predstavlja najpomembnejše ugotovitve iz analize njegovega desetletnega izhajanja. Posebej obravnava poslanstvo in nove izzive ter organizacijo in delovanje uredniškega odbora. Na podlagi spoznanj in pridobljenih izkušenj so opredeljeni cilji in vizija za nadaljnje delovanje ter doseganje osrednjega cilja, to je prehoda iz četrte v tretjo skupino strokovnih publikacij. Namen članka je predstaviti desetletno izdajanje in nadgradnjo dosedanjih izkušenj pri snovanju Biltena za doseganje uredniških ciljev v prihodnosti, iskanje možnosti za širjenje kroga piscev in pripravo prispevkov za njihovo izpopolnjevanje ter predvsem širjenje kroga strokovne in kritične javnosti za teme in vprašanja, ki jih objavljamo.

\section{IZDAJATELJSTVO NA MINISTRSTVU ZA OBRAMBO}

Obrambne znanstvene discipline, veščine in delovni procesi se zaradi posebnosti obrambno-vojaškega področja razlikujejo od sorodnih in tistih zunaj obrambne sfere. Poleg tega je zaradi razvejanosti področja, številčno omejenega kroga uporabnikov in strokovne javnosti v posebnem položaju tudi notranja strokovna komunikacija. Zato ministrstva za obrambo vključno z vojaškimi strukturami opravljajo izdajateljsko in založniško dejavnost. Ta je v sodobnih razmerah globalne družbe in mednarodnih vojaških povezav ter zavezništev v posebnem položaju. Pri tem so vprašanja enotnega pristopa, racionalizacije, doseganja ciljev medijske in strokovne podobe organizacije ter ne nazadnje izrabe novih komunikacijskih medijev in metod resen izziv. Zapisano velja tudi za Republiko Slovenijo oziroma Ministrstvo za obrambo (MO) in Slovensko vojsko ${ }^{1}$.

V MO je bil z reorganizacijo leta 2008 narejen korak za vzpostavitev enotne in procesno povezane izdajateljske dejavnosti v Službi za založništvo (pred tem Služba za publicistiko), pri čemer so se ohranili funkcijsko ločeni izdajatelji, kot so: Slovenska

\footnotetext{
Organiziranje in delovanje založniške dejavnosti v MO je opredeljeno v Pravilniku o založniški in filmski dejavnosti v MO RS (št. dok. 811-11-7/2005-34 z dne 24. 7. 2006). Po pravilniku založniška dejavnost obsega načrtovanje, pripravo in izdajanje vojaškostrokovne in druge literature v tiskani in elektronski obliki ter namizno založništvo.
} 
vojska $^{2}$, Uprava Republike Slovenije za zaščito in reševanje, Obveščevalnovarnostna služba ter organizacijske enote upravnega dela MO. Kljub temu je ta dejavnost $\mathrm{v}$ nekaterih pogledih še vedno procesno razdeljena ali razdrobljena, predvsem pri izdajanju informativnih in periodičnih publikacij, kot so bilteni in zborniki, pa tudi pri pripravi in izdajanju vojaškostrokovne literature s področja znanstvenoraziskovalne dejavnosti ${ }^{3}$. Razdrobljenost se kaže tudi v tem, da enovito vodenje kot pomembna sestavina učinkovite medijske in javne podobe obrambnega sektorja ter njegovih organizacijskih enot ni vzpostavljeno. Tudi procesi, povezani z organizacijo tiskanja, niso povsem usklajeni, saj potekajo v dveh organizacijskih enotah. K temu lahko dodamo še dve vrsti pristopov k izdajateljski dejavnosti. Prvi poteka prek pristojne Službe za založništvo in s sodelovanjem Sektorja za naročila Direktorata za logistiko, drugi pa mimo pristojnih služb, z neposredno oddajo del zunanjim izvajalcem. V MO poleg revije Slovenska vojska, ki namenja pomemben del svoje vsebine vojaškostrokovnim temam, izhaja še Bilten SV. Vojaškostrokovna publikacija Vojstvo, ki je izhajala pred leti, formalno ni ukinjena, vendar ne izhaja. V PDRIU že deveto leto izhaja revija Vojaška zgodovina, ki uvaja nove pristope, predvsem pa se odpira tudi v mednarodni prostor, ne samo v slovenskega. Tako zagotavlja bolj prepoznavno zastopanje vojaškozgodovinske stroke. PDRIU izdaja tudi Vojaškošolski zbornik. Razmejitev ali bolje uskladitev vsebinskih področij, ki jih pokrivajo posamezne publikacije MO, ni dokončno opravljena, saj manjka ustrezen krovni akt o izdajateljski politiki ali strategiji. To na eni strani omogoča proste roke uredniškim odborom pri določanju ciljev in snovanju posameznih publikacij, na drugi pa posamezne publikacije zaradi tega ne morejo doseči višje strokovne ravni ali se izogniti tematskemu oziroma vsebinskemu podvajanju. Tehnično se posamezne izdaje usklajujejo z letnimi in dvoletnimi načrti izdelave literature, ki jih odobri minister za obrambo. Kako obsežna in pomembna je izdajateljska dejavnost v MO, dokazuje letni načrt publikacij za leto 2008, ki predvideva več kot 160 različnih publikacij v obsegu skoraj 2000 avtorskih pol in z nekaj več kot 1.050 .000 tiskanimi listi ter finančnim proračunom 857.000 evrov. K temu SV prispeva skoraj 100 različnih publikacij. V te načrte do zdaj večinoma niso bile vključene promocijske publikacije, kot so glasila poveljstev, enot, operacij in misij, pa tudi drugo promocijsko gradivo (zgibanke, mape, predstavitveni CD idr.).

Z opisanim pa seznam posebnosti ni končan. Navodilo za pripravo in izdajanje periodičnih publikacij SV iz leta 2007 (Navodilo 2007: 4-6) v členih od 8 do 12 določa posebnosti $\mathrm{v}$ organiziranju in sestavi organov publikacij, pristojnostih notranjih organizacijskih enot pri opravljanju nalog založništva in recenzijah. Ena temeljnih posebnosti so položaj in določitev (z odredbo) glavnih urednikov

\footnotetext{
Za izdajatelja in založnika je po Navodilu za pripravo in izdajanje periodičnih publikacij Slovenske vojske določen PDRIU (Navodilo 2007: 5. in 10. člen). PDRIU je po Pravilniku o založniški in filmski dejavnosti v MO iz leta 2006 znotraj SV pristojen za izdajanje doktrin, navodil, metod in meril, učno-izobraževalne literature ter periodičnih publikacij.

3 V Pravilniku o založniški in filmski dejavnosti v MO RS publiciranje s področja znanstvenoraziskovalne dejavnosti ni omenjeno, prav tako ne promocijsko gradivo različnih služb v MO in predvsem promocijsko gradivo poveljstev in enot, operacij ter misij SV.
} 
in uredniških odborov ter struktura članstva $\mathrm{v}$ uredniških odborih ${ }^{4}$, ki sama po sebi kliče na »samocenzuro« ali »cenzuro po hierarhiji«. Takšne rešitve kažejo, da so te publikacije zaprte $\mathrm{v}$ notranji krog organizacije in $\mathrm{v}$ posebnem odnosu do izdajatelja. Po eni strani je to lahko ovira za odprtost in dostop do širše strokovne in znanstvene sfere, pa tudi tujine. Po drugi strani pa postavlja pod vprašaj mehanizem odgovornosti in njeno uveljavljanje glede na to, da gre za prekrivanje funkcijske službene odgovornosti z odgovornostjo v uredniškem odboru. V podobnem položaju je vprašanje sprejemanja uredniške politike, za katero so po Navodilu pristojni uredniški odbori. Ker ni programskih svetov publikacij ${ }^{5}$, se postavljata vprašanji razmerja med založnikom in uredniškim odborom ter potrditve uredniške politike oziroma pridobitve usmeritev zanjo. Tretjo posebnost smo že delno opisali, povezana pa je z odnosom in razmerjem uredniškega odbora do notranjih organizacijskih enot v SV in MO, ki so funkcijsko pristojne za letno načrtovanje publikacij, finančno zagotovitev ter seveda za zagotovitev postopkov tiskanja in distribucije. Gre za odnos med formalnimi organizacijskimi enotami in neformalnimi, kar nedvomno so uredniški odbori glede na status. Razmislek o navedenih in drugih odprtih vprašanjih, pa tudi o racionalizaciji postopkov izdajateljske in založniške dejavnosti MO, tako kliče po uskladitvi in dodatni ali ponovni prenovi.

\section{DESET LET IZHAJANJA BILTENA SV}

Bilten SV je periodična vojaškostrokovna in informativna publikacija, namenjena izobraževanju ter obveščanju javnosti o dosežkih in izkušnjah s področja vojaških, vojaško-tehničnih in drugih ved (Navodilo 2007: 4. čl.). Iz navedene opredelitve izhaja, da je Bilten SV strokovna publikacija Generalštaba SV, namenjena obveščanju in izobraževanju pripadnikov SV, obveščanju drugih obrambnih struktur in javnosti o vojaškostrokovnih področjih ter predstavljanju znanja in izkušenj tujih oboroženih sil in njihovih izobraževalnih ustanov v slovenskem prostoru. Bilten SV omogoča pripadnikom Slovenske vojske in drugim zaposlenim v MO, da svoje strokovno znanje, spoznanja in izkušnje ter zamisli predstavljajo in širijo. Namenjen je tudi štipendistom ministrstva, da lahko predstavljajo izbrane študijske prispevke ter ugotovitve seminarskih in zaključnih nalog. Bilten je odprt predstavnikom obramboslovne strokovne javnosti za predstavljanje znanstvenih oziroma strokovnih prispevkov s področij, ki jih izbira uredniški odbor. Navedeno kaže na to, da je bila dosedanja programska orientiranost zelo široka. Ugotavljamo tudi, da med Biltenom SV, Vojstvom in Vojaškošolskim zbornikom ni bila opravljena razmejitev programske orientiranosti ter ciljnih področij in javnosti, v katere je usmerjena posamezna publikacija. Če se zapisano bere kot kritika, pa je to na drugi strani vendarle omogočilo preživetje in uveljavitev Biltena SV. Dokončna določitev

\footnotetext{
Za uredniške odbore ni formacije, ki je podlaga vojaške organiziranosti. Dejstvo pa je, da se zaradi položajev, ki jih imajo člani uredništev iz SV oziroma MO, „vojaškemu organiziranju« težko izognemo.

5 Navodilo za pripravo periodičnih publikacij SV pri opredeljevanju organov publikacij v 8. členu pri uredniških odborih omenja le razširjeno sestavo uredniških odborov, katerim glavni uredniki najmanj enkrat na leto poročajo o svojem delu in delu uredniških odborov. Razširjeno sestavo uredniškega odbora Biltena SV sestavljajo načelnik Generalštaba SV, poveljnik sil in poveljnik PDRIU.
} 
in uskladitev programske usmerjenosti različnih periodičnih publikacij MO pa tako ostaja izziv za prihodnje.

V nadaljevanju bomo analitični vpogled ${ }^{6} \mathrm{v}$ dosedanje številke Biltenov SV opravili s pregledom uredniških odborov ter izdanih številk in prispevkov. Posebej bomo analizirali strukturo objavljenih prispevkov po vsebinskih področjih in avtorjih. Iz tabele 1 izhaja, da so v obdobju od 1999 do 2008 uredniški odbor vodili štirje glavni in štirje odgovorni uredniki. Skupaj je bilo vanj vključenih 97 članov, od tega 44 različnih oseb. V opazovanem obdobju je bilo izdanih 23 številk.

\begin{tabular}{|c|c|c|c|c|c|c|}
\hline \multirow{9}{*}{$\begin{array}{r}\text { Tabela 1: } \\
\text { Pregled sestave } \\
\text { uredniških } \\
\text { odborov Biltena } \\
\text { SV v obdobju od } \\
1999 \text { do } 2008^{7} \\
\text { (vključno s } \\
\text { številko 10/Št. 3) }\end{array}$} & $\begin{array}{l}\text { Zap. } \\
\text { št. }\end{array}$ & Glavni urednik & Odgovorni urednik & Obdobje & $\begin{array}{l}\text { Število } \\
\text { izdanih } \\
\text { številk }\end{array}$ & $\begin{array}{l}\text { Skupno } \\
\text { število } \\
\text { članov UO }\end{array}$ \\
\hline & 1 & $\begin{array}{l}\text { generalpodpolkovnik } \\
\text { mag. Iztok Podbregar }\end{array}$ & \multirow{2}{*}{ brigadir mag. Alojz Jehart } & $\begin{array}{c}1 \text { leto } \\
\text { in } 7 \text { mesecev }\end{array}$ & 3 & 14 \\
\hline & 2 & \multirow{2}{*}{$\begin{array}{l}\text { brigadir } \\
\text { Ladislav Lipič }\end{array}$} & & 5 mesecev & 1 & 13 \\
\hline & 3 & & brigadir Anton Turk & 6 mesecev & 1 & 15 \\
\hline & 4 & \multirow{2}{*}{$\begin{array}{l}\text { generalmajor } \\
\text { Ladislav Lipič }\end{array}$} & brigadir Bogdan Beltram ${ }^{9}$ & $\begin{array}{c}3 \text { leta } \\
\text { in } 10 \text { mesecev }\end{array}$ & 7 & 18 \\
\hline & 5 & & major Evgen Primožič & 5 mesecev & 1 & 13 \\
\hline & 6 & $\begin{array}{l}\text { generalpodpolkovnik } \\
\text { Albin Gutman }\end{array}$ & \multirow{2}{*}{$\begin{array}{l}\text { podpolkovnik } \\
\text { Evgen Primožič }\end{array}$} & $\begin{array}{c}1 \text { leto } \\
\text { in } 8 \text { mesecev }\end{array}$ & 7 & 14 \\
\hline & 7 & $\begin{array}{l}\text { generalmajor } \\
\text { mag. Alojz Šteiner }\end{array}$ & & $\begin{array}{l}8 \text { mesecev } \\
\text { (do 10/'08) }\end{array}$ & 3 & 10 \\
\hline & \multicolumn{4}{|c|}{ Skupaj: } & 23 & $97^{10}$ \\
\hline
\end{tabular}

Prva številka Biltena SV je izšla novembra 1999. Do oktobra 2008 je bilo izdanih 23 številk, od tega 7 tematskih. Objavljenih je bilo 194 prispevkov na skoraj 3500 straneh. Ugotovimo, da je bilo v prvih sedmih letih izdanih 12 številk in objavljenih 95 prispevkov ali 48 odstotkov vseh. V zadnjih treh letih se je intenzivnost povečala, saj je bilo izdanih 11 številk s skupaj 109 prispevki ali 52 odstotki vseh. Povečanje števila izdaj je posledica uredniške politike, da se na leto oblikujejo po štiri številke,

${ }^{6}$ Kvantitativni del analize je opravil mag. Uroš Trinko iz GŠSV, za kar se mu zahvaljujem.

Upoštevano obdobje delovanja uredniškega odbora od septembra 1999 do oktobra 2008.

${ }_{8}$ Izdajanje Biltena SV se je začelo v obdobju načelnikovanja generalpodpolkovnika Iztoka Podbregarja, ki je odobril zamisel zanj in podpiral izdajanje. Mag. Iztok Podbregar je leta 2000 dosegel doktorski naziv.

9 Brigadir Bogdan Beltram je bil edini odgovorni urednik Biltena, ki se je do sedaj kot svetovalec načelnika Ğ́ ukvarjal predvsem z urednikovanjem, drugi odgovorni uredniki so kot prednostne opravljali druge naloge $v S V$.

${ }^{10}$ V sestavi uredniških odborov je bilo do zdaj 18 žensk, od tega 17 iz MO, ena pa ni zaposlena v obrambnem sistemu. 
med katerimi so tudi tematske. S tematskimi izdajami se poskušajo celoviteje in interdisciplinarno obdelati posamezna vprašanja ali tematska področja, ki so bila pred tem obravnavana na konferencah ali simpozijih v MO. Tako je bila tretja številka v osmem letniku (skrajšano 8/Št. 3) namenjena vprašanjem upravljanja znanja na MO, številka 8/Št. 4 pa ugotovitvam iz raziskave Človeški dejavnik v vojaškem sistemu. Številki 9/Št. 2 in 10/Št. 3 obravnavata protiterorizem, številka 9/ Št. 3 krizno upravljanje, številka 10/Št. 1 izobraževanje častnikov SV v prihodnosti ter številka 10/Št. 2 obvladovanje stresa v SV. V tabeli 2 je prikazana dinamika izdaj v posameznih letih, vključno do številke 10/Št. 3.

\begin{tabular}{|c|c|c|c|c|c|c|}
\hline \multirow{12}{*}{$\begin{array}{r}\text { Tabela 2: } \\
\text { Pregled številk } \\
\text { in prispevkov } \\
\text { Biltena SV po } \\
\text { letnikih od } 1999 \\
\text { do } 2008\end{array}$} & Letnik & $\begin{array}{l}\text { Številke v } \\
\text { letniku }\end{array}$ & $\begin{array}{l}\text { Število } \\
\text { tematskih } \\
\text { izdaj }\end{array}$ & $\begin{array}{c}\text { Število } \\
\text { navadnih } \\
\text { izdaj }\end{array}$ & $\begin{array}{c}\text { Število } \\
\text { prispevkov }\end{array}$ & Število strani \\
\hline & 1 (1999) & 1 & & 1 & 10 & 125 \\
\hline & $2(2000)$ & 2 & & 2 & 16 & 152 \\
\hline & $3(2001)$ & 2 & & 2 & 11 & 217 \\
\hline & $4(2002)$ & 2 & & 2 & 11 & 272 \\
\hline & $5(2003)$ & 2 & & 2 & 18 & 314 \\
\hline & 6 (2004) & 1 & & 1 & 6 & 180 \\
\hline & 7 (2005) & 2 & & 2 & 13 & 276 \\
\hline & $8(2006)$ & 4 & 2 & 2 & 39 & 718 \\
\hline & 9 (2007) & 4 & 2 & 2 & 32 & 672 \\
\hline & $10(2008)$ & 3 & 3 & & 38 & 567 \\
\hline & Skupaj & 23 & 7 & 16 & 194 & 3493 \\
\hline
\end{tabular}

Zanimiv je vpogled v strukturo objavljenih prispevkov, ki potrjuje, da je Bilten SV tipična vojaškostrokovna publikacija. V desetih letih obravnava vojsko 131 člankov od 194, kar je 68 odstotkov, medtem ko obrambne zadeve brez vojske obravnava 54 člankov ali 28 odstotkov, preostalih 9 prispevkov so uvodniki, ki smo jih uvrstili v kategorijo drugo. Zanimivo je, da je leta 2004, ko je Republika Slovenija vstopila v zvezo Nato in se pridružila EU, izšla le ena številka s 6 članki. Od leta 2006 so bile vse številke pospremljene $\mathrm{v}$ javnost z uvodnikom, bodisi načelnika Generalštaba bodisi odgovornega urednika, v zadnjem letu pa tudi tako imenovanega gostujočega urednika. Na grafu 1 je prikazano razmerje med članki o vojaških zadevah ter članki o širših obrambnih zadevah, in sicer je struktura objavljenih prispevkov glede na število strani v razmerju $65: 34$, izraženo v odstotkih. 

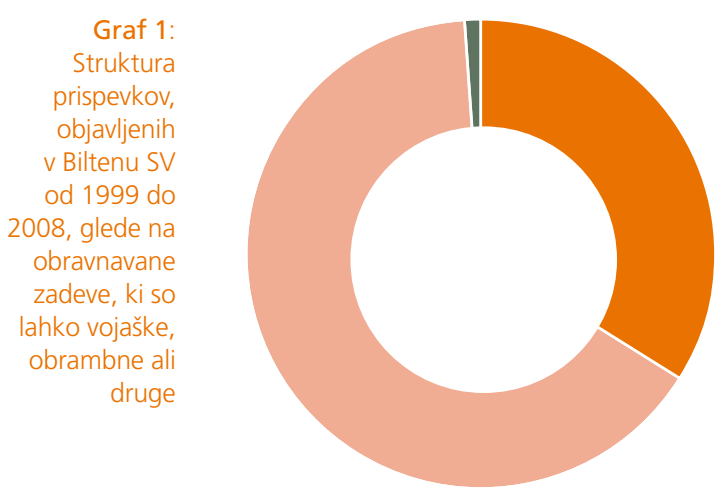

Obrambne zadeve $34 \%$

Vojaške zadeve $65 \%$

Drugo $1 \%$

Vsebinska analiza člankov pokaže, da se znotraj vojaških zadev pojavlja dvanajst področij. Pri tem so bile največkrat obravnavane vsebine protiterorizma s 23 članki ali devetimi odstotki ter izobraževanja in usposabljanja z 22 članki ali 11 odstotki, sledijo pa psihološka dejavnost (18 člankov, 7 odstotkov), kadrovsko področje (17 člankov, 9 odstotkov) ter operativno področje in štabno delo (13 člankov, 8 odstotkov). Pri obrambnih zadevah je bilo objavljenih največ člankov z vsebinami o teoriji organizacije in menedžmenta, in sicer kar 28, kar je 14 odstotkov, ter obrambne politike (10 člankov, 4 odstotki). Pregled člankov po strukturi je predstavljen v tabeli 3. Natančen pogled v strukturo člankov po področjih potrjuje trditev, da je po prenehanju izhajanja Vojstva njegovo vlogo prevzel Bilten SV. Razveseljuje podatek o številu objav o dveh najbolj aktualnih temah zadnjega časa, to je terorizmu in protiteroizmu ter o organizaciji vojaškega izobraževanja za SV. Manj razveseljiva je ugotovitev, da je bil s področja nabavne logistike v desetih letih objavljen le en članek in da ni bilo nobenega članka o Evropski obrambni agenciji (European Defence Agency - EDA) ali o kartografiji in podpori GIS (geografski informacijski sistemi). Prav tako v Biltenu SV do zdaj ni bilo objavljenih člankov o demokratičnem nadzoru nad oboroženimi silami, o podobi vojske v javnosti ali podpori vojske v nalogah zaščite in reševanja. Zapisano kaže na pomanjkljivostno nišo. 
Tabela 3:

Struktura

člankov,

objavljenih v

Biltenu SV, glede na področje $e^{11}$

\begin{tabular}{|c|c|c|c|c|}
\hline Vrsta zadev & Področje & $\begin{array}{l}\text { Število } \\
\text { člankov }\end{array}$ & $\begin{array}{l}\text { Število } \\
\text { strani }\end{array}$ & Odstotki \\
\hline \multirow{12}{*}{ Vojaške zadeve } & kadrovsko področje & 17 & 328 & 9 \\
\hline & obveščevalno področje & 4 & 91 & 3 \\
\hline & operativno področje in štabno delo & 13 & 282 & 8 \\
\hline & izobraževanje in usposabljanje & 22 & 369 & 11 \\
\hline & logistično področje & 9 & 189 & 5 \\
\hline & področje C4I & 5 & 136 & 4 \\
\hline & civilno-vojaško sodelovanje & 3 & 39 & 1 \\
\hline & Nato in EU & 4 & 26 & 1 \\
\hline & operacije & 3 & 31 & 1 \\
\hline & voditeljstvo in etika & 10 & 184 & 5 \\
\hline & protiterorizem & 23 & 330 & 9 \\
\hline & psihološka dejavnost in stres v SV & 18 & 257 & 7 \\
\hline \multirow{8}{*}{ Obrambne zadeve } & obrambna politika & 10 & 157 & 4 \\
\hline & vključevanje v Nato in EU & 4 & 87 & 2 \\
\hline & obrambno načrtovanje & 9 & 410 & 12 \\
\hline & MVS in obrambna diplomacija & 2 & 41 & 1 \\
\hline & teorija (organizacije, menedžmenta idr.) & 28 & 483 & 14 \\
\hline & nabavna logistika & 1 & 26 & 1 \\
\hline & Evropska obrambna agencija (EDA) & 0 & 0 & 0 \\
\hline & kartografija in GIS & 0 & 0 & 0 \\
\hline Drugo & uvodniki ${ }^{12}$ & 9 & 27 & 1 \\
\hline Skupaj & & 194 & 3493 & \\
\hline
\end{tabular}

Kakovost in strokovnost publikacije na zanimiv način kažejo tudi njeni avtorji in njihovo število. Seveda bi za podrobno proučitev tega potrebovali bistveno več podatkov, do katerih se s preprosto analizo člankov ni dalo priti. Pridobivanje podatkov o izobrazbi, činih in strokovnih ter akademskih nazivih avtorjev ne nazadnje niti ni bil naš cilj. V tem delu analize nas je predvsem zanimalo, iz katerega dela obrambne strukture prihajajo avtorji in kakšna je frekvenca pisanja po avtorjih. Ugotovimo, da so avtorji člankov do leta 2004 predvsem posamezniki, nato pa se pojavljajo tudi članki z dvema avtorjema ali več. Povedano drugače, pri 194 prispevkih je v desetih letih sodelovalo 237 avtorjev $^{13}$. Pri 166 prispevkih ali 86 odstotkih je bil avtor en

${ }^{11}$ Določitev področij znotraj vojaških in obrambnih zadev je izvedena po štabnih funkcijah $v$ vojski ter $v$ kombinaciji s funkcijskimi področji ali projekti v SV oziroma MORS.

12 Uvodniki praviloma ne izpolnjujejo vseh metodoloških zahtev kot članki, zato jih označujemo s prispevki. V tem pregledu smo jih zajeli zgolj zaradi celovitosti prikaza obsega izdaj.

13 Število vseh sodelujočih je seštevek samostojnih avtorjev in soavtorjev po člankih. Vseh je 155, od tega 30 žensk, vključno z 12 častnicami oz. višjimi vojaškimi uslužbenkami. 
sam, pri preostalih 28 člankih pa je sodelovalo skupaj 71 piscev. Dobri dve tretjini ali 69 odstotkov jih prihaja iz MO in SV, preostalih 31 odstotkov pa je zunanjih. Iz tabele 4 ugotovimo tudi, da je delež avtorjev iz tujine sorazmerno majhen, le triodstoten. Tuji avtorji se pojavljajo v zadnjih dveh letih in pišejo o terorizmu in protiterorizmu. Delež slovenskih avtorjev, ki niso iz MO in SV, pa se v zadnjih treh letih povečuje, kar kaže na to, da se Bilten SV vendarle prebija v širšo strokovno javnost. Krog piscev se v devetem (2007) in desetem letniku (2008) približuje številu 50, kar je zelo spodbudno. Če smo prej zapisali, da so pisci člankov za Bilten SV pretežno samostojni avtorji, podatki iz naslednje tabele kažejo, da stopnja sodelovanja pri nastajanju člankov vendarle ni tako slaba. Snovanje skupnih člankov je tako lahko dobra podlaga za spodbujanje skupinskega, zlasti vojaškostrokovnega in znanstvenoraziskovalnega dela. Člani uredniških odborov poudarjajo, da je bil v preteklosti ključni izziv v pridobivanju avtorjev in širjenju kroga sodelujočih ter $\mathrm{v}$ preseganju strahu pred strokovnim in še bolj znanstvenim pisanjem. Preseganje tega je bilo velikokrat močnejše od želje po publiciranju znanja in praktičnih izkušenj. Uredništva so si posebej prizadevala za širjenje vedenja o metodologiji in slogu pisanja strokovnih ter drugih člankov. V ta namen je bilo izdelanih več napotkov za pisanje in celo Navodilo za izdelavo Biltena $\mathrm{SV}^{14}$.

\begin{tabular}{|c|c|c|c|c|c|c|c|}
\hline \multirow{14}{*}{$\begin{array}{r}\text { Tabela 4: } \\
\text { Struktura } \\
\text { avtorjev } \\
\text { prispevkov V } \\
\text { Biltenu SV }\end{array}$} & Letnik & $\begin{array}{c}\text { Število } \\
\text { prispevkov }\end{array}$ & $\begin{array}{l}\text { Skupaj } \\
\text { avtorjev }\end{array}$ & \multicolumn{2}{|c|}{ Avtorji iz MO } & \multicolumn{2}{|c|}{ Drugi avtorji } \\
\hline & & & & SV & Drugi & Domači & Tuji \\
\hline & 1 (1999) & 10 & 10 & 10 & 0 & 0 & 0 \\
\hline & $2(2000)$ & 16 & 17 & 17 & 0 & 0 & 0 \\
\hline & $3(2001)$ & 11 & 13 & 12 & 0 & 1 & 0 \\
\hline & $4(2002)$ & 11 & 12 & 11 & 0 & 1 & 0 \\
\hline & $5(2003)$ & 18 & 20 & 19 & 1 & 0 & 0 \\
\hline & $6(2004)$ & 6 & 6 & 6 & 0 & 0 & 0 \\
\hline & $7(2005)$ & 13 & 17 & 17 & 0 & 0 & 0 \\
\hline & $8(2006)$ & 39 & 47 & 20 & 6 & 21 & 0 \\
\hline & $9(2007)$ & 32 & 45 & 26 & 1 & 14 & 4 \\
\hline & $10(2008)$ & 38 & 50 & 16 & 0 & 31 & 3 \\
\hline & Skupaj & 194 & $237^{15}$ & 154 & 9 & 67 & 7 \\
\hline & \multicolumn{3}{|c|}{ Odstotki glede na vse avtorje } & 65 & 3,8 & 28,2 & 3,0 \\
\hline
\end{tabular}

\footnotetext{
${ }_{14}$ Avtor Navodila za izdelavo Biltena Slovenske vojske, ki je bilo izdano leta 1999, je podpolkovnik Evgen Primožič, sedanji odgovorni urednik. Navodilo je preklicano z izdajo novega Navodila za pripravo in izdajo periodičnih publikacij št. 0070-4, ki ga je 7. 5. 2007 podpisal minister za obrambo.

${ }_{15}$ Da bi se izognili nesporazumu, poudarjamo, da je v desetih letih pri 194 prispevkih sodelovalo 155 avtorjev.
} 
Višji vojaški uslužbenec dr. Denis Čaleta je avtor z največ objavljenimi članki (9), prav tako je avtor z največ članki, ki prihaja iz SV, iz upravnega dela MO je to mag. Robert Masten (3 članki), zunanja avtorica z največ članki (4) pa je prof. dr. Ljubica Jelušič. V tabeli 5 je prikazan pregled avtorjev po številu prispevkov ne glede na to, ali so bili samostojni ali se pojavljajo kot soavtorji. Ugotovimo, da je 114 avtorjev objavilo po en prispevek, preostalih 41 sodelavcev pa se pojavlja z dvema ali več prispevki.

Tabela 5: Pregled avtorjev glede na število objavljenih prispevkov od 1999 do 2008

\begin{tabular}{|l|l|l|l|l|l|l|l|}
\hline \multirow{2}{*}{$\begin{array}{l}\text { Število vseh } \\
\text { člankov }\end{array}$} & \multirow{2}{*}{$\begin{array}{l}\text { Število vseh } \\
\text { avtorjev }\end{array}$} & \multicolumn{5}{|c|}{ Število avtorjev glede na število objavljenih prispevkov } \\
\cline { 3 - 10 } & & 1 & 2 & 3 & 4 & 5 & več kot 5 \\
\hline 194 & 155 & 114 & 25 & 6 & 4 & 3 & 3 \\
\hline
\end{tabular}

Seveda analiza ne bi bila popolna, če ne bi vsaj delno predstavili še naklade in stroškovnega vidika izhajanja ${ }^{16}$. Leta 2006 je bila naklada 400 izvodov, strošek tiskanja na številko pa je bil 2,49 evra, tako da so bili skupni letni stroški 3990 evrov. Leta 2007 je bila naklada 470 izvodov, pri čemer je bil strošek na številko od 3,61 do 4,33 evra, za tri številke pa so bili stroški 5595 evrov. ${ }^{17}$ Naklada za izdane tri številke leta 2008 je bila 500 izvodov, pri čemer je strošek na številko od 3,32 do 5,39 evra, tako da so bili dosedanji letošnji stroški 6170 evrov. Predstavljena analiza izhajanja Biltena SV v preteklih desetih letih kaže, da se je publikacija uveljavila kot strokovno glasilo Slovenske vojske. Nekatere začetne težave in uresničeni ter še nedoseženi izzivi so razvidni tudi iz prikazanih statistik. Statistike pa ne morejo prikazati volje in volonterstva $\mathrm{v}$ pozitivnem pomenu besed, ki so ju v pripravo številk vlagali odgovorni uredniki in člani uredniških odborov. Ti so kljub temu, da so vanje bili imenovani z ukazi, to opravljali z veliko dobre volje in entuziazma. Zato čutim dolžnost za zahvalo vsem, ki so sooblikovali Bilten, še posebej tistim, ki so si prizadevali, da je preživel, se ohranil in v zadnjih letih dvignil »naklado« ter se usmeril tja, kamor kot podobne publikacije drugih držav v zavezništvu spada. »Znanje zmaguje« je slogan Biltena SV, ki je gotovo aktualen tudi za naprej. Toliko bolj, ker sta znanje in strokovnost temeljni odliki sodobnega vojaškega profesionalca in spreminjanja vojsk. Zapišimo drugače: Vojska, ki svojega znanja ne zna publicirati, ga težko uveljavi tudi v praksi. Tako je jasnejše spoznanje, da je treba po desetih letih izhajanja Biltena SV še pogumneje stopati naprej.

\section{UREDNIŠKA POLITIKA - STRATEGIJA LETA 2008}

7. novembra 2007 se je na pogovor pri meni najavil odgovorni urednik uredniškega odbora Biltena SV in me seznanil z določilom Navodila za pripravo in izdajanje

\footnotetext{
${ }^{16}$ Podatki o finančnih izdatkih za Bilten SV pred letom 2006 niso bili dosegljivi.

${ }_{17}$ Bilten SV 9-4 (2007) je bil natisnjen leta 2008, zato stroški niso vključeni za leto 2007.
} 
periodičnih publikacij Slovenske vojske, po katerem sem po funkciji določen za glavnega urednika Biltena SV, ter z odločitvijo načelnika GŠSV, da se oblikuje novo »uredništvo«. Seznanitev s stanjem in načinom delovanja uredniškega odbora, nekaterimi dosežki, pa tudi težavami, je kazala na to, da gre za nov izziv, ki se ga je treba lotiti z vso resnostjo. Odgovornemu uredniku sem, tako kot on pred tem meni, naložil vrsto nalog, ki so bile povezane z oblikovanjem in začetkom delovanja novega uredniškega odbora, in sicer od poročila o delovanju v preteklem obdobju do idej za nov program dela, poslovnik in seveda novo sestavo ekipe, ki bo, še vedno predvsem na prostovoljni podlagi, reševala številna vprašanja ob izhajanju te publikacije. Reševanje dodeljenih nalog in podrobnejše seznanjanje z razmerami je trajalo kar nekaj časa. V vmesnem obdobju je bil opravljen tudi obisk v Službi za založništvo MO, poleg tega smo ugotovili, kako potekata načrtovanje in organizacijska podpora v pristojni notranji organizacijski enoti za založništvo in izdajateljstvo PDRIU. 11. februarja 2008 je bil s sklepom načelnika Generalštaba Slovenske vojske imenovan nov uredniški odbor, 20. februarja pa je bila opravljena tudi primopredaja med prejšnjim in novim uredniškim odborom. Glede na to, da je bila v izdajateljskih ciljih za leto 2008 predvidena izdaja štirih številk, za pripravo in izdajo posamezne številke pa so ob zbranih prispevkih potrebni skoraj trije meseci, je razumljivo, da je bilo temu treba prilagoditi tudi uredniško vnemo in aktivnosti za doseganje postavljenih ciljev. Navedene ugotovitve in pripravljenost članov uredniškega odbora za konstruktivno reševanje ter timsko delo so premagali marsikatero oviro v službah in postopkih za pripravo in izdajo publikacij, ki jih vodijo pristojne organizacijske enote v MO. Ko smo se v uredniškem odboru začeli pogovarjati tudi o uresničevanju strategije, ki smo jo zapisali v Programu dela, je bilo sklenjeno, da jo glavni urednik predstavi v zadnji številki letnika 2008 (10/Št. 4), ko naj bi bil Bilten SV predstavljen javnosti tudi v novi grafični podobi. Uredniški odbor je glavna določila uredniške politike zapisal v Program dela uredniškega odbora Biltena SV, ki ga je sprejel na drugi seji 7. marca 2008. Zaradi nekaterih že navedenih nejasnosti pri nastajanju je v programu uredniška politika označena kot strategija. Tako si je uredniški odbor zastavil cilj »ostati uspešen, kakovosten in odprt za vse, ki želijo sodelovati pri pisanju prispevkov« (Program 2008: I/3. odst.). Povsem jasno je opredeljen temeljni cilj za leto 2008, ki je usmerjen v dvig klasifikacije publikacije skladno s habilitacijskimi merili Univerze v Ljubljani in Univerze v Mariboru, in sicer iz sedanje četrte skupine revij v tretjo. Pomembna je tudi usmeritev uredniškega odbora k razvoju vojaške stroke in vojaških znanosti z objavljanjem člankov, ki bodo na teh področjih predstavljali dodano vrednost sedanjim spoznanjem. Tem ciljem je bil prilagojen tudi akcijski načrt za leto 2008 (Program dela, 2008). Ta je na eni strani usmerjen v doseganje letošnjega cilja - izdajo štirih številk in tisk manjkajoče številke iz leta 2007, po drugi pa ima vrsto nalog, povezanih s prej omenjenimi cilji, ki jih bomo pojasnili v nadaljevanju. Lahko zapišemo, da je sedmi uredniški odbor Biltena SV v dosedanjem delu uspešno uresničil obe vrsti nalog. V ospredju so bile tiste, ki so zagotavljale izdajo načrtovanih številk v letošnjem letu. Na začetku je poseben izziv predstavljalo organiziranje uredniškega odbora. Skupno oblikovanje poslovnika in programa dela je vzelo precej časa, saj smo zanju porabili kar dve seji. Pozitivni učinki takšnega skupinskega pristopa pa so bili kmalu opazni, saj sedaj uredniški 
odbor deluje kot dobra in uigrana ekipa, v kateri ne manjka različnosti in kritičnosti. V poslovnik smo zapisali tudi nekaj o posebnostih vloge glavnega in odgovornega urednika, odločanju na sejah ter seveda številne procesne določbe.

V uredniškem odboru prisegamo na to, da je sodelovanje pri njegovem delu dobra priložnost za učenje. Tega je pri snovanju posameznih številk, zlasti tematskih, veliko. Če upoštevamo še reševanje recenzij in postopke selekcije prispevkov, lahko zapišemo, da tudi strokovnih izzivov pri delu uredništva ne manjka. Posamezni člani se preizkušajo kot »gostujoči uredniki«, to pomeni, da urejajo posamezne številke. Ko bodo dokončno uspešno razmejena opravila med odgovornim, gostujočim in tehničnim urednikom, bo stresnih situacij pri lovljenju načrtovanih rokov bistveno manj. Na tem področju je eden ključnih izzivov, ne le za uredniški odbor, temveč tudi širše, uveljavitev uspešne metodologije in postopkov pri ustvarjanju publikacije, pri katerih bo čim manj izgube časa in nepotrebnega birokratiziranja ali skrivanja za nefleksibilnimi postopki pristojnih organizacijskih enot, ki so zadolžene za podporo uredniškim odborom ${ }^{18}$.

Dosežki in napake so spremljevalci vsakega dela, tudi uredniškega. Zato je treba omeniti še problem in pridobljeno izkušnjo, s katero smo se srečali v uredniškem odboru ob odzivu in kritiki na prispevek, objavljen v četrti številki lanskega letnika $\left(9 /\right.$ Št. $\left.4^{19}\right)$. Avtorji smo seveda odgovorni za zapisano, s tem izražamo tudi svojo strokovno in jezikovno sposobnost. Pri omenjenem primeru pa smo ugotovili, da lahko avtorji z napačnim, metodološko neustreznim ali površnim navajanjem škodo povzročimo tudi tistim, ki jih navajamo. Primer je utrdil prepričanje, da je pri prihodnjem snovanju številk Biltena SV treba v celoti upoštevati zahteve recenzije in čas zanjo.

Izzivi, ki čakajo uredniški odbor Biltena SV do konca leta 2008, so povezani z načrtovanjem izdaje publikacij za leto 2009, pa tudi še z nedokončanimi organizacijskimi nalogami iz letošnjega programa. V mislih imamo načrtovano predlaganje sprememb in dopolnitev Navodila za pripravo in izdajanje periodičnih publikacij, uresničitev ideje za oblikovanje uredniškega sveta namesto razširjenega uredniškega odbora, sodelovanje z ustanovami in publikacijami v tujini ter ne nazadnje dokončno oblikovanje spletne strani $\mathrm{v}$ slovenskem in angleškem jeziku ter tovrstnega stika z bralstvom. Novi uredniški odbor je dobil pomembne izkušnje v pripravah vseh štirih letošnjih številk. Vsaka zase je bila svojstven preizkus organizacijske zrelosti uredništva. Še največ neznank se je pojavilo pri snovanju prve tematske številke, posvečene izobraževanju častnikov SV v prihodnosti, eni najbolj »vročih« tem, s strokovno ter organizacijsko najbolj različnimi pogledi. Strokovno še zahtevnejša je bila letošnja druga tematska številka, v kateri smo se soočili z vso nujnostjo recenzij pri tematiki obvladovanja stresa v SV. Škoda, ker nekaterih prispevkov

${ }_{18}$ Za takšen primer bi lahko označili tudi zaplete pri pripravi nove grafične podobe, kjer nismo uspeli premagati vseh ovir na poti do želenega cilja.

19 Več o tem v Polemike, odgovori in komentarji http://www.mors.si/index.php?id=223 1.10.08) ter v pripombah in popravkih ppk. Mojce Pešec http://www.mors.si/fileadmin/mors/pdf/Bilten_SV/Bilten_odgovor_Jun08.pdf 1.10.08) 
nismo prevedli ali jih celo napisali v tujem jeziku in tako še bolj odprli revije v mednarodno okolje. To nam je uspelo pri tretji tematski številki (10/Št. 3), posvečeni protiteroristični tematiki in prizadevanjem na tem področju v Jugovzhodni Evropi. S to tematsko številko Bilten SV dokončno vstopa v mednarodni prostor ${ }^{20}$. Kar nekaj novosti je bilo pri tem doseženih; poudarjam pristop, s katerim so sestavki prevedeni $\mathrm{v}$ angleški jezik. $\mathrm{S}$ tem je ta publikacija uspešno podpirala posebno konferenco o protiterorizmu, ki jo je že drugič organizirala Slovenija. Četrta številka, ki je posvečena deseti obletnici izhajanja, ima dodatno kakovost v izbranih prispevkih, saj sta temu gostujoča urednica in uredniški odbor namenila posebno pozornost. Pri tretji in četrti številki smo se srečali tudi s primeri, da so nekateri avtorji odstopili od objave, ker so bile zanje pripombe recenzentov »prehude «.

\section{VIZIJA, STRATEGIJA IN PRIHODNJI IZZIVI ZA BILTEN SV}

Vizija uredniškega odbora Biltena SV je doseči takšno raven kakovosti in prepoznavnosti člankov in publikacije, da bo Bilten uvrščen v tretjo skupino publikacij po habilitacijskih merilih Univerze v Ljubljani in Univerze v Mariboru, vsebine pa bodo prispevale $\mathrm{k}$ razvoju obrambno-vojaške znanosti oziroma stroke skladno z opredeljenimi potrebami izdajatelja. Pri doseganju vizije je kot pot do cilja pomembna strategija za njeno uresničitev. Naša strategija je izboljšanje kakovosti publikacije in s tem dvig ravni njene klasifikacije v tretjo skupino, kar je mogoče $\mathrm{z}$ racionalnim načrtovanjem, premišljeno izbiro vsebin in avtorjev, uvedbo recenzij in doslednim spoštovanjem anonimnega recenzentskega postopka. Načrtno organizacijsko in tehnično delo pri snovanju posameznih številk ter nadgradnja dela glavnega in tehničnega urednika oziroma uredništva kot celote so pomembni za uspeh, kar je potrdila tudi letošnja izkušnja. Pomemben izziv je tudi uveljavitev sodelovanja $\mathrm{z}$ domačimi in tujimi strokovnimi ter znanstvenimi organizacijami in povezava $\mathrm{z}$ njihovimi publikacijami. To omogoča objavljanje prispevkov tujih in gostujočih avtorjev, hkrati pa podpira možnosti za objavljanje prispevkov avtorjev iz SV ter MO v tujih publikacijah. V uredniškem odboru se zavedamo, da prehod publikacije $\mathrm{V}$ višjo klasifikacijsko skupino ni preprost in odvisen samo od dela uredništva, saj zahteva predstavitev znanja v prispevkih, strokovni in vedno bolj tudi znanstveni pristop k pisanju, uporabo ustreznega strokovnega jezika ter ne nazadnje spoštovanje raziskovalne metodologije pri oblikovanju prispevkov. $\mathrm{Z}$ navedenim lahko Bilten SV pomembno prispeva tudi k razvoju bodočih strokovnjakov in znanstvenikov v vojski ter na MO.

Vprašanje širjenja kroga sodelavcev je tesno povezano z dvigom kakovosti, čeprav je v navideznem nasprotju, ker se s širjenjem količine običajno zmanjšuje kakovost. Navedimo, da je trenutno v SV zaposlenih deset doktorjev znanosti, število magistrov pa bo kmalu večje od števila polkovnikov. Če k temu dodamo še potencial upravnega dela MO in zunanjih sodelavcev, se odpira vprašanje, s čim privabiti tiste, ki znajo, k ustvarjanju in sodelovanju v publikaciji. Profesionalna publikacija ima tudi nekaj

${ }^{20}$ Že tematska številka 9/Št. 2 o protiterorizmu iz leta 2007 je doživela zelo ugoden odziv, čeprav je bila izdana po konferenci, ki je bila na Igu pri Ljubljani septembra 2007, in posredovana na številne tuje naslove. 
povsem materialnih izzivov, povezanih s finančnim vrednotenjem člankov. Ker je v nekaterih publikacijah, ki jih izdaja MO, ta praksa že uveljavljena, lahko upamo, da jo bomo lahko uveljavili tudi v Biltenu SV. Ali je to pot za prehod publikacije iz volonterstva $\mathrm{v}$ profesionalizem, je vprašanje, ki ima svoje zagovornike, pa tudi nasprotnike.

Kljub »vojaški organiziranosti« uredniškega odbora Biltena v njegovem delovanju prisegamo na odprtost in konstruktivnost. To pa pomeni tudi odprtost za pobude iz ožjega in širšega okolja. Širjenje okolja Biltena SV pa zahteva zagotovitev dostopnosti prek spletne strani in začetek komuniciranja s strokovno javnostjo po internetu. Tu smo gotovo še na začetku, čeprav smo bili letos zelo veseli, da nam je uspelo za Bilten SV dobiti prostor na spletnih straneh MO (htpp://www.mors.si/index. php?id=213). Verjamemo, da bomo na tej podlagi uspeli v prihodnosti oblikovati in širiti tudi mrežo sodelavcev, najprej v Sloveniji in zatem še v mednarodnem okolju.

Poseben strokovni izziv za uredništvo in avtorje prispevkov je povezan z vprašanjem zagotavljanja ravnotežja med teorijo in prakso. Pogled in primerjave s podobnimi publikacijami v tujini zgovorno kažejo, da je pri takšnih publikacijah usmeritev v empiričnost primarna, pri čemer teoretične podlage služijo kot izhodišča ali podpora za preverjanje v praksi. Izdajatelja gotovo zanima predvsem praktična uporabnost publiciranega znanja in spoznanj. Lahko bi seveda sklepali tudi drugače, ker je Bilten SV opredeljen tudi kot informativna publikacija, namenjena izobraževanju. Pri veščinskem vojaškem učenju je praktični del seveda zelo pomemben, kar pa se spremeni pri splošnem vojaškostrokovnem izobraževanju, predvsem častnikov kot pripadnikov vojaške profesije.

Sklep Bilten SV je v desetih letih svojega izhajanja prehodil zanimivo pot volonterstva in vztrajnosti urednikov. Število publikacij in avtorjev se je postopno širilo ter v zadnjih treh letih doseglo zavidljivo raven. To kaže, da se je Bilten utrdil in postal pomemben vojaškostrokovni glasnik, ne le Slovenske vojske, temveč tudi širše. K temu je pomembno prispevalo odpiranje uredništva navzven in pridobivanje avtorjev iz tujine. Tak primer je bil v letih 2007 in 2008 povezan z mednarodno konferenco o protiterorizmu v Sloveniji in izidom posebnih tematskih številk. Tako je Bilten prestopil nacionalne okvire in presegel dilemo, ali pisati in objavljati zgolj v slovenskem jeziku oziroma ali so čas in okoliščine zreli za objavo člankov v jezikih gostujočih avtorjev. Sedmi uredniški odbor je zaznal in sprejel izzive, ki so pred naslednjim desetletjem publikacije. Ti izzivi so povezani z nadaljnjim odpiranjem publikacije v mednarodno okolje, prehodom na internetni medij, širjenjem kroga sodelujočih ter dvigom strokovnosti in s tem kakovosti Biltena SV. Upam, da bo Bilten po desetih letih dobil novo grafično podobo, in če bodo doseženi tudi drugi cilji, lahko pričakujemo, da ga bodo pripadniki SV in tudi strokovna javnost v MO ter širšem obrambnem okolju brali in uporabljali kot izziv za svoje razmišljanje ali kritiko. Z navedenim lahko dosežemo tudi glavni cilj, ta pa je uvrstitev publikacije $\mathrm{v}$ višji klasifikacijski rang. Z odpiranjem v širši prostor, dvigom kakovosti prispevkov, 
njihovim ustreznim vrednotenjem in nagrajevanjem pa bo odprta pot do strokovne tekmovalnosti ter z njo do ustvarjalne vrednosti za Slovensko vojsko in obrambni sistem. Tako smo prepričani, da ni več daleč čas, ko bo uredniški odbor lahko spremenil svojo vlogo iz iskalca in nabiralca prispevkov $\mathrm{v}$ izbiralca oziroma selektorja vojaškostrokovnih besedil glede na njihovo kakovost in pomen.

\section{Literatura}

1. Generalštab Slovenske vojske, 2008: Namen in vloga uredniškega odbora, Dostopno na http://www.mors.si/index.php?id=214 (1. 10. 2008).

2. Generalštab Slovenske vojske, 2008: Polemike, odgovori in komentarji. Dostopno na http://www.mors.si/index.php?id=223 (1. 10. 2008).

3. Generalštab Slovenske vojske, 2008: Poročilo o delu Uredniškega odbora Biltena SV v obdobju 2006-2007.

4. Generalštab Slovenske vojske, 2008: Sklep o imenovanju Uredniškega odbora Biltena Slovenske vojske.

5. Ministrstvo za obrambo, 2007: Navodilo za pripravo in izdajanje periodičnih publikacij Slovenske vojske. Dostopno na http://www.mors.si/fileadmin/mors/pdf/Bilten_SV/ Navodilo_pripravo_izdajanje_pubikacij_07_05_07.pdf(1. 10. 2008).

6. Ministrstvo za obrambo, 2007: Pravilnik o založniški in filmski dejavnosti v MO RS. Dokument MO, šifra 811-11-7/2005-34 z dne 24. 7. 2006.

7. Ministrstvo za obrambo, 1999: Navodilo za izdelavo Biltena Slovenske vojske. Dokument MO številka 017-04-21/98 z dne 17. 3. 1999.

8. Uroš TRINKO, Alojz ŠTEINER, 2008: Analiza Biltenov SV 1999-2008.

9. Uredniški odbor Biltena SV, 2008: Poslovnik uredniškega odbora za pripravo in izdajo Biltena Slovenske vojske. Dostopno na http://www.mors.si/fileadmin/mors/pdf/Bilten_SVI poslovnik_uredn_odbora.pdf(1.10.2008).

10. Uredniški odbor Biltena SV, 2008: Program dela uredniškega odbora Biltena SV. Dostopno na http://www.mors.si/fileadmin/mors/pdf/Bilten_SV/nacrt_dela_ urednistva_08.pdf (1.10.2008). 


\section{POPOTNICA BILTENU SLOVENSKE VOJSKE V DRUGO DESETLETJE}

Prenovljena številka strokovne revije Bilten Slovenske vojske je namenjena vprašanju slovenske zavezanosti mirnemu reševanju konfliktov, kar se mi kot vrhovnemu poveljniku obrambnih sil Republike Slovenije zdi ne samo potrebno, temveč tudi nujno. Za to vidim kar nekaj razlogov. Zgodovinske izkušnje Slovenk in Slovencev niso bile prijetne, če govorimo o ohranitvi narodove identitete, izražene v jeziku ter kulturnem in narodnem izročilu. Kljub različnim pojavnim oblikam raznarodovalnih ukrepov mnogih tujih oblasti je našim prednikom uspelo z veliko modrosti, globoke narodne zavesti in tudi politične spretnosti ohraniti slovenski narod. Kako pomembno je dosledno upoštevanje določil mednarodnega prava tudi v kriznih razmerah ali celo v vojni, se je pokazalo leta 1991. Slovenija je zmagala v vojni, a ne le v vojaškem smislu, temveč je z upoštevanjem vseh pravnih norm hitro postala prepoznavna, sicer kot mlada, vendar na visokih pravnih in moralnih načelih utemeljena evropska demokracija. Vojne izkušnje iz leta 1991 so še povečale občutek slovenskega naroda za jasno zavračanje uporabe sile pri reševanju kakršnih koli konfliktov.

Zato je moje zadovoljstvo ob povabilu k pisanju na temo Slovenci v službi miru toliko večje. Deloma tudi zaradi dejstva, da sem velik del svojega poklicnega življenja, in sicer od leta 1992 do 2005, preživel v OZN. Sprva kot veleposlanik RS, nato kot pomočnik generalnega sekretarja OZN. V obeh funkcijah sem imel precej opravka z mirovnimi operacijami. Mirovne operacije OZN so se takrat razmahnile in doživele velik razvoj, na drugi strani pa tudi bridka razočaranja ter trenutke globoke skepse. Vendar so se razvijale naprej, vse do današnjega obsega.

Tema Biltena je predstavljena resnično poglobljeno, znanstveno, teoretično in praktično, s strateške in taktične ravni, upoštevajoč evolutivne in transformacijske značilnosti mirovnih operacij ter izhajajoč iz zgodovinskih izkušenj. Najpristojnejši avtorji $\mathrm{v}$ slovenskem strokovnem prostoru so osvetlili pomembne konceptualne 
spremembe na področju mirovnih operacij, ki so posledica številnih dejavnikov, predvsem pa pomembnih geopolitičnih sprememb v svetu. Ne smemo zanemariti vse večjega sodelovanja regionalnih organizacij pri uresničevanju mirovnih operacij, kar je posredno povzročilo drugačno razumevanje têrmina mirovna operacija in odprlo strokovne razprave tako na področju terminologije kot pri tehničnem izpolnjevanju obveznosti, pa vse do vprašanja nujnosti predhodnega mandata OZN. Te pomanjkljivosti se kažejo tudi v slovenskem prostoru, v katerem bo v prihodnje treba čim prej opraviti poglobljeno strokovno razpravo in poenotiti razumevanje tako v strukturah Slovenske vojske kot v širšem obrambno-varnostnem sistemu. Pri tem je mogoče uvodni in predvsem bolj teoretični del Biltena razumeti kot pomemben prispevek $\mathrm{k}$ temu pogledu.

Del prispevkov omogoča zanimiv zgodovinski vpogled v sodelovanje Slovencev in pozneje Slovenk v različnih mirovnih prizadevanjih posameznih velesil in mednarodnih organizacij. Čeprav je vojaško posredovanje evropskih sil na otoku Kreti leta 1897 težko razumeti kot mirovno operacijo, je bil vsaj za nekaj časa dosežen cilj, ki je še vedno v ospredju sodobnih prizadevanj mednarodne skupnosti na tem področju. Posredovanje je namreč zagotovilo premirje med strankama v spopadu ter brez nepotrebnih žrtev omogočilo diplomatsko reševanje spora na otoku. Zaupanje najvišjih političnih in vojaških oblasti v Avstro-Ogrski, ki ga je takrat doživel II. bataljon 87. celjskega pehotnega polka, je bilo res posebno. Posebno tudi zato, ker so to vojaško enoto sestavljali predvsem Slovenci in ker ji je poveljeval Slovenec tudi ob namestitvi na Kreto. Kljub temu je treba poudariti, da je takšno razmišljanje nekonvencionalno, saj ob proučevanju literature o mirovnih operacijah ugotovimo, da se te začenjajo omenjati okrog leta 1919, in sicer z mirovnimi konferencami po koncu prve svetovne vojne in urejanjem različnih mejnih vprašanj v Evropi, z različnimi plebisciti in drugimi dogodki, ki so poleg političnega in drugega diplomatskega delovanja zahtevali tudi zaščito varnosti, zaradi česar so sledile vojaške operacije, ki so bile namenjene prav temu.

Zgodovina veliko govori o mirovnih operacijah, ki so bile namenjene vzdrževanju premirja. Pri teh operacijah je šlo za postavitev koalicijskih sil na območje, na katerem je premirje že obstajalo in ga je bilo treba vzdrževati med dobro organiziranimi in discipliniranimi oboroženimi silami. Danes je položaj oboroženih sil precej drugačen, zaradi česar je treba pogledati vso zgodovino in vse vidike mednarodnega vojaškega delovanja, ki nima značaja oboroženega boja, temveč vojaške prisotnosti $\mathrm{z}$ različnimi vidiki uporabe vojaške sile in seveda $\mathrm{z}$ vedno prisotno pripravljenostjo ter sposobnostjo mirovnih sil, da so učinkovite $\mathrm{v}$ samoobrambi in pripravljene uporabiti orožje tudi za izpolnitev svojega mandata. Če danes s tega vidika utemeljeno gledamo na mirovne operacije, je popolnoma jasno, da je treba poznati zgodovino in presoditi, kaj se lahko naučimo iz izkušenj in kako je treba razmišljati o sedanjosti.

O sedanjosti pa je seveda treba razmišljati, kajti če pogledamo stanje današnjih mirovnih operacij, vidimo, kako pomembna je ta vojaška dejavnost za sodobni svet. Zadržal se bom le pri OZN, ki je s stališča mirovnih operacij danes najpomembnejša 
organizacija. V mirovnih operacijah v okviru OZN deluje približno 140.000 vojakov. Nobena vojaška sila nima tolikšnega števila uniformiranega osebja, dejavnega $\mathrm{v}$ tujini. Ti ljudje so razporejeni v osemnajstih trenutno aktivnih mirovnih operacijah, vsaka pa stane organizacijo sedem milijard dolarjev. To je največji del sredstev, ki jih porabi OZN, a je ta poraba še vedno majhna v primerjavi z drugimi vrstami vojaškega nameščanja zunaj OZN, ki nimajo značaja mirovnih operacij.

Mirovne operacije so postale zelo vsestranske. Zadnje, uvedene v Afriki (Darfur, Čad, Centralnoafriška republika), že na začetku spadajo med najzahtevnejše. Iz tega je mogoče sklepati, da se zahtevnost mirovnih operacij povečuje, s čimer raste tudi stopnja tveganja. Leta 2007 je življenje izgubilo 67 pripadnikov mirovnih operacij OZN. Če gledamo po posameznih operacijah, vidimo, da jih je bilo tega leta samo v Libanonu šest. Libanon je, odkar obstajajo mirovne operacije, eno izmed najnevarnejših območij, čeprav je danes nekoliko zunaj središča zanimanja. To lahko pripišemo dejstvu, da je tam aktivna mirovna operacija, zaradi katere se stanje sorazmernega miru bolje vzdržuje.

Mirovne operacije so nevarne in vsestranske. Vsestranske zato, ker v ospredju ni več le razmejitev vojskujočih se strani. Poleg klasičnih funkcij se v sodobnih mirovnih operacijah opravljajo tudi druge. Zagotavljanje varnega okolja za politično normalizacijo, humanitarno dejavnost in razvoj je celovita naloga, ki zahteva delovanje mirovnih sil daleč od vsakdanjih oblik vojaškega nameščanja. Ob tem se postavljajo različna vprašanja o usposabljanju in usposobljenosti mirovnih sil. Vprašati pa se je treba tudi, kako celovito obravnavati izkušnje iz dosedanjih mirovnih operacij in organizirati sistem poveljevanja, posebej še v organizacijah, kot je OZN, pri čemer je pomembno, da nacionalni kontingenti ne izgubijo svoje identitete. Torej obstajata dve liniji komunikacije, ena po poteh, ki jih določa mednarodna organizacija, in druga po tistih, ki jih določa nacionalni sistem oboroženih sil. Kako to uskladiti in doseči učinkovito delovanje, kako zagotoviti delovanje različnih kultur, pripadnikov in ravni usposobljenosti na način, ki bo omogočil uspešnost mirovne operacije? To so vselej velika vprašanja oziroma problemi.

V zadnjih letih je postalo aktualno vprašanje, ki kaže na zahtevnost sodobnih mirovnih operacij. Mirovne operacije imajo večkrat nalogo omogočiti okolje, v katerem se lahko izvedejo volitve, in pomagati pri uvedbi pravnega reda ter institucij, ki ta red vzdržujejo. Obe nalogi sta izjemno zahtevni. Vzpostavljanje varnega okolja za volitve v državi, kjer so komunikacije slabe, kjer ni tradicije volitev in kjer je z vsakim političnim dogodkom povezano nasilje, je izjemno težka naloga. Vzpostavljanje pravnega reda v okoljih, kjer ni takšne tradicije in ustrezne infrastrukture, je še težje. Pogosto se pri tem pojavi potreba po vključevanju civilne policije, ki ima v mirovnih operacijah zahtevne naloge. Civilna policija ima poleg težav, povezanih s prej omenjeno vsestranskostjo, še nekatere druge posebnosti. Treba se je prilagoditi lokalnemu okolju, in sicer tako, da omogoča učinkovito opravljanje policijskih nalog. Kako to zagotoviti v okolju, kot je na primer Haiti s svojo težko preteklostjo, kako v jezikovno zahtevnih okoljih, kot je bil do pred kratkim Vzhodni Timor, ali v drugih težavnih okoliščinah? 
Vse to so izjemno zahtevne naloge, ni pa veliko razumevanja za vse podrobnosti in težave, ki se pojavljajo ob njihovem uresničevanju. Mednarodna in politična javnost sta pogosto zadovoljni že z določitvijo mandata mirovni operaciji. S tem je za marsikoga vprašanje rešeno, saj je mandat določen in bo prišlo do nameščanja sil. Vendar pa se stvarno reševanje težav takrat šele začne. Šele takrat je očitno, kako malo lahko v kontekstu konkretne situacije pomenijo splošne resolucije Varnostnega sveta OZN in drugi akti, s katerimi se določajo mandati. Zato menim, da je nujen podroben pogled v izkušnje, tako iz oddaljene preteklosti kot tudi iz naše sedanjosti.

Pri govoru o civilni policiji je treba upoštevati tudi nekatere popolnoma človeške vidike, ki se pojavljajo pri vsaki mirovni operaciji. Nekoč sem z nekim zelo izkušenim voditeljem civilno-policijskih dejavnosti govoril o potrebi, da bi na misijo na Kosovo poslali dodatne policiste spomladi, ko zima mine in postanejo ljudje dejavnejši in se zato poveča obseg kriminala. Pojasnil mi je, da se ta težava ne pojavlja le na območju omenjene misije, temveč povsod po Evropi. Povsod se spomladi poveča število kriminalnih dejanj, zato je v tem času najtežje najti policiste, ki so pripravljeni zapustiti domovino, kjer jih bolj potrebujejo, in oditi v okolje misije, ki se ravno sooča s povečanimi potrebami. To omenjam zaradi razumevanja, da nameščanje mirovnih sil, tako vojaških kot civilno-policijskih, ni le stvar mandatov in vojaške organizacije, temveč včasih čisto osnovnih vprašanj, ki spremljajo družbeno dogajanje.

Omenil sem že, da je zgodovinski spomin zelo pomembna kategorija in sestavina razmišljanja o današnjih mirovnih operacijah. Za sklep bi dodal še eno misel. Menim, da je za vse države, zlasti za tiste, ki so pri sodelovanju v mirovnih operacijah nove, pomembno, kako organizirajo svoje znanje o mirovnih operacijah. To je znanje, ki se ne da naučiti iz knjig, napisanih na univerzah, temveč se pridobi s spremljanjem in skrbno analizo izkušenj. Zelo pomembno je, da se to znanje načrtno organizira, da se izkušnje načrtno zbirajo in analizirajo ter da iz tega postopoma izide doktrina, ki je potrebna, da se država, kot je Slovenija, ki je nov dejavnik pri izvajanju mirovnih operacij, dobro znajde in ustrezno definira svoj položaj in svojo vlogo v mednarodnih mirovnih operacijah. Za dosego tega cilja je za novo državo pomembno sodelovanje s tistimi državami, ki imajo daljši staž in bogatejše izkušnje pri mirovnih operacijah. Sosednja Avstrija je znana po tem, da ima v OZN enega najdaljših in najbolj zanimivih sistemov izkušenj iz mirovnih operacij. Avstrija je že od vstopa v OZN aktivna v številnih dejavnostih, povezanih z mirovnimi operacijami. Njeni vojaki so sodelovali v vrsti mirovnih operacij, tudi civilna policija je prisotna v marsikateri. Tako pridobljene izkušnje so izjemno dragocene, njihova uporaba pa nujna za uspeh načrtovanja in delovanja $\mathrm{v}$ prihodnjih mirovnih operacijah.

In ta prihodnost bo zapletena! V OZN so nekoč, ko je bilo pripadnikov mirovnih operacij okrog 80.000, mislili, da se ne da narediti nič več in je večje število pripadnikov nepredstavljivo. Danes je pripadnikov občutno več, razvoj bo najverjetneje še napredoval, razmere pa bodo še bolj zapletene. Ne želim pisati futuristično o stvareh, ki se še niso zgodile in o katerih ne bi bilo prav razpravljati. Želim pa opozoriti, da zgodovina mirovnih operacij še ni končana in da bo njihova prihodnost nevarna in zahtevna. 
Ravno tako želim ponovno poudariti pomen te številke Biltena Slovenske vojske, ki vstopa v novo desetletje, in izraziti zadovoljstvo, da mi je bilo omogočeno napisati nekaj misli. Posebej pa naj poudarim, da bom kot vrhovni poveljnik slovenskih obrambnih sil tudi $\mathrm{v}$ prihodnje posebno pozornost namenjal dosežkom prav na področju sodelovanja v mirovnih operacijah, še posebej pa me bodo zanimale njihove izkušnje. Avtorjem prispevkov v tej pomembni številki Biltena Slovenske vojske se zahvaljujem za njihov znanstveni in strokovni prispevek, vsem, ki so s slovensko zastavo na ramah že opravili pomembno delo v imenu Republike Slovenije, pa izrekam veliko spoštovanje $\mathrm{v}$ upanju na korektno izpolnjevanje obveznosti tudi $\mathrm{v}$ prihodnje. 


\section{A GUIDE-POST FOR THE SECOND DECADE OF THE BULLETIN OF THE SLOVENIAN ARMED FORCES}

This updated issue of the professional publication Bulletin of the Slovenian Armed Forces is dedicated to the question of the Slovenian commitment to finding peaceful solutions to conflicts. As Commander-in-Chief of the Defence Forces of the Republic of Slovenia, I find this subject not only necessary but also entirely essential. There are many reasons for this. The historical experience of the Slovenian people has not always been pleasant regarding the preservation of national identity, manifested in the language as well as in the cultural and national tradition. Despite different repressive and denationalising measures taken by many foreign authorities, our ancestors managed to preserve the Slovenian nation through much wisdom, deep national awareness and political skill. The importance of consistent compliance with the provisions of international law in crisis situations, including wars, was seen in 1991. Slovenia won the war, not only in a military sense but also by complying with all legal norms, thus soon becoming recognised as a young European democratic country founded on high legal and moral principles. The lessons of war in 1991 increased the resolve of the Slovenian people for clear rejection of the use of force in finding solutions to any kind of conflict.

For this reason, my pleasure at being invited to write about the topic of Slovenian people in the service of peace is that much greater, in part also due to the fact that I spent a large part of my professional life, from 1992 to 2005, working in the United Nations, first as the ambassador of the Republic of Slovenia, later as UN Assistant Secretary-General. In both functions I dealt with peacekeeping operations to a considerable extent. United Nations peacekeeping operations were in full swing at that time and underwent great development on the one hand, but also bitter disappointment and moments of deep doubt on the other. However, they continued to develop to the current extent. 
The topic of the Bulletin is presented in truly deep, scientific, theoretical and practical ways, from strategic and tactical levels, considering the evolutionary and transformational characteristics of peacekeeping operations, and deriving from historical experience. The most respected authors in the Slovenian professional field have thrown light upon important conceptual changes in the area of peacekeeping operations, which result from numerous factors, in particular from important geopolitical changes in the world. We must not disregard the increasing cooperation of regional organisations in the implementation of peacekeeping operations, which has indirectly brought about a different understanding of the term "peacekeeping operation" and opened technical discussions in the area of terminology as well as in the technical fulfilment of obligations, all the way to the question of the necessity of a preliminary UN mandate. These deficiencies can also be seen in Slovenia and point to the need for conducting a deep technical discussion as soon as possible and unifying the understanding of both the structure of the Slovenian Armed Forces and the broader defence and security system. The introductory and in particular the more theoretical parts of the Bulletin may be taken as important contributions in this regard.

Some of the articles offer interesting historical insight into the cooperation of Slovenian men, and later women, in various endeavours for peace launched by individual great powers and international organisations. Although it is difficult to understand the military intervention of European forces on the island Crete in 1897 as a peacekeeping operation, the objective which is still in the forefront of contemporary efforts of the international community in this area was achieved for at least some time. This intervention ensured an armistice between the parties involved in the conflict and enabled a diplomatic solution on the island without unnecessary victims. The confidence that the highest political and military authorities in the Austro-Hungarian Empire had in the $2^{\text {nd }}$ Battalion of the $87^{\text {th }}$ Infantry Regiment from Celje was truly special. This was particularly the case because the military unit was mainly composed of Slovenes, and at the time of deployment in Crete its commander was a Slovene as well. However, we need to emphasise that such thinking is unconventional. By studying the literature on peacekeeping operations we see that such operations were first mentioned around 1919 in connection with peace conferences after the end of World War I and with managing various border issues in Europe, different plebiscites and other situations which, besides political and other diplomatic action, also required the protection of security and were followed by military operations intended for this particular purpose.

History tells us much about peacekeeping operations intended to maintain truces. In these operations, coalition forces were deployed to an area in which a truce already existed and had to be maintained among well organised and disciplined armed forces. Today, the status of armed forces is quite different. We have to look at all of history and every aspect of international military engagement which is not armed combat by nature but a military presence with various aspects of employment of military force and the constant readiness and capability of peace forces to defend themselves 
effectively and be prepared to use weapons to fulfil their mandate. If today we see peacekeeping operations as valid in this respect, it is clear that we have to be familiar with history and evaluate what we can learn from past experience and how we are obliged to consider the present.

Of course, we must consider the present. If we look at the status of peacekeeping operations today, we see how important this military activity is for the modern world. I will only dwell upon the United Nations, which from the standpoint of peacekeeping operations is the most important organisation operating today. Approximately 140,000 soldiers participate in peacekeeping operations under the auspices of the United Nations. No other military force has that number of uniformed personnel operating abroad. These people are assigned to eighteen currently active peacekeeping operations, each costing the organisation about seven billion dollars. This is the largest component of the budget of the United Nations. However, this expenditure is small in comparison to other kinds of military deployment outside the $\mathrm{UN}$, to operations which are not peacekeeping operations by nature.

Peacekeeping operations have become very multidimensional. The latest such operations, established in Africa (Darfur, Chad, Central African Republic), have been among the most demanding from the very beginning. We can thus conclude that peacekeeping operations are becoming increasingly more complex, which also results in a higher degree of risk. In 2007, 67 members of UN peacekeeping operations lost their lives. Looking at individual operations we see that six people died in Lebanon alone that year. Ever since peacekeeping operations have been in existence, Lebanon has been one of the most dangerous areas. Today, however, it is somewhat outside the sphere of interest. This may be due to the fact that there is a peacekeeping operation active in the area, on account of which a state of relative peace can be better maintained.

Peacekeeping operations are both dangerous and multidimensional, multidimensional because they are no longer focused merely on keeping belligerent parties apart. Modern peacekeeping operations include both standard and supplemental functions. Providing a secure environment for political normalisation, humanitarian activity and development is a comprehensive task, requiring the engagement of peacekeeping forces in operations that are far from being common types of military deployment. This raises different questions about the training and competence of peacekeeping forces. We also have to ask ourselves how we can fully consider the lessons learned from previous peacekeeping operations and organise a system of command, particularly in organisations such as the United Nations, while at the same time making sure that national contingents do not lose their identity. There are thus two lines of communication, one through channels established by international organisations and the other through those established by national systems of armed forces. How to balance this and achieve efficient functioning? How to ensure the operation of different cultures, members and levels of competence in a way that facilitates the success of peacekeeping operations? These are always important questions to consider. 
In recent years the question of interest has pointed to the complexity of modern peacekeeping operations. Peacekeeping operations are frequently required to facilitate an environment in which elections can be conducted and assist in the establishment of a legal order and institutions to maintain that order. Both tasks are extremely demanding. The establishment of a safe environment for conducting elections in a country with poor communications, with no tradition of elections and with violence linked to every political event, is an extremely difficult task. The establishment of a legal order in areas with no such tradition or adequate infrastructure is even harder. There is often a need to include the civilian police, whose tasks in peacekeeping operations are very demanding. Civilian police have a number of other particularities besides problems connected to the aforementioned multidimensionality. It is necessary to adapt to the local environment in order to facilitate effective police performance. How to facilitate this in an environment such as Haiti, for example, with its difficult past? How to facilitate this in linguistically demanding environments such as East Timor until recently and in other difficult circumstances?

These are all extremely demanding tasks. However, there is not much understanding with regard to all the details and problems arising from their implementation. The international political community is often satisfied merely by defining the mandate of a peacekeeping operation. For many people this signifies the solution to the problem, considering that the mandate is defined and that the deployment of forces will occur. However, this is where real problem solving only begins. Only then does it become obvious what little meaning general resolutions of the United Nations Security Council and other acts by which mandates are defined have in the context of actual situations. Therefore, I am of the opinion that we have to take a detailed look at experience from the distant past as well as the present.

When speaking of the civilian police we also have to consider the fully human aspects that characterise every peacekeeping operation. Once I spoke to a very experienced leader of civilian police operations about the need to send additional police officers to the mission in Kosovo in the spring, when winter is over and people become more active, which also results in a higher crime rate. He explained that this is not only a problem in the area of this mission but elsewhere in Europe. In spring, the crime rate rises everywhere. Therefore it is difficult to find police officers during this time who are willing to leave their homeland, where they are most needed, and go to a mission area which is just then facing increased needs. I mention this to broaden understanding of the fact that the deployment of peacekeeping forces, both military and civilian police, is not only a matter of mandates and military organisation, but sometimes of the purely elementary questions that accompany social development.

I have already mentioned that memory of the past is a very important component of considering present peacekeeping operations. I would like to conclude with another thought. I believe the manner of organising the knowledge of peacekeeping operations is of great importance to all countries, especially those that are new to 
cooperating in peacekeeping operations. This knowledge cannot be gained from books written at universities, but only from monitoring and carefully analysing the previous experiences of others. It is very important that this knowledge be carefully organised, that these experiences be carefully gathered and analysed, and that a doctrine be developed gradually. This doctrine is required for a country like Slovenia, which is new at conducting peacekeeping operations, to be able to manage well and define its role in international peacekeeping operations properly. To achieve this objective, a new country must cooperate with those countries which have been conducting peacekeeping operations for a long time and therefore have a richer experience. The neighbouring Austria is known to have one of the longest and most interesting systems of experience in peacekeeping operations within the United Nations. Ever since it joined the UN, Austria has been active in numerous activities linked to peacekeeping operations. Its soldiers and the civilian police have participated in a number of peacekeeping operations. Experience gained in this way is of great value, and using this experience is necessary for successful planning of and operating in future peacekeeping operations.

The future will be complicated! At one time, when the members of peacekeeping operations numbered approximately 80,000, the United Nations thought that nothing more could be done, and a larger number of members was unthinkable. Today the number of members is significantly larger, development will most likely still continue and conditions will become even more demanding. I do not wish to forecast events which have not yet taken place. However, I would like to strongly emphasise that the history of peacekeeping operations is not over yet and that the future will be full of risks and challenges.

I would also again like to stress the importance of this issue of the Bulletin of the Slovenian Armed Forces, which is entering a new decade, and express my pleasure at being able to note down a few thoughts. Let me particularly emphasise that as Commander-in-Chief of the Slovenian Defence Forces I will continue to devote special attention to achievements in the area of cooperation in peacekeeping operations in the future, having a special interest in these experiences. I thank the authors of the articles of this important issue of the Bulletin for their scientific and professional contributions - and I greatly respect those who have already done important work in the name of the Republic of Slovenia with the Slovenian flag on their shoulders, with the hope that they continue to fulfil their obligations in accordance with the rules. 


\title{
PROJEKTIRANJE PREOBLIKOVANJA STRUKTURE SIL VOJSKE
}

\author{
PROJECTING THE TRANSFORMATION \\ OF MILITARY FORCE STRUCTURE
}

Povzetek Prispevek obravnava aktualna vprašanja projektiranja strukture sil, kar v tujini pojmujejo kot force planning oziroma programmed forces. Njegov namen pa je poleg predstavitve metodologije in procesa projektiranja strukture sil opozarjanje, da je nujen sprejem primerljive metodologije pri pristopu $\mathrm{k}$ oblikovanju razvojnih programov in preoblikovanju strukture sil Slovenske vojske. Tematika je v Slovenski vojski skoraj v celoti neraziskana, zato se zgledovanje in primerjanje z organizacijsko in menedžersko teorijo ter dostopnimi tujimi viri pojavljata kot nuja. Metodologija projektiranja strukture sil vojske v Republiki Sloveniji še ni v celoti izoblikovana in uveljavljena v praksi. Dostopni so nekateri modeli in tehnike, ki jih uporabljajo v industrijsko najrazvitejših državah v podporo projektiranju, ter za to usposobljen del kadra.

Ključne Reorganizacija in preoblikovanje, projektiranje organiziranosti, defense planning, besede force planning, projektiranje preoblikovanja strukture sil, preoblikovanje Slovenske vojske.

Abstract The article deals with the current questions of force structure projecting, which is abroad defined in terms of force planning or programmed forces. In addition to the presentation of methodology and the process of projecting force structure, the article's aim is to point out to the need for the adoption of a comparable methodology when approaching to the formation of development programmes and the reformation of Slovenian Armed Forces (SAF) structure re-formation. In the SAF, this topic is almost completely unexplored. Modelling upon and comparison with the organizational and manager theory and available foreign resources thus appears necessary. The methodology of force structure projecting in the Republic of Slovenia has not been completely formed and put into practice. There are some models and techniques available, used in industrially more developed countries in support of the projecting, as well as a group of adequately trained personnel. 
Key words Reorganization and re-formation, organizational projecting, defense planning, force planning, the process of projecting force structure reorganization, reorganization of Slovenian Armed Forces.

Uvod Preoblikovanje strukture sil vojske je odsev ogroženosti in drugih vplivov okolja, tehnično tehnološkega razvoja, funkcijskih potreb in življenjskega cikla določene vojaške strukture (enote, rodu, zvrsti). Ni vojaške organiziranosti, ki bi bila primerna za ves čas. Zato jo je treba nenehno prilagajati spremembam okolja in ogroženosti, spremembam v tehnologiji delovanja, vrstam in značilnostim bojnih sistemov ter fazam razvojnega cikla vojske. Navedeno pomeni, da je projektiranje organiziranosti strukture sil stalen, ponavljajoč se proces.

S sedanjim preoblikovanjem je tudi Slovenska vojska na razvojni prelomnici in pred pomembnimi izzivi. Te predstavljajo zlasti dejavnosti, povezane z njeno reorganizacijo in projektiranjem njene prihodnje strukture, ter dejavnosti in prizadevanja Republike Slovenije za vključitev v Nato. Pri tem je v ospredju vprašanje, kako oblikovati pravo strukturo in se izogniti nekritičnemu zgledovanju in kopiranju rešitev od drugod oziroma kako projektirati za prihodnost v razmerah, ko se okolje izredno hitro spreminja in je vedno težje predvidljivo.

\section{REORGANIZACIJA IN (ALI) PREOBLIKOVANJE}

Reorganizacija (preosnova, preureditev, preustroj) je spreminjanje organizacije in vzpostavljanje novih razmerij in struktur (Lipovec, 1987, str. 35). Nekateri avtorji načrtno spreminjanje organizacije definirajo kot organizacijski razvoj, za katerega sta značilna spreminjanje in inoviranje organizacije (Rozman, 1993, str. 190). Pri tem s spreminjanjem organizacije razumejo uveljavljanje novih zamisli, ki že obstajajo, z inoviranjem organizacije pa razumejo uveljavljanje novih, povsem na novo razvitih zamisli. Nekateri avtorji namesto inoviranja uporabljajo termin reinženiring. Reinženiring pojmujejo kot novo organizacijsko revolucijo, ki temelji na tem, da je treba staro organizacijo in njena načela preprosto zbrisati, odpraviti in začeti znova (Vila, 1997). Terminološka dilema glede reorganizacije in (ali) preoblikovanja obstaja tudi na obrambnem področju v svetu in pri nas ${ }^{1}$. Najpogosteje se z izrazom reorganization razume tako reorganizacija (spreminjanje) kot preoblikovanje (inoviranje) strukture sil, to pomeni, da se izraza uporabljata kot sinonima. Poleg tega izraz preoblikovanje na vojaškem področju najpogosteje prevajamo v reorganization.

Organizacijsko spreminjanje Slovenske vojske bo v prihodnosti povzročilo spreminjanje sedanjih organizacijskih in strukturnih elementov, pa tudi uvajanje povsem novih. Če se bomo tako kot v večini evropskih držav odločili za konceptualne spremembe (sprememba tipa vojaške organiziranosti zaradi drugačnega popolnjevanja vojske), bo treba zlasti preoblikovati (inovirati) strukturo sil.

1 Pri nas se v strateških in razvojnih dokumentih najpogosteje uporablja izraz preoblikovanje Slovenske vojske. 


\section{DEFENSE PLANNING IN FORCE PLANNING: NAČRTOVANJE OBRAMBNEGA SISTEMA IN NAČRTOVANJE SIL}

Defense planning in force planning sta pojma, ki se v angleški verziji uporabljata za opredelitev obrambnega načrtovanja in projektiranja organiziranosti obrambnega sistema ter načrtovanja sil in projektiranja organiziranosti vojaških sil. Prevod oziroma slovenska izraza bi bila načrtovanje obrambnega sistema in načrtovanje sil.

Treba je ločiti načrtovanje in projektiranje organiziranosti obrambnega sistema (obrambe) od načrtovanja in projektiranja organiziranosti vojaške organizacije (vojske). V industrijsko najrazvitejših državah je ta razmejitev prepoznavna, čeprav ostre ločnice v praksi med njima ni in se prepletata. Za projektiranje obrambnega sistema in obrambno načrtovanja se uporablja izraz defense planning ${ }^{2}$. Za projektiranje vojaške organiziranosti in načrtovanje sil pa se najpogosteje uporablja izraz force planning, redkeje programmed forces (Dictionary of military terms, 1995, str. 278). Pri force planningu je poudarek na določanju ciljev, doktrine, taktike in operatike, pri programmed forces pa na »programiranju« strukture sil. Isti vir uporablja za vojaško načrtovanje (delovanja) izraz military planning.

Defense planning pokriva potrebe institucionalno-političnega načrtovanja in obsega načrtovanje obrambne politike in strategije ter načrtovanje in programiranje (letno in večletno oziroma srednje- in dolgoročno) financiranja obrambe in upravljanja virov na eni strani ter projektiranje organiziranosti obrambnega sistema na drugi strani.

Dejavniki, ki določajo naravo defense planninga, so: nacionalni cilji, razpoložljivi viri, upravne in organizacijske značilnosti države, dojemanje grožnje in nasprotnika ter tehnologija s svojimi omejitvami. Pristopi in metodologija defense planninga so med državami različni ${ }^{3}$, čeprav obstaja veliko mehanizmov, zlasti znotraj držav članic Nata, in prizadevanj, npr. med članicami Partnerstva za mir, za doseganje njegove primerljivosti in transparentnosti. Izdelki defense planninga so praviloma akti, ki jih sprejema parlament ali vlada (zakoni, programi, smernice, proračuni ipd.), in so letni ali večletni oziroma dolgoročni. Izdelke pripravljajo posebne organizacijske enote znotraj obrambnega ministrstva ali (in) parlamenta.

Force planning obsega postopke načrtovanja in projektiranja sil kot odgovor na grožnjo in tveganja z doktrino, operatiko in taktiko, s strukturo sil ter z bojno sposobnostjo in zmogljivostjo sil. Naslanja se na defense planning, ki zagotavlja strategijo, oceno grožnje in scenarije s sprejemljivim tveganjem ter seveda razpoložljive finančne vire. Ima osrednjo vlogo v zagotovitvi razvoja sil in sposobnosti vojaških sil, potrebnih za njene različne naloge, ter predstavlja fokus za povezovanje delovanja in drugega načrtovanja (Boland, 1998, str. 32). Force planning izvajajo posebne organizacijske enote navadno v generalštabih. Redkeje

International Military and Defense Encyclopedia, 1993, str. 2144.

V ZDA uporabljajo tako imenovani PPBS (Planning, Programming and Budgeting System), ki ga je vpeljal

Robert McNamara že leta 1960. 
je združen z organizacijsko enoto, odgovorno za defense planning, s katero pa tesno sodelujeta. V načrtovalnem smislu je širši od projektiranja preoblikovanja strukture sil vojske, čeprav je to njegov najpomembnejši del.

Načrtovanje sil predstavlja celoto dejavnosti in postopkov, s katerimi se zagotavljata usklajenost in stabilnost njenega razvoja. Z načrtovanjem sil se dolgoročno in srednjeročno usmerjajo razvoj in spremembe obsega in organizacijske strukture, kadrovski sistem, opremljanje in modernizacija ter alokacija obrambnih virov.

\section{PROJEKTIRANJE ORGANIZIRANOSTI}

Zasnovanje in preosnovanje organiziranosti seuporabljajorazličniizrazi:projektiranje organiziranosti, modeliranje organiziranosti, organizacijska zgraditev, oblikovanje organiziranosti, organiziranje, strukturiranje itn. V slovenski organizacijski teoriji se najbolj uveljavlja izraz projektiranje modelov organiziranosti in to preučuje posebna znanstvena disciplina organizational design - projektiranje organizacije (Ivanko, 1999, str. 83). Naloga te organizacijske discipline je, da poskuša odgovoriti na vprašanja, kako mora biti organizirana organizacija, da bo uspešno delovala v danih razmerah. Preučitev in primerjava kažeta, da se je tudi pri projektiranju preoblikovanja strukture sil v vojski mogoče zgledovati po omenjeni znanstveni disciplini. Vse dileme pa s tem gotovo niso odpravljene. Pomembno vprašanje namreč je, ali gre pri projektiranju organiziranosti za plansko funkcijo ali funkcijo organiziranja. ${ }^{4}$ Organizacijska in menedžerska teorija pripisujeta vzpostavljanje razmerij in struktur funkciji organiziranja, z načrtovanjem pa razumeta predvsem zamišljanje celotnega poslovanja (delovanja) organizacije skupaj $\mathrm{z}$ določanjem planskih ciljev in delovanja.

Projektiranje preoblikovanja strukture sil v vojski je snovanje spreminjanja strukture organiziranosti vojske in njenega sistema vodenja $\mathrm{z}$ uporabo ustrezne metodologije in podpore. S projektiranjem preoblikovanja strukture sil v vojski razumemo najprej postopke načrtovanja sprememb strukture in zatem postopke organiziranja oziroma njihovo vzpostavljanje.

\section{VPLIVNI DEJAVNIKI ZA PROJEKTIRANJE PREOBLIKOVANJA STRUKTURE SIL}

V sedanjih razmerah je pri projektiranju preoblikovanja strukture sil treba upoštevati novo organizacijsko paradigmo vojske, ki je vedno bolj destrukcija stare in izraz vplivnih dejavnikov. Glavne značilnosti nove organizacijske paradigme vojske so:

\footnotetext{
Izraz projektiranje se največ uporablja v tehniki in izhaja iz latinskega izraza proiectum (projekt); ima ožji in širši pomen. V ožjem pomenu pod pojmom projektiranje razumemo načrt, skico, predlog za delo, postopek, $v$ širšem smislu pa pomeni vsako delotvorno zamisel, odločitev. Projektirati pomeni napraviti načrt, projekt. Projektiranje je torej reševanje sestavljenih problemov oziroma ustvarjalni proces, v katerem se na temelju osnovnih prvin in znanja oblikuje neki sistem. Ker je sistem organizirana celota, ni vsebinske razlike med organiziranjem in projektiranjem (Ivanko, 1999, str. 83).
} 
1. uporaba oboroženih sil je $\mathrm{v}$ sodobnih razmerah kompleksna in jo je mogoče razumeti le z upoštevanjem te kompleksnosti,

2. uvajanje sprememb v strukturi kadrovske sestave in profesionalizacija,

3. pripravljenost za hitro strukturno prilagajanje in raznolikost organizacijskih oblik,

4. večspektralnost oziroma uporaba sil v širokem spektru ogrožanj varnosti in

5. uveljavljanje večstranskega in večnacionalnega sestavljanja in uporabe sil.

Iz prej navedenega izhajata dve temeljni zahtevi za projektiranje preoblikovanja, to sta stabilnost in fleksibilnost organizacije. Stabilnost vojaške organizacije se izraža v ohranjanju bojne sposobnosti in zmogljivosti sil za izvajanje institucionalno določenih nalog, fleksibilnost pa $\mathrm{v}$ nenehnem strukturnem prilagajanju glede na vplivne dejavnike. Stabilnost organizacije in njena fleksibilnost sta v navideznem nasprotju, čeprav imata isti cilj v učinkovitosti organizacije. Zato je pri projektiranju organiziranosti treba iskati temu primerne organizacijske modele in rešitve.

Kot zelo pomembni je treba pri strukturiranju vojaških organizacij upoštevati tudi centralizacijo in decentralizacijo. Vprašanje centralizacije in decentralizacije v vojaški organizaciji ima več vidikov. Pri tem je v ospredju razmerje med njima oziroma razmejitev izvajanja posameznih postopkov in uresničevanja funkcij. Centralizacija odločanja v vojaški organizaciji ni dvomljiva, pomembna pa je z vidika disperzije pristojnosti po ravneh. Zelo pomembno je, da pri projektiranju strukture sil dosežemo organizacijsko ravnotežje med centralizacijo in decentralizacijo.

Izid organiziranja je organizacijska struktura. Pri oblikovanju organizacijske strukture je treba upoštevati zlasti štiri temeljne prvine. Te so: specializacija, standardizacija, koordinacija in avtoriteta. ${ }^{5}$

$\mathrm{V}$ vojaški organizaciji so pomembni trije vidiki avtoritete, in sicer enotnost ukazovanja, hierarhija in kontrolni razpon. Pri avtoriteti je treba razlikovati linijsko in štabno (funkcijsko) avtoriteto. Enotnost ukazovanja pomeni, da mora vsak element imeti enega vodjo. Hierarhija predstavlja čisto in nepretrgano verigo nadrejenosti in podrejenosti ter ukazovanja, ki povezuje posamezne elemente v organizaciji. Glede na število hierarhičnih ravni je organizacijska struktura lahko visoka ali nizka.

Velja prepričanje, da je kontrolni razpon glavni vidik organizacijske strukture. Mnogi teoretiki organizacije so se ukvarjali s preučevanjem optimalnega kontrolnega razpona in pri tem spoznali, da je za višje organizacijske ravni primernejši ožji razpon, za nižje organizacijske ravni pa širši razpon.

\footnotetext{
Specializacija je stopnja delitve skupne delovne naloge na posamezne delovne naloge. Specializacija je torej opredeljevanje posebnih nalog in njihovo dodeljevanje posameznikom ali skupinam. Standardizacija opredeljuje organizacijske postopke tako, da se delovne naloge opravljajo enotno in konsistentno. Koordinacija obsega formalne in neformalne postopke povezovanja dejavnosti, ki jih izvajajo posamezniki ali skupine $v$ organizaciji. Z vertikalno koordinacijo se določa število ravni, s horizontalno pa število organizacijskih podenot na določeni ravni. Avtoriteta je pravica delovati in odločati ter določa, kdo je komu odgovoren in kdo komu poroča (Možina et. al., 1994, str. 382).
} 
Vplivni dejavniki za organiziranje struktur so vsi tisti, ki neposredno ali posredno vplivajo na strukturiranje in oblikovanje organiziranosti. Organizacijska teorija razlikuje dve temeljni skupini vplivnih dejavnikov ${ }^{6}$ :

1. zunanje dejavnike in

2. notranje dejavnike.

Primerjava kaže, da je takšna delitev sprejemljiva tudi pri razvrščanju vplivnih dejavnikov za projektiranje organiziranosti strukture sil v vojski. ${ }^{7}$

Zunanji vplivni dejavniki so tisti, ki se pojavljajo v interakcijah vojaške organizacije z okoljem, v katerem deluje. Najpomembnejši so:

1. viri ogrožanja, obrambna politika in naloge vojske,

2. institucionalna organiziranost,

3. družbene vrednote,

4. financiranje obrambnih potreb,

5. zgodovinske okoliščine in tradicija,

6. razvoj znanosti in tehnike.

Pojavlja se vprašanje o obravnavanju ogroženosti kot izhodiščnega vplivnega dejavnika ter kako obravnavati ogroženost - kot samostojni dejavnik ali v povezavi s politiko in na tej podlagi določenimi nalogami vojske. Ogroženost je izhodiščni dejavnik in je ne glede na spremembe v okolju in njeno spreminjanje še vedno pretežno institucionalna. Je podlaga za snovanje politike, namembnosti in nalog vojske, to pa je izraženo v strateških in doktrinarnih dokumentih, s čimer kaže svoj institucionalni značaj. Ogroženost ima tudi svoje dejanske pojavne oblike, ki se spreminjajo. Problemi nastanejo takrat, ko je razlika med dejansko in institucionalno predvideno ogroženostjo prevelika in zato prihaja do organizacijskih in strukturnih neskladij v obrambnem sistemu in vojski. Zaradi tega so v vojski razviti mehanizmi za zagotavljanje stabilnosti organizacije ter ukrepi in postopki za preprečevanje presenečenja na eni strani in zagotavljanje že omenjene fleksibilnosti organizacijskih oblik na drugi strani.

Notranji vplivni dejavniki so posebnosti vojaške organizacije, ki izhajajo iz njenega notranjega okolja, njene strukture in razvitosti. Najpomembnejši so:

1. cilji in doktrina delovanja,

2. taktika in operatika uporabe sil,

\footnotetext{
Vplivni dejavniki za strukturiranje organiziranosti; Ivanko, 1999, str. 17-22, in Sikavica, 1991, str. 2.

Možen je tudi drugačen pristop. Po letu 1980 so ameriški raziskovalci organizacije razvili celostni model 7-S obravnavanja in spreminjanja organiziranosti sodobnih organizacij (Ivanko, 1999, str. 6). Sestavine modela so $v$ bistvu elementi kompleksne organiziranosti. Celostni model 7-S se imenuje zato, ker se vse njegove variable začenjajo s črko S. Te variable, v katere sta usmerjena obravnavanje in spreminjanje organiziranosti, so: (1) strategije /Strategy/, (2) strukture /Structure/, (3) sistemi /Systems/, (4) skupne vrednote /Shared values/, (5) sodelavci /Staff/, (6) slog ravnanja /Style/ in (7) sposobnosti, znanje in veščine /Skills/. Variabla (3) sistemi obsega: sistem načrtovanja (dolgoročnega, letnega in operativnega), informacijski sistem in sistem kontrole. Strategije, strukture in sistemi predstavljajo trde variable, nasprotno pa so tiste, na katere se znotraj organizacije laže vpliva, mehke variable, in sicer: skupne vrednote, sodelavci-osebje, slog delovanja ter sposobnosti, znanja in veščine. Celostni model 7-S ne negira notranjih in zunanjih dejavnikov, temelji pa na spoznanju, da organizacije dosegajo učinkovitost in uspešnost, če lahko spreminjajo organiziranost po vseh variablah sočasno.
} 
3. kadrovska struktura,

4. vodstvo,

5. motivacijska struktura,

6. vojaška tehnologija, ki je na razpolago,

7. vojaška infrastruktura,

8. velikost organizacije in

9. sposobnost preoblikovanja in prilagajanja.

\section{PROJEKTIRANJE PREOBLIKOVANJA STRUKTURE SIL VOJSKE}

Projektiranje preoblikovanja strukture sil je proces, sestavljen iz medsebojno povezanih postopkov, ki potekajo po določenih načelih in se izvajajo z metodami projektiranja. Navedel sem že, da s projektiranjem najprej razumemo postopke načrtovanja sprememb strukture in nato postopke organiziranja oziroma njihovega vzpostavljanja. V nadaljevanju bodo predstavljena tista določila organizacijske teorije, ki veljajo tudi za projektiranje preoblikovanja strukture sil v vojski.

Organizacijska teorija (Ivanko, 1999, str. 83) pozna dva pristopa k projektiranju modelov organiziranosti:

1. ad hoc pristop in

2. sistematično-načrtni pristop.

Za ad hoc pristop je značilno, da se organizacijski problemi rešujejo takrat, ko ti nastanejo. Takšni pristopi so največkrat zapozneli, ker gre za gašenje problemov. Nemalokrat takšen pristop povzroči še večje probleme, za obvladovanje katerih so potrebni še obsežnejši intervencijski ukrepi.

Sistematično-načrtni pristop k projektiranju organiziranosti je preventivni pristop $\mathrm{k}$ reševanju organizacijskih problemov. Projektiranja se lotevajo načrtno, da bi pravočasno odpravili disfunkcije, ki nastajajo. To pomeni, da se projektiranje preoblikovanja strukture sil pojavlja kot sistematičen in stalen proces. $\mathrm{V}$ vojaških organizacijah $\mathrm{v}$ vojnih razmerah večinoma uporabljajo ad hoc pristop pri spreminjanju organizacijske strukture sil. Zgodovina potrjuje, da je bilo zlasti neposredno pred vojnami in v vojnah veliko takšnih sprememb uspešnih. V mirnodobnih razmerah pa se lahko takšen pristop velikokrat spremeni v postopek improviziranja in eksperimentiranja. Zato za vojske kot kompleksne organizacije in sočasno velike finančne (proračunske) porabnike velja, da svojo strukturo spreminjajo in preoblikujejo tako, da dolgoročno načrtno uporabljajo za projektiranje organiziranosti sistematično-načrtni pristop. Dolgoročni načrtni pristop pomeni praviloma ciklično spreminjanje organiziranosti, povezano s tehnično-tehnološko modernizacijo sil in delovanja. ${ }^{8}$

\footnotetext{
Za ciklično spreminjanje strukture vojaških organizacij je značilno, da se cikli časovno krajšajo glede na dvigovanje stopnje tehnično-tehnološkega razvoja, to kaže na obratno sorazmernost. Do devetdesetih let je veljal desetletni cikel, po razpadu blokovske bipolarnosti pa se je prepolovil.
} 
Načela načrtnega pristopa k projektiranju preoblikovanja strukture sil so 9 :

1. obravnavanje projektiranja preoblikovanja strukture sil kot sestavnega dela načrtov organizacije in njenega razvoja;

2. uvajanje smotrnih organizacijskih rešitev, ki so povezane med seboj;

3. projektiranje preoblikovanja strukture sil z uporabo ustreznih metod in tehnik;

4. ustvarjanje potrebnih pogojev za uresničitev projekta spreminjanja strukture sil;

5. ustvarjanje organizacijske klime za izvajanje projekta in uresničitev sprememb.

Projektiranje preoblikovanja strukture sil v vojski zahteva sistematičen pristop, ki omogoča reševanje zapletenih organizacijskih problemov in temelji na izhodiščih, da se spoznajo trenutne razmere, da se rešitve usmerijo k problemom in njihovemu preseganju ter da koncipiranje rešitev poteka od grobega k detajlnim ob upoštevanju bojne sposobnosti ter zmogljivosti sil in stroškov.

Projektiranje preoblikovanja strukture sil v vojski opredelimo z naslednjimi fazami ${ }^{10}$ :

\section{Sprožanje projektiranja}

1. opredelitev strategije za preoblikovanje

2. opredelitev nalog, ki izhajajo iz strategije za preoblikovanje

3. opredelitev resursov (čas, kadri in sredstva) za preoblikovanje

4. ocena učinkov preoblikovanja

5. opredelitev organiziranosti za projektiranje preoblikovanja

\section{Ocenjevanje trenutne organiziranosti}

1. opredelitev metodologije raziskovanja obstoječe organiziranosti

2. preučitev obstoječe organiziranosti

3. analiza stanja in ugotovitev disfunkcij

4. oblikovanje (terapevtskih) ukrepov in priporočil ter dopolnitev strategije za preoblikovanje

\section{Oblikovanje modela organiziranosti}

1. postavitev načrta oblikovanja modela organiziranosti

2. oblikovanje modela organiziranosti - osnovni primer

3. preveritev predloga modela organiziranosti - osnovni primer

4. razvoj alternativ in njihova preveritev

5. izbor in dokončno oblikovanje modela organiziranosti

6. elaboriranje in potrditev projekta preoblikovanja

\section{Izvedba projekta preoblikovanja}

1. izdelava načrta izvedbe preoblikovanja

2. izdelava aktov za izvedbo preoblikovanja

3. priprava in poučevanje kadrov za izvedbo preoblikovanja

4. uvajanje organizacijskih sprememb

5. spremljanje in nadzor izvedbe

9 Povzeto in prirejeno po Ivanko, 1999, str 86.

${ }^{10}$ Povzeto in prilagojeno po Ivanko (od Buble), 1999, str. 102-103. 
Predstavitev faz postopka projektiranja preoblikovanja strukture sil nas opozarja na zahtevnost procesa. Ključna vprašanja projektiranja preoblikovanja so povezana z odločanjem v posameznih fazah oziroma ob njihovih zaključkih, s čimer se omogoča nadaljnji potek.

\section{PROJEKTIRANJE PREOBLIKOVANJA STRUKTURE SIL VOJSKE}

$\mathrm{S}$ postavitvijo strategije za izvedbo preoblikovanja ${ }^{11} \mathrm{v}$ prvi fazi se določijo cilji in naloge, ki izhajajo iz ciljev, ter oblikujejo zamisel in usmeritve za projektiranje ter izvedbo preoblikovanja. Toje naloga vodstva. Strategija za izvedbo preoblikovanja pa je tudi izhodišče za snovanje pristopa ter uporabo metod in orodja med projektiranjem. Strategija za izvedbo preoblikovanja predstavlja vhod v projektiranje preoblikovanja strukture sil. Pri oblikovanju strategije za preoblikovanje konceptualne, normativne in strateško-doktrinarne opredelitve in druga izhodišča usmerimo v cilje, zamisel in usmeritve za izvedbo ter naloge, ki jih je treba uresničiti pri projektiranju preoblikovanja strukture sil in pri preoblikovanju. Ob koncu prve faze je treba sprejeti odločitev o nadaljevanju projektiranja preoblikovanja ter dati usmeritev za preučitev in analizo obstoječe organiziranosti.

Ocenjevanje obstoječe organiziranosti je druga faza projektiranja preoblikovanja strukture sil. Njegov namen je analiza stanja, ugotovitev disfunkcij in oblikovanje ukrepov ter izhodišč za snovanje alternativ modelov organiziranosti v nadaljevanju procesa. Rezultati analize so podlaga za dopolnitev strategije za preoblikovanje. Sprejem ukrepov in izhodišč za preoblikovanje in dopolnitev strategije za preoblikovanje ob koncu druge faze ter odločitev o nadaljevanju projektiranja sprožita naslednjo fazo. Pri ocenjevanju obstoječe organiziranosti je treba ugotoviti, kakšne so alternative za njeno spreminjanje. To je pomembno zlasti takrat, kadar se odločamo za preoblikovanje oziroma reinženiring organizacije. Takrat v bistvu ugotavljamo in presojamo konceptualne možnosti. Ugotovitev alternativ je osnova za oblikovanje različic modelov organiziranosti.

V tretji fazi oblikujemo več modelov organiziranosti in najustreznejšega po potrditvi elaboriramo v projekt preoblikovanja strukture sil. Najprej se oblikuje osnovni primer (osnovna varianta) modela organiziranosti, nato se preskusi s podpornim orodjem, ki je na razpolago. Preskus pokaže prednosti in pomanjkljivosti glede na stroške in sposobnost ter zmogljivost sil, to pa je izhodišče za snovanje alternativ. S postavitvijo alternativ se postopek oblikovanja modela organiziranosti ponavlja tako, da se spreminjajo posamezni elementi na osnovnem primeru ali gradi popolnoma nov model. Oblikovanje več različic se med projektiranjem pojavlja kot temeljni pogoj za učinkovito odločanje o modelu organiziranosti. Potrditev izbrane različice omogoča dokončno oblikovanje modela organiziranosti in elaboriranje v projektu preoblikovanja.

\footnotetext{
"Menedžerska teorija uporablja izraz strategija (Rozman, 1993, str. 84). Pri nas bi takšno pojmovanje lahko bilo dvomljivo zaradi sprejete hierarhije dokumentov. V vsakem primeru gre za usmerjevalni dokument in sodi med akte vodenja vojske, zato bi ga imenovali Usmeritve za preoblikovanje ali Obvezne usmeritve za preoblikovanje.
} 
Ključne odločitve se sprejemajo v tej fazi; odvisno od metodologije in modelov za podporo odločanja so lahko sprotne ali ob posameznih presekih oziroma ob koncu oblikovanja projekta.

Izvedba preoblikovanja strukture sil poteka v četrti fazi in predstavlja aplikacijo projekta, obsega pa izdelavo načrta izvedbe, priprave za izvedbo, uveljavljanje sprememb ter spremljanje in nadzor uresničevanja projekta preoblikovanja.

V tej fazi je treba potrditi načrt izvedbe preoblikovanja in sprejeti odločitve o izvedbi preoblikovanja. Pozneje moramo glede na ugotovitve spremljanja in nadzora poteka zagotoviti sprejemanje korektivnih odločitev.

Projektiranje uvajanja sprememb lahko poteka ${ }^{12}$ :

1. z vrha navzdol,

2. od spodaj navzgor,

3. z obeh strani (bipolarno),

4. po smereh (klinih),

5. po jedrih (področjih).

Odločitev za eno izmed možnosti je odvisna od aktualnega stanja, ciljev in strategije za preoblikovanje strukture sil ter razpoložljivega časa za uresničitev sprememb.

\section{METODE PRI PROJEKTIRANJU}

Kompleksnost projektiranja zahteva izbiro in uporabo ustreznih metod. Z metodami izvajamo posamezne postopke pri projektiranju preoblikovanja strukture sil (ocenjujemo, analiziramo, načrtujemo in programiramo, simuliramo in preskušamo ipd.). Ravno kombinacija metod omogoča oblikovanje najučinkovitejše strukture.

Pri projektiranju strukture sil se najpogosteje uporabljajo kompleksna analitična in kompleksna matrična metoda projektiranja, klasična metoda projektiranja in sodobni računalniški programski paketi ali modeli, ki temeljijo na metodah operacijskih raziskav.

Pri projektiranju strukture sil v vojski je zaradi posnemanja oziroma prenosa določenih obstoječih organizacijskih oblik in struktur še vedno močno prisotna klasična metoda projektiranja. Ta temelji na prilagajanju obstoječih ali uveljavljenih modelov organiziranosti. Izbrani model organiziranosti adaptiramo in prilagodimo konkretni organizaciji, zatem pa analiziramo odmike stvarnega stanja organiziranosti glede na adaptirani vzorčni model.

\footnotetext{
12 Povzeto po Ivanko, 1999, str. 87: Strategiji pristopanja k projektiranju modelov organiziranosti.
} 
Kompleksna analitična metoda je namenjena predvsem analitičnemu ocenjevanju funkcij in organiziranosti, lahko pa se uspešno uporabi tudi za preoblikovanje in projektiranje novih modelov organiziranosti.

Kompleksna matrična metoda temelji na nalogi kot izhodišču za projektiranje modela organiziranosti. Delovanje organizacije se členi do takšne stopnje, da omogoča projektiranje makro-, mezo- in mikromodela organiziranosti in uporabo matrike za odločanje. Analiza in členitev nalog ter delovanja je nujno poprejšnje opravilo za uspešno celovito projektiranje. Uporaba kompleksne matrične metode je primerna za projektiranje strukture vojaških sil zlasti pri oblikovanju makro- in mikromodela organiziranosti.

Metode operacijskih raziskav se pri projektiranju organiziranosti uporabljajo množično. Sodobnega projektiranja strukture sil brez uporabe metod in modelov operacijskih raziskav tako rekoč ni mogoče uspešno izvesti. Pri tem je treba poudariti metode vojnih iger, zlasti vojne igre za potrebe načrtovanja, nadalje metode simulacij kot ene od najmočnejših analitičnih orodij na področju operacijskih raziskav in posebne modele za simulacijo obrambnih izdatkov in za simulacijo učinkovitosti strukture sil.

Razvoj operacijskega raziskovanja, zlasti modeliranja in metod simulacij, je omogočil razvoj metod za kvantitativno merjenje modernizacije vojaških sil in njihove učinkovitosti. Do danes so bile razvite številne metode, ki za vrednotenje uporabljajo ocenjevalne modele oborožitvenih sistemov in veliko spremljevalnih modelov za ocenjevanje drugih kvalitativnih vidikov vojaških sil, kot so osebje, poveljevanje in kontrola, logistika ipd.

Modeli zagotavljajo statične indikatorje sposobnosti in zmogljivosti vojaških sil, temelječih na značilnostih in količini posameznega orožja in izraženih kot numerični rezultat (točke bojne sposobnosti in zmogljivosti). Individualno vrednotenje posameznih oborožitvenih sistemov (letala, rakete, topovi, tanki in druga oklepna bojna vozila, mornariška bojna sredstva idr.) se izvaja po njihovih tehničnih zmogljivostih (vrsta, hitrost, nosilnost, domet, manevrske sposobnosti ipd.), pa tudi po sposobnosti zadevanja in uničenja ciljev ter zmožnosti uporabe in vodenja sistema. Relativna pomembnost teh značilnosti posameznih oborožitvenih sistemov se računa s težnostnimi dejavniki - ponderji, uporabljajoč metodo Delphi in metodo AHP (Analytic Hierarchy Process). Posamezne vrednosti oborožitvenih sistemov lahko uporabimo posamično ali jih kombiniramo za izdelavo zbirnih teoretičnih zmožnosti sil. Za nekatere analitične primere pa teoretične sposobnosti in zmogljivosti oborožitvenih sistemov ali teoretične sposobnosti in zmogljivosti sil niso zadostne. Zato ocenjevanje realne sposobnosti in zmogljivosti sil zahteva tudi vrednotenje neotipljivih (neoborožitvenih) vidikov vojaških sil, kot so poveljevanje in kontrola ter delovanje sistemov C4I, logistična organizacija in podpora ter vzdržljivost sil, zmožnost mobilizacije in razvoja sil ter struktura sil in alokacija virov. Za te potrebe so razviti posebni modeli, ki omogočajo bolj realno ovrednotenje bojne sposobnosti in zmogljivosti. 


\section{DRMM - MODEL ZA PODPORO PROJEKTIRANJA PREOBLIKOVANJA STRUKTURE SIL}

Defense Resource Management Model, skrajšano DRMM, v prevodu model upravljanja obrambnih virov, je računalniški model, ki so ga razvili za potrebe podpore načrtovanja na obrambnem ministrstvu $Z^{2} A^{13}$. To analitično orodje je namenjeno podpori načrtovanja obrambnih virov in projektiranju vojaške strukture sil, torej pri defense planningu in force planningu.

Predstavitev modela za podporo projektiranja je pomembna zato, ker opozarja na metodološke posebnosti pri projektiranju preoblikovanja strukture sil vojske in kaže, kako je treba spremeniti dosedanjo prakso pri snovanju organiziranosti tako, da bo izhajala iz stroškov in razpoložljivih virov ter bo glede na navedeno uresničljiva.

Model je orodje za analiziranje (študijo) na makro ravni in za podporo odločanju glede na stroške in sposobnost sil ter omogoča preveritev alternativ strukture sil skozi njihovo večletno načrtovalno obdobje. Bistvo DRMM je, da je za predlagani model organiziranosti mogoče ovrednotiti integrirano bojno sposobnost in zmogljivost sil glede na stroške, in to glede na nasprotnika (grožnjo) ali na alternativni model organiziranosti - alternativno strukturo. Model omogoča alokacijo stroškov in ocenjevanje bojne zmogljivosti in sposobnosti sil.

Z DRMM vrednotimo integrirano sposobnost sil na podlagi sistema točkovanja. Stroškovna analiza omogoča ocenitev stroškovnih prednosti nakupov različnih MTS $\mathrm{v}$ različnih programih razvoja sil. Z modelom lahko ovrednotimo tudi trenutno stanje sil, torej ga lahko uporabimo tudi za podporo ocenjevanja in analiziranja obstoječe organiziranosti.

Model omogoča kreiranje in modificiranje glavnih značilnosti strukture sil, operativne uporabnosti oborožitve in opreme, usposabljanja, vojnih rezerv, upravljanja in financiranja, s tem pa podpira dokončno oblikovanje (elaboriranje) projekta preoblikovanja ob koncu tretje faze projektiranja. Ko postavimo večletno projekcijo strukture sil in stroškov, model zagotavlja uporabniku velik spekter tabel in diagramov, ki predstavljajo različne vidike strukture sil oziroma njihovih specifičnih elementov, posameznih enot, tipov opreme, kategorij proračuna, stroškovnih mest ipd., to pa je kot podlaga uporabno pri izdelavi načrta za izvedbo preoblikovanja $\mathrm{v}$ četrti fazi projektiranja.

Program DRMM deluje na računalnikih, ki so skladni z IBM v okolju Windows. Komponenti DRMM sta modul sil in modul stroškov.

\footnotetext{
${ }^{13}$ To je orodje za podporo PPBS (Planning, Programming and Budgeting System) - sistema za načrtovanje, programiranje in proračunsko financiranje na obrambnem ministrstvu $Z D A$.
} 
DRMM modul sil obsega podatke, ki jih lahko razdelimo na te glavne skupine:

1. enote $v$ naši strukturi po ravneh,

2. oprema, s katero razpolagamo po vrstah in količini, glede na mirnodobno delovanje in kategorije, katerim pripada ta oprema,

3. osebje v strukturi sil po tipih osebja in plačilnih kategorijah,

4. viri, ki obsegajo človeške in materialne vire $v$ tako imenovanih vojnih rezervah.

Če želimo primerjati strukturo sil glede na strukturo sil nasprotnika, glede na grožnjo, s katero se spoprijema država, je treba vnesti v modul tudi sestavo nasprotnikovih sil.

DRMM uporablja metodologijo vrednotenja bojne sposobnosti in zmogljivosti opreme tako, da določi vsakemu tipu opreme v popisu določeno število (bojnih) točk. ${ }^{14}$ Sposobnost določene strukture sil je dobljena s seštevanjem (združevanjem) vseh točk za opremo v popisu. Ta seštevek točk pomeni statično vrednost sposobnosti določene strukture sil. Opremo, ki predstavlja nebojni del (npr. tovorna vozila, pontonski mostovi, ipd.), je treba prav tako vnesti v popis, saj predstavlja stroške, čeprav nima točk za bojno sposobnost in zmogljivost. To velja tudi za infrastrukturne objekte, čeprav le redki od njih dobijo točke za bojno sposobnost in zmogljivost, predstavljajo pa velik delež stroškov, ki so povezani z njimi. Model lahko prikaže zmanjšano sposobnost opreme glede na pomanjkanje virov ali glede na starost opreme.

Obstajajo štiri kategorije točk bojne sposobnosti in zmogljivosti opreme, in sicer glede na formacijo, dejansko stanje popolnitve, sposobnost za delovanje in učinkovitost. Model prikazuje skupno število točk po kategorijah.

DRMM stroškovni modul vključuje vse mirnodobne stroške (stroške delovanja):

1. stroške strukture sil,

2. stroške bojne pripravljenosti,

3. stroške investicij in

4. stroške vzdrževanja stanja.

V stroškovnem modulu oblikujemo stroške na enoto tako, da jih gradimo od spodaj navzgor, pri alokaciji virov pa tako, da stroške zajemamo od zgoraj navzdol. Pristop od spodaj navzgor zagotavlja, da so potrebe posameznih enot upoštevane v modeliranju ter prikazane možnosti proračunskega pokritja. DRMM omogoča upoštevanje inflacije, tako da lahko stroške prikažemo tudi s tega vidika. Ko vnesemo v baze podatkov DRMM vse podatke o obstoječem stanju sil ter predlagano strukturo sil v prihodnosti, nam model omogoča stroškovno preračunavanje. To zagotavlja uporabniku možnost ocenjevanja in primerjavo stroškov obstoječe strukture sil z alternativnimi.

\footnotetext{
${ }^{14}$ Za točkovno podlago uporablja orodje Technique for Assessing Comparative Modernization (TASCFORM) ali Equipment Potential capability Comparison (EPOCC).
} 
Podatkovne baze DRMM sestavljajo štiri baze:

1. baza podatkov o zgradbi sil,

2. baza podatkov o zgradbi stroškov,

3. baza podatkov o silah - enotah in

4. baza podatkov o stroškovnih dejavnikih.

Analiza (študija) DRMM je zasnovana kot stopenjski in delni-po delih ponavljajoči se postopek. Analiza obsega oblikovanje in razvoj baz podatkov, organiziranje aparata za izvedbo analize ter organiziranje in izvedbo postopka analize. Navedel sem že, da analiza podpira postopke tretje faze projektiranja preoblikovanja strukture sil.

Aparat za izvedbo analize obsega skupino za izvedbo, računalniško opremo in programsko orodje modela ter podporo z vidika zagotovitve baz podatkov. Skupina za izvedbo analize je sestavljena iz vodstva in potrebnega števila analitikov ter je funkcionalno organizirana. Po navadi se določi še skupina za vodenje analize (top menedžment) in ta opredeli izhodišča in zahteve za snovanje alternativ ter sprejema odločitve. Temeljni pogoj za izvedbo analize so potrjeni razvojni dokumenti oziroma načrti in strategija za preoblikovanje oziroma zamisel za izvedbo preoblikovanja strukture sil.

Potek analize obsega:

1. vzpostavitev osnovnega primera - modela organiziranosti,

2. vnos sil nasprotnika - opcije,

3. analizo osnovnega primera,

4. razvoj in analizo alternativ,

5. oblikovanje izdelkov analize,

6. predstavitev izdelkov analize in dopolnitev analize,

7. končno poročilo.

1. Vzpostavitev osnovnega primera je začetni del analize; podskupini za stroške in sile razvijeta osnovni primer oziroma model organiziranosti. Po vnosu podatkov za osnovno leto, in sicer za enote, osebje, opremo, vire in stroške, to leto premočrtno prekopiramo v druga leta in vnesemo vse spremembe v strukturi sil, osebju, modernizaciji, opremi in virih. Ta del torej obsega pridobivanje in vnašanje podatkov, ki so karakteristični elementi trenutnega in večletnega nacionalnega načrta razvoja strukture sil. Osnovni primer je večletni posnetek uradno odobrenega stanja strukture sil in razvoja strukture sil v prihodnje. Postavitev osnovnega primera je temeljni pogoj za razvoj alternativ in analize strukture sil glede na sposobnost in stroške.

2. Vnos sil nasprotnika (opcije) obsega oblikovanje podatkov o strukturi sil nasprotnika in vnašanje podatkov v model. Namen podatkov o silah nasprotnika je, da zagotovimo primerjavo sil kot realno ocenitev vojaške sposobnosti. Namesto podatkov o nasprotniku pa lahko uporabimo izmišljene podatke (opcije) oziroma podatke o silah, s katerimi bi želeli primerjati naš osnovni primer - model organiziranja. 
3. Analiza osnovnega primera poteka z analitičnim orodjem v modelu. DRMM zagotavlja tabelarne in grafične izdelke, ki jih uporabljamo kot pomoč za ocenitev osnovne strukture sil glede na bojno sposobnost in zmogljivost ter glede na mirnodobne stroške. Osnovni primer je referenčna točka za analizo sil in stroškovno analizo ter opis sposobnosti sil in stroškov v prihodnjih fiskalnih obdobjih. Stroškovna analiza omogoča zasledovanje stroškov časovno skozi pojavljajoča se obdobja in določanje proračunskih učinkov glede na potrebe po usposabljanju in opremljanju sil. Model DRMM zagotavlja tudi vpogled v specifične stroške, ki se pojavljajo (npr. delež stroškov, namenjen posamezni zvrsti ali rodu oboroženih sili, delež po namembnosti sil in dejavnostih ali stroške po proračunskih postavkah). Analitično orodje znotraj stroškovnega modula DRMM lahko izvaja analize kot npr. določanje časovnega obdobja, ki je potrebno, da zamenjamo letalo ali tank glede na sedanje in na pričakovane izdatke za nabavo, pripravo kadra, infrastrukture idr. Analiza sil daje odgovore na vprašanja o bojni sposobnosti in zmogljivosti sil ter razpoložljivosti vojske. Z izdelki DRMM in izkušnjami pri opredeljevanju in analiziranju vojaških sil podpremo opredelitev ključnih elementov osebi, ki odloča.

4. Razvoj in analiza alternativ se osredotočita na identifikacijo problemskih področij, ki jih je treba detajlno preučiti pri postavitvi alternativ. Namen razvoja alternativ je doseganje izboljšav na določenih področjih glede na osnovni primer - model organiziranja. Tako izvajamo nov ponavljajoč se cikel za kreiranje modela organiziranosti. Vključevanje stroškov v osnovni primer in odnos med našimi silami in silami nasprotnika je treba podrobno preučiti ter oceniti dejansko sposobnost naših sil. Če ugotovimo primanjkljaj $\mathrm{v}$ sposobnosti sil, je treba $\mathrm{v}$ novih alternativah preučiti te slabosti in jih kompenzirati ali poudariti potrebo po odločitvi o povečanem tveganju. Alternative lahko vključujejo prestrukturiranje sil, modernizacijo opreme, stopnjo virov, preusmeritev osebja, prelokacijo finančnih virov med področji proračuna. Večinoma razvijamo več kot eno alternativo znotraj usmeritev ali razvojne strategije in dodeljenega proračuna. Naprej se postopek ponavlja, analiziramo nove alternative strukture sil. Glavna razlika med analizami alternativ modelov organiziranosti in analizo osnovnega primera - modela organiziranosti je, da lahko alternative primerjamo tako glede na nasprotnikove sile kot tudi na druge alternative in na osnovni primer. Večina izdelkov DRMM dovoljuje predstavitev osnovnega scenarija nasprotnikovih sil in alternativ $\mathrm{v}$ istem poročilu grafično in tabelarno.

5. Oblikovanje izdelkov zagotavlja output v izvedbi analize. Temeljni namen oblikovanja izdelkov je priprava in predstavitev kazalcev za podporo odločanja. Vsi izdelki se ob koncu oblikujejo v integrirani dokument.

6. Pri predstavitvi izdelkov analize predstavimo izdelke analize in priporočila za odločanje skupini za vodenje analize ali drugemu vodilnemu osebju. Predstavitev izdelkov je lahko delna, lahko že poteka ali je končna. Po delnih predstavitvah se po navadi opravijo dopolnitve na podlagi novih usmeritev in zahtev. Seveda se dopolnitev lahko opravi tudi po končni predstavitvi izdelkov analize. Končna predstavitev vsebuje priporočila za odločanje in ta se potrdijo ali zavrnejo. 
7. Analiza se konča z oblikovanjem poročila o izvedbi in delu skupine za izvedbo analize ter s predajo poročila in izdelkov organizacijski enoti za projektiranje oziroma naročniku.

Izdelki analize DRMM predstavljajo široko paleto izpisov glede strukture sil in podatkov o stroških po izbiri uporabnika. DRMM zagotavlja dve obliki izpisov, in sicer tabelarne in grafične. Oblike izpisov so postavljene tako, da pospešijo pregled napak pri opredelitvi strukture sil ter podpirajo analize in ocenjevanje strukture sil.

Izdelek o strukturi sil je lahko: tabelarno poročilo o enotah, tabelarno poročilo o opremi, poročilo OPTEMPO (operativni tempo), tabelarno poročilo o virih, tabelarno poročilo o osebju, graf o točkah sposobnosti, ki predstavlja najmočnejši del za podporo analizam in ocenjevanju strukture sil, in graf o naraščanju sposobnosti.

Izdelek stroškov je lahko: pregled stroškovnih dejavnikov, poročilo o stroškovni različnosti, poročilo o rezultatu stroškov, specialno poročilo o stroških za osebje, za opremo in za nakupe opreme, poročilo o stroškovnem poizvedovanju in grafični prikaz stroškov.

Veliko izdelkov ima možnost za prenos ali zapis v elektronski obliki v druge programske pakete in to omogoča analitikom nadaljnje analiziranje podatkov, prenos podatkov v druge programe ter uporabo podatkov za druge oblike poročil in grafov.

\section{Kakšna je uporabnost in katere so pomanjkljivosti DRMM?}

DRMM je s svojo metodologijo primerjanja stroškov in sposobnosti enot s katero koli strukturo sil učinkovito analitično orodje. DRMM z modulom stroškov in sil omogoča fleksibilno analiziranje stroškov in sposobnosti kot osrednjim vprašanjem defense in force planninga. Uspešno lahko podpre oblikovanje modelov organiziranosti in snovanje projekta preoblikovanja strukture sil pri projektiranju.

DRMM omogoča kreiranje alternativnih scenarijev, povezanih s strukturo sil, stopnjo usposobljenosti, tipom in stopnjo modernizacije ter z vojnimi rezervami, in s tem opredelitev njihovih učinkov na obrambni proračun. Če želimo prikazati trende, lahko te učinke analiziramo skozi večletno obdobje. DRMM je učinkovito orodje, če se obvladuje metodologija in razpolaga $z$ ustreznim aparatom in predvsem usposobljenim kadrom. Učinkovito je takrat, kadar je ustrezno integrirano $\mathrm{v}$ projektiranje preoblikovanja strukture sil in obrambnega načrtovanja, ni pa nadomestilo zanj. DRMM ni projektiranje, temveč je podpora projektiranja.

Ima pa DRMM tudi omejitve in pomanjkljivosti. Največ organizacijskih težav pomeni zagotovitev ustrezne primerjave strukture sil (nasprotnika), zlasti takrat, kadar je natančno predvidevanje grožnje težje izvedljivo. DRMM ne pove uporabniku, kako najbolje alocirati vire, in ne more zamenjati vojaške presoje ter nadomestiti odločanja pri izbiri najboljše alternative. 
Model primerja in vrednoti le določene vrste opreme (težke oborožitve). Modul sposobnosti sil v DRMM upošteva le dejavnike, ki vplivajo na sposobnost in zmogljivost sil. Sistem točkovanja za sposobnost opreme je narejen po merilu ocenjevanja sposobnosti sil v okolju srednje Evrope. Dopolnitev vrednotenja bojne sposobnosti in zmogljivosti je sicer možna, vendar je zahtevna. Točkovni sistem ne zagotavlja ustreznega vrednotenja lahkih sil. Model tako zahteva dodatno podporo vrednotenja bojne sposobnosti in zmogljivosti zlasti za pehotne enote.

Model ne more $\mathrm{v}$ celoti vrednotiti prispevka elementov, kot so poveljevanje in kontrola, zveze, informatika, elektronsko bojevanje, psihološko delovanje, prelociranje sil. Prav tako ne upošteva vpliva doktrine, morale in drugih dejavnikov pripravljenosti sil.

Model je narejen na statični osnovi. DRMM ni dinamični model bojevanja (warfare) in ni vojna igra (wargame). Za dosego celovitosti in učinkovitosti pri oblikovanju modelov organiziranosti je zato treba poseči še po dodatnih modelih za simulacije in vojno preigravanje.

\section{PREOBLIKOVANJE SLOVENSKE VOJSKE - SEDANJI IZZIV ZA PRIHODNOST}

Dosedanji razvoj in snovanje vojske za prihodnost sta tudi pri nas predmet številnih strokovnih, pa tudi političnih obravnav in to samo potrjuje pomembnost in aktualnost teh vprašanj.

Osrednja značilnost dosedanje prakse je bila, da se je velikokrat projektiralo in odločalo z neustrezno podporo ali brez ustrezne podpore, ki mora spremljati politične in strokovne odločitve in postopke oblikovanja razvojnih programov, ter da je bil pri projektiranju strukture sil najpogosteje uporabljen ad hoc pristop, usmerjen v delne ali kratkoročne rešitve.

Menim, da je bil temeljni problem pri dosedanjem projektiranju preoblikovanja strukture sil Slovenske vojske v nejasnih ciljih in viziji, v predimenzionirani zasnovi obsega, v neizoblikovani strategiji preoblikovanja in v prepogostem spreminjanju težišč. Zaradi tega je bil stroškovni del projektiranja močno omejen ali zapostavljen. $\mathrm{S}$ spreminjanjem težišč preoblikovanja in razvojnih prioritet pa se je projektiranje strukture sil vedno znova vračalo na začetek in bilo ujeto v začarani krog s skromno realizacijo projektov. Dosedanje preoblikovanje strukture sil je potekalo po jedrih, del teh projektov preoblikovanja pa ni bil končan. Sistem dolgoročnega načrtovanja financiranja in razvoja na obrambnem področju, ki je veljal v nekdanji skupni državi, je bil leta 1991 opuščen, novi pa dolgo ni bil postavljen.

Ministrstvo za obrambo je leta 1997 znotraj dvostranskega sodelovanja z obrambnim ministrstvom (MOD) ZDA dobilo pomoč za uveljavljanje defense planninga in force planninga. Poleg svetovanja glede organizacije defense in force planninga je 
bilo prevzeto orodje DRMM, usposobljen je bil tim za delo na njem in izvedena je bila analiza. Analiza s tem orodjem je bila ponovno izvedena tudi v drugi polovici leta 2001 in končana v prvem četrtletju 2002. Razpoložljiva programska podpora za defense in force planning je na Ministrstvu za obrambo in v Slovenski vojski dobra. Poleg modela DRMM, ameriške metodologije PPBS, programskega orodja za vrednotenje bojne sposobnosti in zmožnosti ameriškega podjetja TASC (The Analytic Science Corporation), ki je razvilo tehnike za primerjalno ocenjevanje modernizacije sil TASCFORM (Technique for Assesing Comparative Force Modernization) in EPOCC (Equipment Potential Capability Comparison), obstajajo še bojni simulacijski modeli HORUS ${ }^{15}$ in JANUS ${ }^{16}$, s katerimi razpolaga Oddelek za raziskave in simulacije v Centru vojaških šol, in drugi.

Zagotovo bi se $\mathrm{z}$ boljšo izrabo dosegljive podpore ${ }^{17}$ lahko izognili večini pomanjkljivosti pri dosedanjem projektiranju strukture sil. Usposobljenost ljudi za projektiranje preoblikovanja strukture sil je vsekakor problem.

Strukturne, organizacijske in funkcionalne spremembe $\mathrm{v}$ obrambni in vojaški organiziranosti Republike Slovenije so nujne tudi zaradi sprememb, ki nastajajo s približevanjem EU in Natu. Pri tem Slovenija ne more zagotoviti celovite in časovno neomejene samozadostnosti obrambnega sistema. To že dolgo ni več stalnica tudi $\mathrm{v}$ velikem številu ekonomsko in demografsko močnejših držav.

Potrebe po preoblikovanju strukture in spreminjanju koncepta organiziranosti so razvojne potrebe Slovenske vojske, ki izhajajo iz cilja, da bo učinkovitejša, sodobnejša in primerljiva ter mednarodno povezljiva. Projektiranje preoblikovanja Slovenske vojske intenzivno poteka.

Izhodišča za preoblikovanje strukture sil Slovenske vojske so bila:

1. sprejeti strateški in doktrinarni ter dolgoročni razvojni dokumenti,

2. identificirano obstoječe stanje organiziranosti in analizirani vplivni dejavniki,

3. potrebe po preoblikovanju strukture sil in spreminjanju koncepta mezoorganiziranosti z obstoječimi alternativami,

4. vizija za izvedbo preoblikovanja,

5. zahteve po optimalizaciji strukture in ekonomizaciji prihodnjega modela organiziranosti.

\footnotetext{
${ }^{15}$ HORUS (Heeresmodell f.r Operations Research zur Untersuchung von Strategiefaktoren) je bojni model nemške zvezne vojske in proizvod podjetja IABG iz Ottobruna v Nemčiji. Namenjen je simulaciji boja na ravni bataljon/ brigada/divizija (Savšek, 2000, str. 114).

${ }^{16}$ JANUS je interaktivna računalniška zemeljska dvostranska brigadna simulacija ameriške vojske in proizvod Lawrence Livermore National Laboratoryja iz ZDA (Savšek, 2000, str. 124).

${ }^{17}$ Kljub temu da sta HORUS in JANUS namenjena vojnim igram in bojnim simulacijam, ju lahko uporabimo za pregled vpliva sprememb določenih parametrov bojne sposobnosti in zmožnosti sil ter za preslikavo podatkovnih baz v druge modele bojevanja ali ocenjevanja bojnih zmožnosti. Pomembni pa so tudi taktični kazalci vojne igre. Tako je študijska vaja znotraj vojaške operacijske raziskave (od novembra 2001 do marca 2002), namenjena preveritvi projektirane strukture sil Slovenske vojske do leta 2004, pokazala konceptualne slabosti v ZO in inženirstvu ter opozorila na posebnosti bojiščnih sistemov in zmožnosti brigade Slovenske vojske.
} 
Temeljna izhodišča za projektiranje preoblikovanja strukture sil Slovenske vojske opredeljujeta Obrambna strategija (december 2001) in Splošni dolgoročni program razvoja in opremljanja Slovenske vojske (november 2001). V vlogi strategije preoblikovanja se pojavlja Koncept preoblikovanja Slovenske vojske 2004, ki ga je potrdil minister za obrambo (november 2001). Vizija za izvedbo preoblikovanja temelji na postopnosti izvajanja sprememb, usklajeno z uvajanjem sprememb $\mathrm{v}$ drugih delih obrambnega sistema. Pri projektiranju preoblikovanja strukture sil in načrtovanju razvoja Slovenske vojske izhajamo iz optimalizacije strukture in ekonomizacije, ki temelji na strokovnih podlagah, ob upoštevanju kadrovskih, infrastrukturnih in proračunskih zmožnosti ter dejstvu, da se v sodobnih razmerah uspešnost modernih vojaških organizacij ne meri zgolj po obsegu fizične sile, temveč po odzivnosti in zmožnosti sil.

Projektiranje preoblikovanja strukture sil je zasnovano na realno dosegljivih finančnih in kadrovskih zmožnostih, težišče pa je povečanje kakovosti in zmanjševanje fizičnega obsega sil. Upoštevali smo metodološka dognanja in zahteve sistematičnega pristopa, o katerih je govor tudi v tem sestavku. Žal je bil stroškovni del projektiranja (programiranja) velikokrat sekundarnega pomena.

Funkcionalna povezanost in odvisnost vojaške obrambe od preostalega dela obrambnega sistema zahtevata sočasno načrtovanje in usklajeno izvajanje sprememb vseh sestavin. Zaradi tega projektiranje preoblikovanja strukture sil Slovenske vojske ne sme biti edino področje sprememb in ne more biti nepovezan proces. Zato so usklajene spremembe in reforme v obrambnem sistemu neizogibne. Lahko jih sicer odlagamo, ne moremo pa se jim izogniti zaradi sedanjega stanja in značilnosti ter trendov v širšem okolju. To potrjujejo dogajanja v številnih državah, v katerih pripravljajo in izvajajo organizacijske spremembe ne samo v strukturah oboroženih sil, temveč oblikujejo nove koncepte ter iščejo rešitve kot odgovore za sodobne nevarnosti in izzive. Za organizacijske spremembe je značilna stalnost. Zato se tudi v primeru Slovenske vojske pojavlja dilema, kako pravilno dimenzionirati cikle preoblikovanja, da bi zagotovili stalnost sprememb in se izognili stalnim reorganizacijam brez pravih učinkov in $\mathrm{s}$ tem zmanjševanju pripravljenosti za spremembe.

Sklep Spreminjanje in dopolnjevanje vojaške organiziranosti spadata med osrednje razvojne izzive in dejavnosti na obrambnem področju v mnogih državah. Dejstvo je, da se z vprašanji projektiranja nove strukture in preoblikovanja organizacijskih modelov intenzivno ukvarjajo organizacijske enote za defense in force planning.

Pri iskanju odgovorov na vlogo vojske v spremenjenih političnih in varnostnih razmerah ter rešitev glede reorganizacije obrambnih sistemov in preoblikovanja oboroženih sil in sprejemanja odločitev glede njihovega drugačnega popolnjevanja ter spremenjenih operativnih zahtev pri uporabi vojaške sile imata izredno pomembno vlogo metodologija in podpora načrtovanja ter projektiranja. 
Prejšnja ugotovitev velja tudi za Slovensko vojsko, predvsem zaradi omejenosti njenih virov. V mednarodne vojaške integracije lahko Slovenska vojska prispeva vojaške sile in ljudi, ki bodo po obsegu primerni zmožnostim. Predimenzioniranje tega prispevka pri projektiranju strukture sil lahko negativno vpliva na funkcioniranje celotnega sistema.

Dileme, ali so izbrane prave rešitve, so bile in bodo stalnica pri projektiranju modelov organiziranosti. Ni se jim mogoče izogniti niti pri projektiranju preoblikovanja strukture sil Slovenske vojske. Sodobne metode in orodje za podporo projektiranja lahko te dileme občutno zmanjšajo.

\section{Literatura}

1. Allied joint doctrine, AJP 01(A), 1998: NATO; Military agency for standardisation (MAS) chapter 2-Principles.

2. Boland, Frank: Force planning in the new NATO, NATO review, No. 3, Autumn 1998, p. $32-35$.

3. Brassey's multilingual military dictionary, 1989: Brassey's (US), Washington, D.C.

4. Defense Resource Management Model (DRMM), Users' Manual, 2000: Department of defense USA, Washington.

5. Defence restructuring and conversion - Sociocultural aspects, edited by Ljubica Jelušič and John Selby, 1999: European Commission, Directorate-General Research, Brusseles, p. 52-63, 183-198, 183-198.

6. Dictionary of military terms, by Greenhill Books, 1995: Butler \& Tanner Ltd., London.

7. International Military and Defense Encyclopedia, 1993: Brassey's (US), Washington, D.C. Volume 5 P-S, p. 2030-2044, 2144-2153.

8. Ivanko, Štefan, 1999: Urejenost podjetja - strukture in procesi, Visoka šola za management, Tiskarna Stražar, Koper.

9. Ivanko, Štefan, 1991: Razvoj in spreminjanje organizacije, Visoka šola za podjetništvo, Portorož.

10. Lah, Ivan, 1995: Operacijsko raziskovanje za častnike in obramboslovce, Ministrstvo za obrambo, I. uprava, Tiskarna Formatisk, Ljubljana.

11. Lipovec, Franjo, 1987: Razvita teorija organizacije, Založba Obzorja, Maribor.

12. Miloševice, Novak, 1989: Projektovanje istraživanja u ratnoj veštini, Vojnoizdavački $i$ novinski centar, Vojna štamparija, Beograd.

13. Možina, Stane, et al.,1994: Management, Didakta, Radovljica, Ivanko, Štefan: poglavje 10 - Osnove organiziranja in poglavje 11 - Projektiranje organizacije, str. 373-438.

14. Opis modela za podporo pri strateškem odločanju-DRMM, 1999: Generalštab Slovenske vojske - uredil Dobran Božič, Ljubljana.

15. Rozman, Rudi, et. al., 1993: Management, Gospodarski vestnik, Ljubljana.

16. Savšek, Tomaž, 2000: Sodobni vojaški simulacijski sistemi-operacijske raziskave, vojne igre in bojne simulacije, Generalštab Slovenske vojske, Center vojaških šol, Delo Tiskarna, Ljubljana.

17. Sikavica, Pere, 1991: Modeliranje organizacijske strukture poduzecea, Informator, Zagreb.

18. Šteiner, Alojz, 2000: Preoblikovanje strukture sil Slovenske vojske - študija primera, Zaključna naloga, Poveljniško-štabna šola, Generalštabni program, Ljubljana.

19. The official Dictionary of military terms, second edition 1997: Department of defense, USA, The joint chiefs of stab, Global professional publications, Washington, D.C. 
20. The TASCFORM methodology, 2000: A technique for assessing comparative force modernisation (seventh edition), The office of the assistant secretary of defense, USA, The Analytic Sciences Corporation (TASC), Arlington, Virginia.

21. Vila, Antun: Reinženiring - nova organizacijska revolucija, Gospodarski vestnik, št. 28 , 29 in 30, julij 1997. 


\title{
RUDOLF MAISTER - STRATEŠKI VODJA
}

\author{
RUDOLF MAISTER - \\ STRATEGIC LEADER
}

Povzetek Major Rudolf Maister je leta 1918 samoiniciativno prevzel vojaško poveljstvo v Mariboru in na spodnjem Štajerskem. S tem dejanjem je odločilno posegel v dogajanja v severovzhodni Sloveniji po koncu prve svetovne vojne. Dobesedno čez noč se je povzpel s taktične na strateško raven poveljevanja. Na podlagi teoretičnega modela učinkovitega vodje na strateški ravni in njegovih dejanj od leta 1918 do 1919 je bila opravljena analiza njegovih sposobnosti. V članku avtor utemelji osebnostne lastnosti, motive in sposobnosti Rudolfa Maistra, ki upravičujejo njegovo naglo napredovanje od majorja do generala.

Ključne Maister, general, strateški vodja, voditeljske sposobnosti.

besede

Abstract In 1918, Major Rudolf Maister took over military command in Maribor and in southeastern Styria on his own initiative. This had a decisive impact on the events in northeastern part of Slovenia after WWI. Literally over night, he was promoted from a commander at the tactical level to the strategic-level commander. A theoretical model of an efficient leader at the strategic level and his acts from 1918 to 1919 served as a tool for the analysis of his ability. The article outlines the character features, motives, and ability of Rudolf Maister, which justify his accelerated promotion from Major to the rank of General.

Key words Maister, general, strategic leader, leadership skills.

Uvod Major Rudolf Maister je 1. novembra 1918 samoiniciativno prevzel vojaško poveljstvo v Mariboru in na spodnjem Štajerskem. S tem dejanjem je odločilno posegel v dogajanja v severovzhodni Sloveniji po koncu prve svetovne vojne. 
Dejanje, ki je pomenilo začetek njegovega prehoda s taktične na strateško raven odločanja, je formalno potrdil slovenski Narodni svet za Štajersko s podelitvijo generalskega čina. ${ }^{1}$ Podelitev čina na njegovo zahtevo ${ }^{2}$, ki je pomenila preskok dveh stopenj v napredovanju, je bila predmet negodovanj in razprave $\mathrm{v}$ tedanji Narodni vladi za Slovenijo v Ljubljani ter kasneje v Ministrstvu za vojsko in mornarico v Beogradu, to pa je verjetno vplivalo na njegovo predčasno upokojitev.

Kateri motivi in sile so gnali majorja, da prevzame pooblastila in odgovornosti, ki so bila nad njegovim položajem in činom? Katere so bile njegove osebnostne lastnosti in sposobnosti, ki so mu omogočile preskok na strateško raven odločanja? Končno, ali je Rudolf Maister izpolnjeval zahteve, ki opredeljujejo strateškega vodjo - generala?

\section{KAJ NAREDI DOBREGA GENERALA?}

Teorij o potrebnih voditeljskih sposobnostih oseb na vodilnih dolžnostih je precej in se pomembneje ne razlikujejo ne glede na to, ali gre za vojaško ali civilno organizacijo. V vojaških teorijah obstajajo različni pogledi na ključne sposobnosti, ki jih mora imeti poveljujoči na najvišjih ravneh poveljevanja. Ena od teh pravi, da dobrega generala odlikujejo intelekt, energija, nesebičnost in humanost. ${ }^{3}$

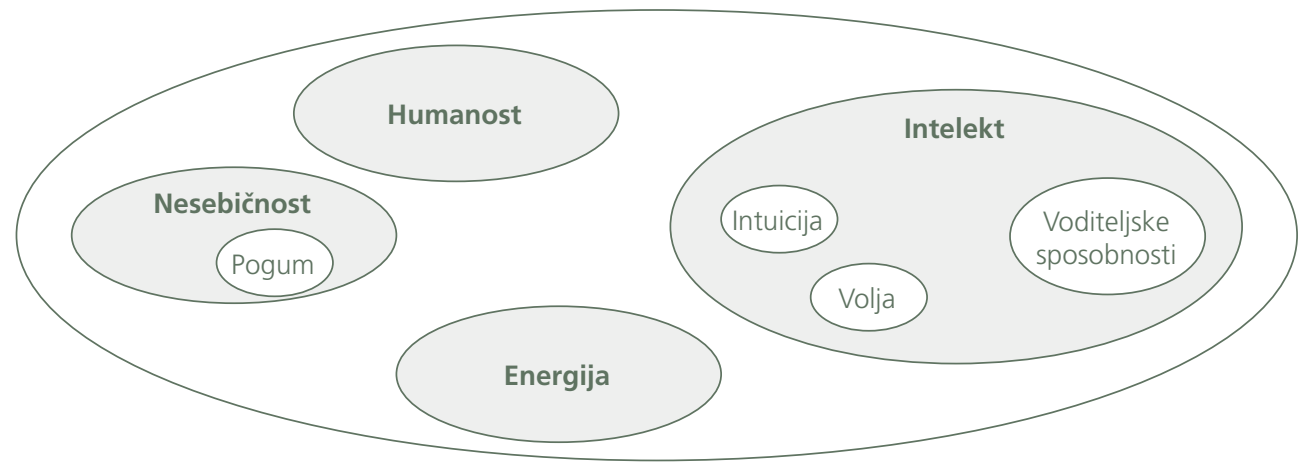

Iz intelektualnih sposobnosti izhajajo sposobnosti, ki so neposredno povezane s temeljno funkcijo poveljevanja, $\mathrm{z}$ odločanjem. To so voditeljske sposobnosti, intuicija in volja. Energija je temeljni pogoj učinkovitega poveljevanja, ki je neprekinjen proces in omogoča poveljniku delovanje v kritičnih razmerah, ko je njegova odločitev najpomembnejša. Pomeni biti vedno na kritični točki ob kritičnem

\footnotetext{
Hartman, Bruno, Rudolf Maister - general in pesnik (Ljubljana: DZS, 1998), str. 43.

»Za rešitev velike in težke naloge, ki sem si jo sicer naprtil sam, sem moral torej imeti tako visok vojaški čin, da bi mi zagotovil med civilnim prebivalstvom splošen ugled, med vojaštvom - tudi z razrahljano disciplino - pa slepo pokorščino. «Ibid., str. 42.

3 Meigs, C. Montgomery, Generalship: Qualities, Instinct and Character (PARAMETERS, Summer 2001. Carlisle: U.S. Army War College, 2001).
} 
času. Iz nesebičnosti izhaja poveljnikov pogum. Dober poveljnik ne razmišlja o svoji usodi, ko mora sprejemati težke odločitve. Odnos do podrejenih, občutek povezanosti, zavedanje, da po nepotrebnem ne izpostavlja njihovih življenj ali od njih pričakuje, da bodo storili nemogoče, so jedro njegove humanosti. Poveljnikova energija, nesebičnost in humanost omogočajo uspešno izvajanje ene od nalog pri vodenju - motiviranje.

\section{VODITELJSKE SPOSOBNOSTI}

V skupini prej omenjenih sposobnosti, ki razlikujejo dobrega generala od povprečnih, so v večini tiste, ki so prirojene ali pridobljene z vzgojo (intuicija, volja, humanost, nesebičnost). To seveda ne pomeni, da se nekdo mora obvezno roditi za dobrega generala, so pa dedne lastnosti vsekakor zelo pomembne. Na drugi strani so voditeljske sposobnosti tiste, ki odločilno dajejo podlago za učinkovito izvajanje poveljniških funkcij. Čeprav so neposredno odvisne od prirojenih intelektualnih sposobnosti, pa se v popolnosti razvijejo z izobraževanjem, usposabljanjem in poveljniškimi izkušnjami.

Pod pojmom voditeljske sposobnosti razumemo znanje, veščine, lastnosti in druge sposobnosti, ki omogočajo poveljniku izvajanje njegovih funkcij. Zasnovo jim daje ustrezna izobrazba, v vojaški organizaciji pa se dokončno razvijejo na podlagi znanja in izkušenj vodenja enot ter strokovnega izpopolnjevanja med vojaško kariero. Vsekakor uspešno vodenje enot na nižjih ravneh ne pomeni, da bo poveljnik samodejno uspešen tudi na najvišji - strateški ravni. Strateško okolje zahteva sposobnosti, ki jih lahko razdelimo v tri kategorije: konceptualne, tehnične in medosebne ( $\mathrm{v}$ angl. orig. interpersonalne) ${ }^{4}$.

Konceptualne sposobnosti pomenijo sposobnost razumevanja in delovanja $\mathrm{v}$ zapletenem, spremenljivem in »neotipljivem« strateškem okolju. Vključujejo poznavanje dejavnikov strateškega okolja in njihovo medsebojno povezanost, celovito in večdimenzionalno ukvarjanje s problemi ter sposobnost oblikovati in posredovati strateške cilje in koncepte. Vodja, ki ima konceptualne sposobnosti, zna oblikovati elemente strategije: strateške cilje, metode in sredstva, strateške usmeritve, koncept ter težišče delovanja za njeno uresničitev.

Tehnične sposobnosti vključujejo razumevanje vojaškega sistema ter njegovo povezanost s političnim, z ekonomskimi, družbenimi in drugimi sistemi. Vodja, ki ima tehnične sposobnosti, razume svojo vlogo v strateškem okolju, zahteve in omejitve, ki mu jih ta nalaga, ter pričakovanja drugih subjektov zunaj vojaškega sistema. Je sposoben sodelovati pri oblikovanju varnostne politike, pripravi vojaške strategije in zagotovitvi virov za njeno uresničitev. Položaj od njega zahteva tudi uspešno komuniciranje z zakonodajno in izvršno vejo oblasti. Medosebne sposobnosti vključujejo sposobnost doseganja soglasja v lastni organizaciji in

4 Strategic Leadership Primer (Carlisle: U.S. Army War College, 1998), str. 37. 
sposobnost pogajanja z zunanjimi subjekti. Sposoben vodja zna pridobiti podporo ali soglasje vodij zunanjih organizacij za uresničevanje lastne strategije. Je prepričljiv posredovalec argumentov, spoštuje zahteve in pričakovanja drugih vodij, zna jasno izraziti stališča in odločno zastopa cilje svoje organizacije. Vendar zna sklepati kompromise. Sposobnost komuniciranja z zunanjimi subjekti (vladne in nevladne ustanove, parlamentarni odbori, javnost ipd.) je še posebej pomembna za izvajanje temeljnih nalog, ki jih ima strateški vodja, in to ga razlikuje od vodij na nižjih ravneh v organizaciji.

\section{NALOGE STRATEŠKEGA VODJE}

Od vodje na strateški ravni se pričakuje, da določi vizijo organizacije, oblikuje organizacijsko kulturo, komunicira z zunanjimi organizacijami in ustanovami na nacionalni ravni, predstavlja svojo organizacijo ter vodi in upravlja spremembe. ${ }^{5}$ Določitev vizije je temeljna naloga strateškega vodje. Je podlaga za oblikovanje dolgoročnih načrtov in strategij za njeno uresničitev. Vizija daje dolgoročno smer ali orientir za razvoj oziroma stanje organizacije. S sprejetjem strategije vizija dobi »oprijemljive« okvire.

Oblikovanje organizacijske kulture je temeljni pogoj učinkovitega uresničevanja strategije. Ustrezno organizacijsko kulturo strateški vodja doseže z razvijanjem skupnih vrednot, informiranjem o ciljih organizacije, viziji in strategiji ter gradnji konsenza in s kadrovanjem.

Odnosi z zunanjimi organizacijami in ustanovami vključujejo razumevanje ciljev organizacije ter vzpostavitev konsenza za podporo njihove uresničitve. Proces je dvosmeren in nalaga strateškemu vodji, da razume cilje drugih. Posebej pomemben je pri oblikovanju vojaških koalicij ali medresorskem usklajevanju izvajanja nacionalnovarnostne politike. $\mathrm{V}$ odnosih na nacionalni ravni mora biti strateški vodja sposoben, da sodeluje pri oblikovanju političnih usmeritev za razvoj in uporabo vojske ter definira potrebne vire za njihovo izvajanje. V svoji organizaciji je odgovoren, da podrejeni razumejo nacionalnovarnostno politiko. Njegova naloga je, da izdaja usmeritve in naloge za njeno uresničevanje.

Strateški vodja je v komunikaciji z zunanjim svetom predstavnik svoje organizacije. Od njega se pričakuje, da pozna in razume nacionalne interese, vrednote in kulturo, medsebojno povezanost političnega, ekonomskega, vojaškega, psihološkega in drugih stebrov nacionalne moči. Mora poznati vlogo vojske v sistemu nacionalne varnosti ter jo ustrezno zastopati. Navsezadnje se nobena sprememba na strateški ravni ne dogaja spontano. Upravljanje sprememb vključuje definiranje potrebnih virov, pripravo načrtov in strategij, organiziranje sil, dodeljevanje nalog in virov, razvijanje metodologij, kadrovanje ter druge ukrepe. Razumevanje posrednih in neposrednih učinkov sprememb je osnova učinkovitega upravljanja. Oblikovanje

\footnotetext{
5 Strategic Leadership Primer, str. 45.
} 
Slika 2: Voditeliske sposobnosti

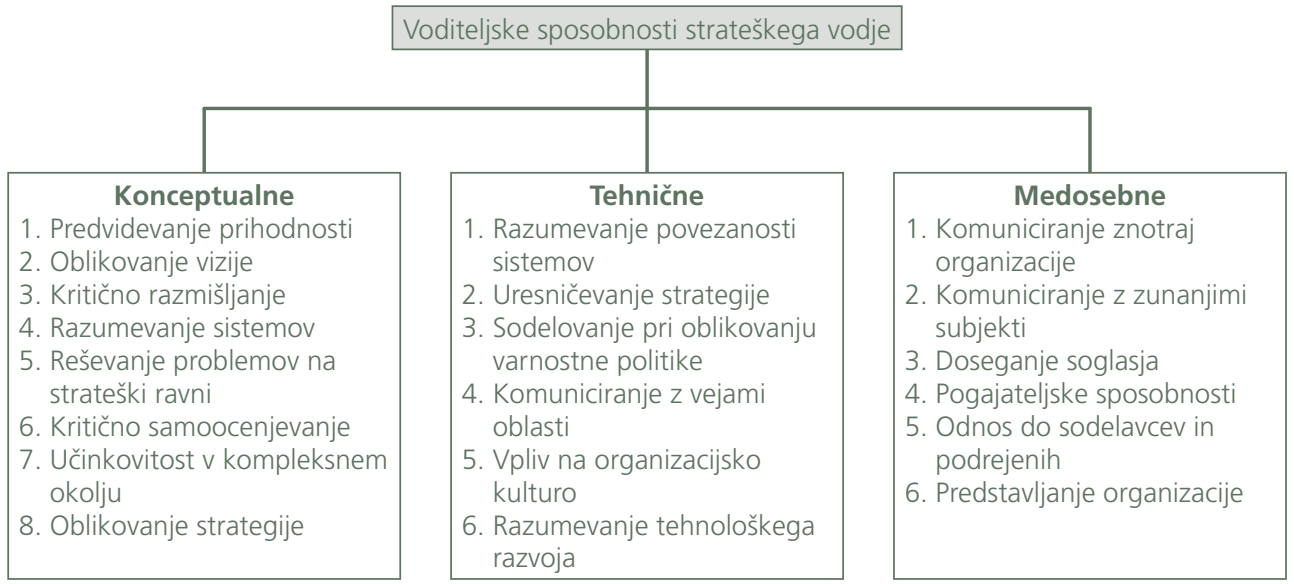

organizacijske kulture je pomoč pri uspešnem upravljanju sprememb, saj omogoča, da organizacija prevzame cilje vodje, se z njimi poistoveti ter podpira prizadevanje za njihovo doseganje. Sestavni del upravljanja sprememb je dodeljevanje pooblastil vodjem na nižjih ravneh ter vzpostavitev učinkovitega pridobivanja povratnih informacij o uresničevanju strategije.

\section{RUDOLF MAISTER - VODJA, JUNAK, DOMOLJUB}

Kakšen človek je bil Rudolf Maister? Iz pripovedovanj njegovih sodobnikov je na sogovornika ali poslušalca naredil izreden vtis že ob prvem stiku. ${ }^{6}$ Znal je spretno komunicirati z ljudmi in jih pridobiti, da so mu sledili. Že med šolanjem so ga opisovali kot moža trdnega značaja, dobrodušnega in mirnega. Kasneje je pokazal, da zna biti odločen, oster in tudi brezkompromisen, še posebej v akcijah proti nemškim nacionalistom ali ko je bilo treba zagotoviti red in disciplino. Odlikovala ga je izjemna delovna energija. Vedno je bil na kraju dogodkov, ko je bilo kritično in je moral osebno odpraviti grožnje uresničevanju njegovih načrtov.

Poseben je bil Maistrov odnos do podrejenih. Imel je posluh za navadnega vojaka. Od svojih podrejenih je veliko zahteval, vendar ni pričakoval, da bodo storili nemogoče. Znal jih je motivirati. O motivatorskih sposobnostih pričata dogodka na mariborski železniški postaji, ko je vračajoče se vojake z vzhodne fronte, slovenske in srbske narodnosti, prepričal, da so sestopili z vlaka in se pridružili njegovi vojski. Dr. Anton Trstenjak je zapisal, da so njegovi podrejeni videli in hoteli videti v svojem generalu poosebljene vse vojaške vrline in odlike. ${ }^{7}$ Njegov pribočnik je opisal naslednje Maistrove lastnosti: neustrašnost, ki ne klone pred nobeno nevarnostjo, prisebnost,

\footnotetext{
")... Segli smo v roke častniku, ki se nam je že po svoji visoki, zravnani postavi in po prodorni sili svojih oči, po svojih lepih brkih in tudi po žametno zveneči gorenjščini zazdel kot nekakšna izredna in prav junaška osebnost.« Hartman, str. 123.

Hartman, str. 9.
} 
ki obvlada še tako nepričakovan položaj, borbenost, ki ne ljubi ovinkarskih kompromisov, iniciativnost, ki se ne boji osebne odgovornosti, in organizatoričnost, ki strogo usmerja vsako delo. ${ }^{8}$

O tem, da je bil Rudolf Maister pogumen človek, ne dvomi verjetno nihče. Samoiniciativno prevzeti osebno odgovornost za odločanje o usodi drugega največjega slovenskega mesta ter poteka prihodnje meje države v nastajanju, izjaviti pred zborom avstrijskih visokih častnikov, da prevzema poveljevanje, to ne govori samo o njegovem moralnem in fizičnem pogumu, ampak tudi o njegovi sposobnosti oceniti razmere, predvideti razvoj dogodkov ter oceniti reakcije njegovih nasprotnikov. Odločnost, drznost in požrtvovalnost so bile stalnice njegovega delovanja.

Maistrovi kritiki so poudarjali njegovo ostrino, impulzivnost, nepremišljenost in individualizem. Vendar, kot ugotavlja dr. Bruno Hartman, so bile njegove odločitve v okvirih vojnega prava, ki je bilo v rabi v tistem času. Postavljanje oblasti v nastajajoči državi ter oblikovanje slovenske vojske, neredi ob postankih vlakov s povratniki z bojišč prve svetovne vojne, pomanjkanje, kriminal, boji z nemškimi nacionalisti in četami ter omahljivo slovensko politično vodstvo so narekovali hitre, drzne in učinkovite odločitve. Veliko alternativ in časa ni bilo na voljo. Pri sprejemanju odločitev je res velikokrat ravnal na lastno pest in se ni posvetoval s političnim vodstvom, vendar ga je tekoče informiral ter znal, vsaj na Štajerskem, pridobiti njegovo naklonjenost in odobravanje. Svojih napak se je zavedal in jih je znal popraviti. Tako je na primer preklical odredbo, s katero je grozil izbranim meščanom (talcem), če ne bodo prenehale grožnje njegovemu življenju. ${ }^{9}$

Od kod je major Rudolf Maister črpal energijo in pogum, da si je naprtil breme odgovornosti, veliko večje od njegove tedanje dolžnosti? Dr. Hartman ugotavlja, da je imela Maistrova akcija korenine v njegovi duhovni zasidranosti v življenju slovenskega naroda skozi stoletja. ${ }^{10}$ Nedvomno je bil Maister velik Slovenec. Čutil se je povezanega s slovenskimi ljudmi in zavezan slovenski zemlji. Zaradi domoljublja in pokončne drže je bil večkrat kaznovan, vendar je ohranil neomadeževano častniško podobo. V omahovanju slovenskega političnega vodstva in akcijah nemških nacionalistov je videl možnost in dolžnost, da s svojimi dejanji prispeva $\mathrm{k}$ uresničitvi teženj slovenskega naroda, nazadnje izraženih na zasedanju avstrijskega državnega zbora na Dunaju 30. maja 1917 (majniška deklaracija).

\section{MAISTROVE VODITELJSKE SPOSOBNOSTI}

Major Rudolf Maister je ocenil politične razmere ob koncu prve svetovne vojne na prostoru nekdanje habsburške monarhije. Ob njenem razpadu se je nenadoma skupini manjših narodov ponudila priložnost za samoopredelitev in vzpostavitev

\footnotetext{
8 Hartman, str. 123.

9 Hartman, str. 68.

10 Hartman, str. 127.
} 
lastne države. Sposoben kritičnega razmišljanja je spoznal, da je prišel trenutek, ki se zgodi enkrat v tisoč letih. Trenutek, ki je zahteval preudarnost in takt, toda tudi odločen odgovor na zapletene in negotove vojaškopolitične razmere. Verjetno se je zavedal, da glas malega naroda ne bo pomenil veliko pri odločanju o razdelitvi ozemelj med zmagovalci vojne, čeprav ni mogel vedeti, da je v tajnem londonskem sporazumu že bila dogovorjena razdelitev ozemelj habsburške monarhije. Brez jasnih političnih usmeritev je sledil viziji Združene Slovenije, rojene v pomladi narodov leta 1848. Spoznal je kritičnost trenutka za doseganje strateških nacionalnih ciljev. Trenutek za akcijo, odgovor na razvijajočo se situacijo; akcijo, ki jo lahko izpelje samo vojaška organizacija. Sposobnost, da kritično oceni razmere in predvidi dogodke, je Maistru omogočila, da je z učinkovitimi potezami vedno prehitel nasprotno stran. Tako je zadnji trenutek prevzel vojaško oblast v Mariboru in je $\mathrm{z}$ razorožitvijo nemške varnostne straže (Shuztwehra) pravočasno prehitel avstrijske namere. V zapletenih razmerah ni razmišljal samo v okviru vojaške stroke, temveč celovito in večplastno (postavitev politične oblasti, oblikovanje lastnih oboroženih sil, razvoj slovenske kulture in gospodarstva). Ves čas je nadzoroval spremembe in ni dovolil, da bi dogodki vodili njega.

Kritiki Maistru zamerijo, da je »uhajal« političnemu nadzoru. Res je večkrat ukrepal na svojo roko, včasih tudi prekoračil pooblastila, čeprav je vsaj s štajerskim Narodnim svetom vzdrževal dobre odnose in si pridobil njegova pooblastila ali odobritev za posamezne ukrepe. Na drugi strani ni bilo plodnega odnosa z omahljivo ljubljansko vlado, ki se je bolj zanašala na pogajanja kot uporabo vojske. Nikakor pa ne moremo trditi, da je deloval samostojno, zunaj političnega okvira. Navsezadnje je dobil tudi podporo francoskega poveljstva za jugovzhod v Beogradu. ${ }^{11}$ Vsekakor je bil vešč komunikacije v vojaškem in političnem strateškem okolju.

Maister je vizijo prevzel od predhodnikov, zastopnikov ideje Združene Slovenije. Razvil pa je strategijo za njeno uresničitev. Čeprav formalno ni bila zapisana, lahko njeno uresničevanje spremljamo skozi Maistrove odločitve. Kot po strateškem načrtu si dogodki sledijo v logičnem zaporedju: prevzem vojaške oblasti, postavitev politične oblasti, oblikovanje vojske, razorožitev nasprotnika, zasedba in obramba mej itn. Že z dogodki v Mariboru je pokazal, da se za uresničitev nacionalnih ciljev ne naslanja samo na uporabo vojske, temveč krepi tudi druge stebre nacionalne moči: političnega, ekonomskega, psihološkega (volja naroda). Dokončno se je njegovo zrelo delovanje v strateškem okolju potrdilo na Koroškem v coni A, ko je po doseganju vojaških ciljev težišče delovanja usmeril v politično in kulturno povezanost koroških Slovencev. Uspešno je usklajeval vse dejavnosti na političnem, kulturnem in gospodarskem področju ter ustvarjal pogoje za zmago na plebiscitu. Zagotovil je enotno vojaško in civilno prizadevanje. Vprašanje je, kakšen bi bil izid plebiscita, če bi ostal na Koroškem. ${ }^{12}$ Maistrove komunikativne sposobnosti so bile večkrat omenjene. Vendar ni bil le spreten in prepričljiv

"I Times Books, The Times Atlas of World History, Third edition (London: Harper Collins Publisher, 1989), str. 310 .

${ }_{12}$ Tri tedne pred plebiscitom je moral oditiv Beograd in tam so ga zadržali dober mesec. Hartman, str. 82. 
govorec. Za uresničevanje svoje strategije je uporabljal tudi diplomatske spretnosti. Izkazal se je kot spreten pogajalec, zlasti z vojaškimi osebami. ${ }^{13}$ Znal je iztržiti kar največ ugodnosti zase. Čeprav je bil odločen in trd pogajalec, je vedel, kdaj mora popustiti, da ne bi ogrozil dolgoročnejših ciljev. Tako kot tedaj, ko je popustil pri ustanovitvi nemške varnostne straže - Shutzwehra, da bi pridobil čas in okrepil vojsko. Nekatere odločitve se zdijo nagle in brezkompromisne, vendar je večinoma ukrepal previdno in preudarno, da ne bi sprožil nasprotnih reakcij, ki bi lahko ogrozile njegove načrte. Na svoji poti je pazil, da ne bi po nepotrebnem ustvarjal novih sovražnikov. Znal je tudi gladiti spore, kot na primer ob stavki železničarjev. Maistrove strategije seveda ne bi bilo možno uresničiti brez podpore slovenskih vojakov in uradnikov, duhovništva, političnega vodstva ter zavednih Slovencev na Štajerskem in Koroškem. Uspelo mu je, da so sledili njegovi viziji in pomagali pri uresničevanju njegove strategije. Pri oblikovanju slovenskih enot je uspešno izkoristil bojne izkušnje in moralo udeležencev prve svetovne vojne, njihovo navdušenje in lojalnost domovini. V slovenskem človeku je po dolgem tisočletju zbudil spoštovanje poguma, odločnosti, bojevitosti in navdihnjenega delovanja za slovensko državnost. ${ }^{14}$

Sklep Rudolf Maister je bil velik Slovenec, dober general in učinkovit strateški vodja. Njegove sposobnosti in njegova dejanja potrjujejo, da mu je Narodni svet za Štajersko upravičeno podelil čin generala. Nobenega dvoma ni, da je izpolnjeval merila, po katerih bi danes ocenjevali sposobnosti vodje na strateški ravni. Imel je vizijo, ki je izhajala iz tisočletne narodove želje po združeni in samostojni državi. Znal je kritično ocenjevati in se prilagajati strateškemu okolju, določati dosegljive strateške cilje ter učinkovito izrabiti razpoložljive vire pri uresničevanju svoje strategije. Njegove voditeljske sposobnosti, intuicija, volja, pogum, nesebičnost in humanost so mu omogočili uspešno delovanje $\mathrm{v}$ zapletenem in negotovem strateškem okolju. Okolju, v katerem je uporaba vojaške sile le eden, čeprav včasih odločilen dejavnik za doseganje nacionalnih ciljev. In ravno sposobnost usmerjati in usklajevati vojaški dejavnik z ekonomskim, diplomatskim, s kulturnim, političnim in z drugimi dejavniki dokazujejo, da je intelektualno prerasel organizacijsko raven, na kateri je deloval do 1. novembra 1918. Rudolf Maister potrjuje, da učinkovitega generala - strateškega vodjo naredijo njegove intelektualne sposobnosti, energija, odnos do podrejenih ter voditeljske sposobnosti in ne le formalna karierna pot.

\footnotetext{
13 Hartman, str. 125.

14 Hartman, str. 125.
} 
1. Hartman, Bruno, Rudolf Maister - general in pesnik. Ljubljana: DZS, 1998.

2. Meigs, C. Montgomery, Generalship: Qualities, Instinct and Character. PARAMETERS, Summer 2001. Carlisle: U.S. Army War College, 2001.

3. Pavlovič, K. Stevan, Yugoslavia. New York, Washington D.C.: Praeger Publisher, 1971.

4. Randburg Corporation Ltd. Famous Slovenes. Dosegljivo na internetu, 12. 8. 2000: $<$ http://www.randburg.com/si/general/slo8.html.

5. Singleton, Fred, Twentieth-Century Yugoslavia. New York: Columbia University Press, 1976.

6. Strategic Leadership Primer. Carlisle: U.S. Army War College, 1998.

7. Times Books, The Times Atlas of World History, Third edition. London: Harper Collins Publisher, 1989. 


\section{O RAZVOJU SLOVENSKE VOJSKE}

\section{ABOUT THE DEVELOPMENT OF THE SLOVENIAN ARMED FORCES}

Povzetek Avtor v članku pregledno obravnava nastanek in razvoj Slovenske vojske, njeno vlogo v slovenski osamosvojitvi in ob izzivih, ki nas čakajo ob vključitvi v Nato in EU. V prvem delu besedila obravnava vzroke, ki so povzročili razpad JLA in oblikovanje slovenskih oboroženih sil, njihov razvoj iz TO in MSNZ v Slovensko vojsko, v drugem pa razmišlja o reorganizaciji in profesionalizaciji Slovenske vojske ter njeni vlogi v spremenjenih varnostnih okoliščinah prihodnosti.

Ključne Varnostno okolje, splošni ljudski odpor, TO, MSNZ, sodobne oborožene sile, besede vojaški rok, profesionalizacija, prednostne naloge razvoja.

Abstract The author discusses in his article the foundation and development of the Slovenian Armed Forces, its role in the War for Slovenia and various challenges that our country has to cope with upon joining NATO and the EU. The first part of the article deals with the reasons for the disintegration of the Yugoslav People's Army and the formation of the Slovenian Armed Forces, their development from the Territorial Defence and National Defence Manoeuvre Structure to the Slovenian Armed Forces. In the second part, the author provides some reflections about the reorganization and professionalization of the Slovenian Armed Forces and its role in the altered future security situation.

Key words Security environment, general national resistance, Territorial Defence, National Defence Manoeuvre Structure, modern armed forces, military conscription, professionalization, development priorities. 


\section{VLOGA OBOROŽENIH SIL}

Clausewitzeva ugotovitev, da je vojna podaljšana roka politike in vojska njeno orodje, njeno sredstvo za doseganje političnih ciljev, je danes še kako očitna $\mathrm{v}$ razvitih demokratičnih državah. Združene države Amerike so dober primer, nekdanji predsednik združenega štaba vodi zunanjo politiko, ameriška vojska pa zagotavlja in brani ameriške zunanje interese (National Security Strategy for a Next Century - NSS, October 1998, White House, ZDA). Nič drugače ni v Ruski federaciji, Francozi, Belgijci in drugi ravnajo podobno. Dolga tradicija in relativno dolga samostojnost sta jasno oblikovali gospodarski in politični interes in temu primerno vojaško organizacijo, z jasno zapisano vizijo vojaškega razvoja in opredeljenimi nalogami. Potrebam in interesom primerno organizirajo, opremljajo, usposabljajo in uporabljajo svoje orodje - vojsko (NSS). Nekdanja skupna država Jugoslavija je pri razvoju in uporabi svoje vojske ravnala podobno. Politično vodstvo je $v$ blokovski delitvi sveta krmarilo med vzhodom in zahodom, njegov glavni cilj je bil ostati na oblasti. Temu primerno so razvijali obrambno in vojaško strategijo ter vojaško doktrino in taktiko. Kmalu po ustanovitvi države so poslali svojo vojsko na mirovno operacijo na Bližnji vzhod, kar je bilo skladno s političnimi ambicijami (pozneje neuvrščenost) in gospodarskimi interesi države (nafta). Ob spoznanju, da samo manevrski del vojske ne bo mogel obraniti države (ugotovitve iz analize češkoslovaških dogodkov 1968) in vladajočega režima, so začeli po republikah razvijati teritorialno obrambo ter koncept splošnega ljudskega odpora in družbene samozaščite (SLO in DSZ) kot dopolnilo manevrski strukturi zvezne vojske. Izkušnje pri uporabi tega koncepta so bile že bogate, na primer Vietnam in gverilske ali partizanske organizacije, na naših tleh pa smo ga preizkusili v drugi svetovni vojni. Iračani bi to trditev dopolnili, če je njihov odpor proti Američanom organiziran, kar očitno je. Srečujejo se z bolje opremljenim, usposobljenim in izurjenim nasprotnikom, ki mu poskušajo razmere za bivanje ustvariti nevzdržne in ga tako prisiliti, da zapusti državo, kar je temeljna zamisel in ideja koncepta (splošnega) ljudskega odpora.

\section{SLOVENSKA SAMOSTOJNOST IN OBOROŽENE SILE}

Slovensko politično vodstvo in slovenska politika sta uspešno uporabila Teritorialno obrambo (TO), v letu 1990 v Sloveniji najbolj razvito, ter dodatno organizirano, opremljeno in usposobljeno Manevrsko strukturo narodne zaščite (MSNZ). Brez velikih bitk, kot je bila na primer pri Kursku, vendar s spretnostjo najboljših vojskovodij, je bila dosežena slovenska samostojnost. In po Clausewitzu uporabimo vojsko in vojaško silo, ko doseganje zastavljenega političnega cilja po politični poti ni mogoče, in jo umaknemo, ko je diplomatska pot spet odprta oziroma ko je nasprotnik v položaju, da se mora (in hoče) pogovarjati na nam sprejemljiv način. Samostojnost je bila davni sen slovenskega naroda, politično vodstvo je ta cilj skušalo doseči po mirni poti, ker pa je bilo neuspešno, so TO, Policija (Milica) ter civilna obramba uspešno izpolnile svojo nalogo. 
V naši osamosvojitveni vojni so bitke in boji potekali po konceptu splošnega ljudskega odpora, z uporabo posameznih načel in prvin partizanskega bojevanja: predvsem po načelu »udari in se umakni«. Frontalne oblike oboroženega boja nismo uporabili. Številčno sicer močnejši, vendar tehnično podrejeni, bitke prsi ob prsi na odprtem prostoru nismo mogli sprejeti. Tudi večje koncentracije TO na majhnem prostoru nismo smeli uporabiti, premoč v zraku je bila prevelika. Obe strani sta spoštovali načelo minimalne uporabe sile, obema je bilo na voljo več ljudi in sredstev za vojaški spopad, kot sta jih dejansko uporabili (besede poveljnika 7. pokrajinskega štaba TO Maribor v začetku julija 1991: »Napad na sedanjo Vojašnico generala Maistra bi povzročil preveč smrtnih žrtev«). Lahka in v primerjavi z jugoslovansko armado zastarela pehotna oborožitev nam marsičesa ni omogočala, premike sovražnika smo na primer ovirali na različne načine, tudi s sredstvi iz popisa. Sestrelili smo dva helikopterja, letala pa so bolj ali manj neovirano in neopaženo letala nad našimi glavami, zračnega prostora nismo obvladovali. S pravilnimi odločitvami in s pravim občutkom za realnost smo dosegali vojaške zmage. Zmagali bi tudi, če bi preostanek Jugoslavije in jugoslovanska armada uporabila vsa razpoložljiva sredstva, gotovo pa bi to zmago plačali z več žrtvami in večjo škodo.

Republika Hrvaška se je za svojo samostojnost morala boriti nekaj let. Dolgo je organizirala, opremljala in predvsem usposabljala svojo vojaško organizacijo (ter čakala na primeren politični trenutek). Izdatki so bili neprimerljivo večji, veliko več poklicnih in rezervnih vojakov je bilo treba za oblikovanje učinkovite vojske, ki je uspela s svojega ozemlja izriniti oziroma v operaciji Nevihta premagati (krajinsko) srbsko (jugoslovansko) armado. Uresničitev zastavljenega cilja, samostojnosti in suverenosti ali vojaškopolitične zmage, pa v večini primerov odpira vprašanje prevelike (v minuli vojni sicer nujne) in za neko prihodnjo vojno neustrezno organizirane vojske. Večina držav, tudi Slovenija, se je po vojni srečala z zmanjšanjem obrambnih izdatkov, odpuščanjem oziroma demobilizacijo vojske in modernizacijo. Mnoge države se ukvarjajo s socialnimi problemi in različnimi sindromi, ki so posledica oboroženih bojev (Vietnam, Irak 1991, Kosovo). Posamezne države in oborožene sile so to vprašanje reševale vsaka na svoj način, drugače od drugih. Samo Slovenija pa je po vojaški zmagi začela graditi svojo vojsko.

\section{SPREMEMBE VARNOSTNEGA OKOLJA}

Po padcu berlinskega zidu so se varnostne razmere v svetu zelo hitro spreminjale. Nevarnost jedrskega spopada svetovnih razsežnosti se je zmanjšala, gospodarsko in vojaško tekmovanje je preživela le ena svetovna sila, globalizem je prinesel skoraj trenutne povezave in obilje informacij o dogajanju v svetu, zelo se je razvil organiziran kriminal, pojavil se je terorizem. Delitev sveta se je, če priznamo ali ne, začela tudi po verskem prepričanju, Kitajska bo s svojo ekonomsko rastjo in vesoljskimi poleti začela uveljavljati vse večji politični vpliv. Zelo verjetno se bo v »nezanesljivi prihodnosti« (Preparing for an Uncertain Future, NSS) oblikovalo več različnih regionalnih centrov gospodarske, politične in vojaške moči. V blokovski delitvi sveta je bilo popolnoma jasno, kdo in kje je nasprotnik, nenadoma pa 
tradicionalnega, klasičnega nasprotnika ni lahko identificirati. Stvarni in zaznani občutek naše varnosti sta se s prepričanostjo, da vojna v evropsko-ameriškem prostoru ni več mogoča oziroma da je malo verjetna, zelo povečala. Zmanjšuje se občutek vojaške ogroženosti, povečuje pa zaznavanje ogroženosti zaradi mednarodnega terorizma, organiziranega kriminala ...

Že v letih 1995 in 1996 je bilo vojaško in varnostno okolje za Slovenijo zelo spremenjeno. Do takrat smo poslušali streljanje na fronti v Karlovcu, samo lučaj od naše državne meje v Beli krajini, in gledali posnetke grozot iz Bosne in Hercegovine $(\mathrm{BiH})$, navsezadnje smo imeli tudi veliko število beguncev iz teh republik in smo vsak dan poslušali opise bojev na domnevnih vojaških frontah. Tudi mi smo se še počutili vojaško ogroženi. Oddahnili smo si, ko sta se vojna in nam osovražena armada po hrvaški operaciji Nevihta preselili daleč od naših meja, ni pa nam bilo vseeno za strahote, ki so se dogajale, in umiranje prebivalcev BiH, ki so bili še zmeraj v vojni. UNPROFOR (United Nations Protection Force), pozneje SFOR (Stabilization Force) je tudi nam zmanjšal občutek ogroženosti in povečal dejansko in zaznavno varnost. V letu 1997 smo mednarodnim enotam v BiH tudi sami prispevali letalskohelikopterski oddelek, ki naj bi pomagal zagotavljati mir v tej regiji. Za to dejanje smo imeli najmanj dva razloga, želeli smo mir v sosednjih državah, na $\mathrm{BiH}$ pa nas veže tudi izrazit gospodarski interes, zato smo s to regijo oziroma državo želeli nadaljevati gospodarsko in druge oblike sodelovanja.

Leta 1997 se je "porušila« albanska država; veliko Albancev živi v Sloveniji in zato so razmere v Albaniji spreminjale tudi našo varnostno situacijo. Z mednarodno skupnostjo smo sodelovali pri vzpostavljanju miru in obnovi države, hoteli smo biti del skupnosti, ki ji ni vseeno za mir v tem delu sveta in v tej regiji, posredno pa smo želeli ščititi tudi naše gospodarske interese. Vse v vojno na balkanskih bojiščih vpletene strani so uporabljale koncept splošnega ljudskega odpora. Poznavalcu ni bilo težko prepoznati kar celih odstavkov Strategije splošnega ljudskega odpora in družbene samozaščite ter Strategije oboroženega boja. Vsa sredstva in posamezniki, v civilu ali uniformi, vse je bilo uporabljeno v teh bitkah. Kdor ni bil »z nami«, je bil »proti nam« in ga je bilo treba v poduk drugim pravočasno umakniti. Podobno taktiko je mogoče opaziti v Iraku, likvidacija »domačih izdajalcev, ki sodelujejo z okupatorjem«, ni v svetu nič neznanega. Ljudi je treba prestrašiti, da bodo z nami, ali pa vsaj ne bodo sodelovali z okupacijsko vojsko. Vojakova dolžnost je pasti za domovino, posameznik ne šteje veliko. Posledice takega koncepta vojne smo čutili in čutimo v obliki beguncev tudi v Sloveniji, število mrtvih se meri v tisočih, desetin stotisočih. Nihče ni prešteval ranjenih, poškodovanih in človeških razvalin ter razbitih družin, nastalih zaradi duševnih pretresov. Pri uporabi koncepta »vsi smo mi vojska« je pojav vojaških zločinov več kot očiten, rane v človeških dušah se zelo težko zacelijo in tudi če se, so brazgotine velike in še dolgo opazne. Mar nismo že kar prepričani, da bodo Srbi in kosovski Albanci zelo težko živeli pod isto streho?

Poznamo dve vrsti varnosti, navidezno ali zaznano, ki nam daje občutek, da živimo v varnem okolju (ogroženost pred vojno, pred naravnimi in drugimi nesrečami, 
ogroženost delovnega mesta, socialna varnost ...), in dejansko oziroma stvarno, ki nam govori o resničnem vojaškem ogrožanju z vojno, terorizmom, orožji in sredstvi za množično uničevanje, organiziranim kriminalom ... V vsej vojaški zgodovini sveta poskušajo vojaški in vojaškopolitični strategi pri morebitnem ali dejanskem nasprotniku vzbuditi vtis navidezne varnosti, da bi dosegli strateško presenečenje in lažje vojaške (in politične) zmage. Pakt o nenapadanju med nacistično Nemčijo in Stalinovo Sovjetsko zvezo je lep primer zavajanja nasprotnika. Danes se v naši državi počutimo veliko varneje kot pred leti. Skoraj ne vidimo nasprotnika, ki bi nas lahko vojaško napadel, srečujemo pa se z različnimi drugimi oblikami nevojaškega ogrožanja (potrjene v Državnem zboru in zapisane v Resoluciji o strategiji nacionalne varnosti RS, Uradni list RS, št. 56/01). Gotovo pa bomo gospodarsko, politično in kulturno uspešnejši, dosegali bomo višjo kvaliteto življenja, če bosta mir in stabilnost doma, v ožjem in širšem sosedstvu ter v svetu. Miru in stabilnosti pa ne moremo zagotavljati in zagotoviti sami, izolirani od sveta, to lahko dosežemo le skupaj z vso demokratično mednarodno skupnostjo.

Dobili smo vabilo za polnopravno članstvo v severnoatlantskem zavezništvu, od maja prihodnjega leta bomo polnopravni člani Nata in EU. Ne gre zgolj in samo za vabilo, v ta krog držav smo sami želeli, spoznali smo, da imamo s članicami zavezništva in Unije veliko skupnih interesov, da bomo na ta način vsi veliko pridobili ter da bomo laže delovali na političnem, gospodarskem in obrambno-varnostnem področju. Verjetnost, da bi nas kdo klasično vojaško ogrožal, postaja tako še manjša, občutek varnosti pa vse večji. Večina državljank in državljanov je že pozabila, da smo se komaj pred dvanajstimi leti borili za svojo samostojnost, razmer druge svetovne vojne pa se spominjajo vse bolj redki posamezniki, omenjajo jih le še zgodovinski učbeniki, vse težje pa si predstavljamo, da so tisoči slovenskih mladeničev umirali na soški in drugih frontah prve svetovne vojne. Za mir se je vredno in treba boriti, varnost je treba nekako plačati. »Vojska da, toda brez mene« je stališče, ki je precej razširjeno po Evropi, potrjeno v zadnjih raziskavah avstrijskih kolegov o odnosu civilnega prebivalstva do vojske in vojaškega poklica (okrogla miza Mladi in vojaški poklic, september 2003, Gornja Radgona). Če smo se v miru pripravljali na vojno, moramo naše stališče in misli usmeriti k pripravam v miru za zagotavljanje miru (»Si vis pacem, para pacem«, gen. Manfred Eisele, pomočnik generalnega sekretarja Združenih narodov za mirovne operacije, Celje, september 2003).

\section{ISKANJE ODGOVOROV}

Teritorialno obrambo smo razvijali za obrambo v Sloveniji in znotraj njenih meja. Posebno poglavje v naši zgodovini predstavljata razvoj Manevrske strukture narodne zaščite in njena izjemna vloga $\mathrm{v}$ pripravah in procesu osamosvajanja od maja do oktobra 1990. Zaradi namena (in načina podpore delovanja ter predvsem zaledne oziroma logistične zagotovitve) enote TO niso mogle opravljati vojaških akcij zunaj naših meja. Te enote niso mogle izvajati ofenzivnega, predvsem napadnega delovanja večjih razsežnosti. Maloštevilna stalna sestava je bila razporejena po občinskih in pokrajinskih štabih. V osnovni zamisli oblikovanja in organiziranja je imela teritorialna obramba 
s svojimi enotami predvsem dopolnilne naloge (obramba medprostorov, posameznih objektov, diverzantske in protidiverzantske naloge na začasno zasedenem ozemlju, naloge pokrivanja terena) v sodelovanju z zvezno vojsko. Občinski sekretariati so skrbeli za popise vojaških obveznikov, napotitve na služenje vojaškega roka, popis sredstev, popolnitev štabov in enot. Vsak posameznik moškega spola se je po sili zakona v določeni starosti pač moral javiti na določen naslov; določene so bile sankcije za nespoštovanje veljavnega zakona, ki so se tudi izvajale. Usposabljanje vojakov nabornikov je izvajala jugoslovanska vojska, ki je pomagala tudi pri usposabljanju enot TO. Poveljniki so bili zadolženi za usposobljenost svojih enot. Štabi TO so bili podrejeni Republiškemu štabu za TO in Republiki Sloveniji, usposobljenost in priprave za obrambo pa je preverjala tudi zvezna inšpekcija za obrambo. Odločenost, pogum in ustrezno vodenje obrambne strukture so bili kronani z vojaško zmago.

Neposredno pred vojno, še izraziteje pa po zmagi in osamosvojitvi, smo začeli sami opravljati naloge, ki pripadajo samostojni državi in njeni obrambni strukturi. Skrb za vojaško obrambo države je prevzela teritorialna obramba, opremljena z izrazito lahko oborožitvijo in opremo, zaseženo v vojni in iz popisa, organizirana in usposobljena po konceptu SLO. Drugače od drugih držav smo po vojaški zmagi in osamosvojitvi šele začeli graditi novo vojsko. Pri začetku njenega uresničevanja sta bila upoštevana dva temeljna elementa: najprej zgodovinska izkušnja pravkar minule desetdnevne vojne in seveda sovražnik oziroma nasprotnik, ki je še zmeraj nosil isto ime. Ogroženi smo se počutili doma, v svoji državi. Pripravljali smo se na obrambo na svojem ozemlju, proti znanemu nasprotniku in s svojim znanjem (skladno s konceptom SLO) smo lahko postavili samo podobno vojsko, kot smo jo že poznali. Z današnjega zornega kota gledano smo se pripravljali na vojno, ki smo jo že dobili.

V našem znanju in v novi vojaški organizaciji je manjkal marsikateri element obrambe, marsikatera komponenta vojaške moči ni bila upoštevana. Edina manevrska enota takratne vojske je bila pravzaprav brigada Moris; nastajali pa so elementi nadzora zračnega prostora, zračne obrambe, letalstva, mornarice, inženirstva, RKBO in vojaške policije. Popolnjevanje enot je potekalo po podobnem teritorialnem principu kot pred osamosvojitveno vojno in zaradi tega ter zaradi odvisnosti zaledne zagotovitve od civilne obrambe so tudi potencialno manevrske enote (na primer bataljon radiološko-kemične in biološke obrambe) postale zelo odvisne od lokalne popolnitve in tako nepremične in izrazito vezane na eno lokacijo. Znanje angleščine (predvsem specifičnih angleških vojaških izrazov) in povezljivost z drugimi vojskami sta bila kritična. Samo 15. brigada vojnega letalstva je od nastanka pri usposabljanju uporabljala angleščino in mednarodne zahteve (ICAO), popolnjena je bila s poklicno sestavo in zato smo lahko začeli mednarodno sodelovanje na enem najbolj zahtevnih področij povezljivosti. Edina nova (vojaška) naloga, ki smo se je temeljiteje lotili, je bila postavitev sistema služenja vojaškega roka in usposabljanja vojaških obveznikov za vojaško obrambo ter službo v obvezni rezervi. To usposabljanje smo leta 1994 zapisali v 37. člen Zakona o obrambi (Uradni list RS, št. 82/94) kot prvo nalogo, ki jo moramo opraviti. Njeno uresničevanje je omogočalo popolnjevanje številčno velike vojne strukture takratne vojske. 
Zmotna je misel, da obrambo po konceptu splošnega ljudskega odpora zagotavljajo vojaki naborniki, ti se usposabljajo predvsem za službo v vojni sestavi (dikcija 37. člena Zakona o obrambi: »... in usposabljanje za oborožen boj in druge oblike vojaške obrambe«), s katero vojska brani našo suverenost. To se je jasno videlo že na začetku te naloge, že prve generacije naših nabornikov v Pekrah in na Igu nismo izpostavljali ali pošiljali v vojaški spopad, nasprotno, pred jugoslovansko armado smo jih branili in varovali z rezervno sestavo (primer napada na Pekre, maj 1991). Z opustitvijo služenja vojaškega roka nismo neposredno zmanjšali naših zmožnosti za obrambo oziroma bojne pripravljenosti ali pripravljenosti vojske za bojevanje. Dolgoročno, po desetih ali dvajsetih letih, bi to seveda vplivalo tako, da za popolnitev vojnih enot ne bi imeli dovolj usposobljenih pripadnikov rezervne sestave, če koncepta vojaške obrambe ne bi spreminjali.

V kratkem času, preko noči, nismo uspeli usposobiti dovolj novih podčastnikov in častnikov za vodenje vojske, ki je narasla na približno 80000 pripadnikov. Za poveljevanje takšni vojski smo zaposlovali veliko častnikov in podčastnikov iz rezervne sestave, jih usposabljali za vodenje in jih poviševali v višje čine. Potrebovali smo poklicni kader za vodenje enot, popolnjenih z obvezno rezervo, in za usposabljanje nabornikov. Stalna sestava Slovenske vojske se je povečala na račun novozaposlenih poveljnikov oddelkov (podčastniki), vodov, čet, učnih centrov in bataljonov (častniki) za izvajanje usposabljanja ter podčastnikov in častnikov poveljstev vseh ravni.

$\mathrm{V}$ času, ko smo zaznavali in čutili ogroženost miru in stabilnosti predvsem v ostankih nekdanje Jugoslavije, smo razvijali vojaško organizacijo, ki je z izkušnjami in vojno dokazala, da se proti taki nevarnosti zna boriti. S pomočjo Zakona o zagotavljanju sredstev za realizacijo temeljnih razvojnih programov obrambnih sil RS v letih 1994-2003 (Uradni list RS, št. 13/94) in financiranjem iz rednega proračuna smo poskušali opremiti, organizirati in usposobiti vojsko, sposobno samostojne obrambe naše suverenosti in nedotakljivosti. Teritorialno obrambo in od leta 1994 Slovensko vojsko sta odlikovali predvsem množičnost in uravnotežena razvitost (organizacijsko-mobilizacijski razvoj) v vseh delih naše države. Infrastrukturo, namenjeno naborniški vojski in prilagojeno takšnemu organizacijsko-mobilizacijskemu razvoju, nam je zapustila že jugoslovanska vojska, veliko objektov te infrastrukture (kadetnica v Mariboru, vojašnica v Bohinjski Beli, letališče v Cerkljah) pa je bilo tudi že pred drugo svetovno vojno. Vojaško organizacijo kot nosilca vojaške obrambe smo vzpostavili skupaj s civilno obrambo in prilagodili naborniškem sistemu. S služenjem vojaškega roka smo skoraj vso moško populacijo države usposabljali za opravljanje različnih vojaških nalog v vojni. Še danes je več kot deset odstotkov prebivalstva usposobljenih (se je usposabljalo) za različne oblike vojaške obrambe na domačem ozemlju. Stalna in rezervna sestava TO in pozneje Slovenske vojske sta številčno rasli, od 369 zaposlenih v Republiškem sekretariatu za ljudsko obrambo konec junija 1991 je stalna sestava narasla na približno 4000 pripadnikov. Vodilni del vojske so predstavljali predvsem častniki, usposobljeni na šolah za rezervne oficirje $\mathrm{v}$ 
jugoslovanski vojski, ki so se pozneje kalili v osamosvojitveni vojni. Z začetkom sodelovanja $\mathrm{v}$ mirovnih operacijah so se pojavili novi izzivi in nova vprašanja, na katera smo morali poiskati ustrezne odgovore. Sodelovanje letalsko-helikopterskega oddelka v mirovni misiji ni predstavljalo večje težave, ta enota svojo nalogo v mirovni operaciji brez nesreč opravlja že več kot šest let. Težava pa se je pojavila z naslednjimi operacijami, saj nismo imeli primerne enote ali usposobljenega zadostnega števila vojakov ali posameznikov, ki bi jih lahko oblikovali kot enoto in poslali na vojaško (mirovno) operacijo v tujino. Posameznike za misije in operacije smo zbirali v vsej Slovenski vojski. Še težje je bilo za vojaške vaje zbrati ustrezno opremo in sredstva iz popisa; svojih nismo imeli dovolj, gospodarstvu pa jih je bilo iz upravičenih razlogov še težje jemati. V slovenskem prostoru nikoli ni bilo težko dobiti sredstev za obrambo domovine, za »pravo stvar«, v miru pa je za usposabljanje iz razumljivih vzrokov (pridobitna dejavnost lastnikov) to postajalo vse težje. Zaradi rastočih zahtev v mednarodnem sodelovanju je nastal bataljon (sedaj 10.) za mednarodno vojaško (mirovno) sodelovanje, ki naj bi bil popolnjen samo s poklicno sestavo. Na upočasnjeno popolnjevanje, opremljanje in razvoj tega bataljona je verjetno vplivalo tudi to, da Slovenija v Nato ni bila povabljena v prvem krogu širitve. Pomembno pa je, da smo začeli spoznavati, da potrebujemo enote, popolnjene s poklicno sestavo.

\section{POLNOPRAVNO ČLANSTVO V NATU IN EU}

Po prvem krogu širitve Nata, ko je tudi Madžarska postala polnopravna članica, po vse boljših vojaških odnosih z Republiko Avstrijo in Republiko Italijo ter po spremembi razmer jugovzhodno od Slovenije je postal varnostni položaj Republike Slovenije bistveno ugodnejši. Politični režimi v regiji so se spreminjali, jugoslovanski predsednik Milošević je po vojaškem porazu leta 1999 izgubil svojo vojaško moč. Vojaško sodelovanje Slovenske vojske kot nadaljevanje zelo dobrih gospodarskih in političnih odnosov s sosedi, drugimi evropskimi državami in ZDA se je poglobilo. Analize slovenskega javnega mnenja kažejo, da se je občutek varnosti državljanov in državljank povečal (poročilo raziskovalnega projekta Stališče slovenske mladine do vojaškega poklica 2003, primerjava rezultatov iz let 1990, 1991, 1994 in 1995, Fakulteta za družbene vede, Obramboslovni raziskovalni center, Ljubljana, september 2003). Vojaška moč Slovenske vojske se je krepila, vojska je v tem času intenzivno uvajala standarde posameznih evropskih vojsk, povezljivost je postajala vse pomembnejša. Vse pogostejše skupne vaje in usposabljanja z državami članicami Partnerstva za mir in severnoatlantskega zavezništva so dokaz, da se zmoremo bojevati z ramo ob rami s temi vojskami.

$\mathrm{V}$ tem času se je postopoma večalo tudi število naših pripadnikov v mirovnih operacijah ter število vojaških predstavnikov v tujini. Izrazito se je večalo tudi število častnikov in podčastnikov, ki so pridobivali novo vojaško znanje v tujini, na skupnih usposabljanjih in vajah ter na najvišjih vojaških šolah. Izkušnje in obseg ter kvaliteta našega znanja so se postopoma širili. Novembra 2002 smo dobili vabilo za članstvo v Natu. Na referendumu smo se z dvotretjinsko večino odločili 
zanj. Tako smo dodatno okrepili in utrdili svoj obrambno-varnostni položaj, hkrati pa se tudi zavezali, da bomo obrambne zadeve reševali skupaj in v korist vsega severnoatlantskega zavezništva. Odnos je korekten - mi pomagamo zavezništvu, oni pomagajo nam; oblika in količina pomoči pa sta stvar pogajanj. Tudi mi smo postali zavezništvo.

\section{ZNAČILNOSTI PRIHODNJIH VOJAŠKIH OPERACIJ}

Vojne v nekdanji Jugoslaviji in v svetu (Kosovo leta 1999, Afganistan, letos Irak, liberijski dogodki) nam nakazujejo smer in razvoj svetovnih dogodkov ter smer in značaj prihodnjih vojaških operacij. Možnost vojaškega spopada doma ali v bližnji okolici seveda ostaja, verjetnost, da do njega dejansko pride, pa je zelo majhna. Razvoj globalizacije in vse močnejše težnje po razvoju skupnih regionalnih večnacionalnih vojaških enot nas vodijo v sklep, da bomo vojaške naloge opravljali večinoma zunaj Slovenije, skupaj z našimi zavezniki in prijatelji. Vse izrazitejše je stališče, da je treba vojaške spopade, napetosti in ogrožanja preprečevati oziroma jih pomagati reševati še preden se razvijejo v resen meddržavni, medetnični ali kakšen drug konflikt in preden dosežejo meje lastne države ter ogrozijo njeno varnost, stabilnost, socialni mir in gospodarski razvoj. Cena, izražena s številom mrtvih, ranjenih in poškodovanih, cena gospodarske obnove in obnove infrastrukture je neprimerljivo manjša, kot je soočenje z virom ali posledico ogrožanja na meji. Sodobne oborožene sile so izrazito dobro opremljene, organizirane, usposobljene ter predvsem logistično samostojne (po načelih premičnosti, premestljivosti, vzdržljivosti, zaščite sil, povezljivosti in združljivosti) in zahtevajo dobro podporo bojnega delovanja ter bojno podporo (Combat Support, Combat Service Support). Sestavljajo jih zavezniške enote (trajnejša organizacija) ali enote koalicije za opravljanje enkratne vojaške naloge. Države, z izjemo velikih, razvijajo le posamezne komponente ali specialnosti oboroženih sil. V Evropi (tudi z Nato Reaction Force) so težnje razvoja in združevanja sil zelo izrazite, imajo svojo tradicijo. Po nastanku Nata se je na primer najprej združila zračna obramba držav članic, sledile so posamezne mornariške povezave in združitve (Nizozemska, Belgija), sedaj se združujejo tudi večje kopenske enote.

Sodobna vojaška oprema, zahtevana visoka izurjenost in usposobljenost posameznika in enote ter hiter tempo vseh vrst sodobnih vojaških operacij zahtevajo daljše usposabljanje vojakov, podčastnikov in častnikov ter enot. Nabornika je med kratkim služenjem vojaškega roka (v Sloveniji sedem mesecev) za takšno bojevanje nemogoče usposobiti. Neusposobljen vojak na bojišču ogroža samega sebe, svoje tovariše, enoto in je lahek plen za nasprotnika. V mornarici in letalstvu so se s podobnimi težavami (zahtevnost opreme in usposabljanja, visoka usklajenost delovanja) srečali že pred desetletji, zato je dele teh vojaških zvrsti profesionalizacija zajela že veliko prej; sodobna kopenska oprema pa te korake narekuje tudi za kopensko vojsko. Kopenska vojska (Land Force) je v večini držav najštevilčnejša, zato je proces profesionalizacije teh delov vojske tudi najbolj boleč (izkušnja španskih oboroženih sil; Major General Felix Lanz Roldan, 
junij 2003). Cilj sodobnega, dobro opremljenega in izurjenega vojaka je opraviti nalogo ter preživeti na bojišču, sam in s tovariši. Slabo opremljen, neizurjen vojak in neusposobljena enota imata zelo malo možnosti za preživetje; slabo ali pomanjkljivo usposabljanje različnih enot znotraj ene vojske ali višje enote in pomanjkanje usposabljanja zavezniških ali koalicijskih enot pa zmanjšujeta učinke bojevanja in povečujeta možnosti napak in odpiranja prijateljskega ognja (znani primeri iz Afganistana: ameriška letala so delovala po Kanadčanih, v Iraku zabeleženo še več primerov).

V Slovenski vojski smo spremljali razvoj in predvidevali takšno vrsto sodobnega bojišča. Jasno nam je, da moramo organizirati, opremiti in usposobiti vojsko za izvajanje nalog doma in $\mathrm{v}$ tujini, samostojno ter $\mathrm{v}$ sodelovanju $\mathrm{z}$ zavezniki in prijatelji. Da bi to dosegli, smo sodelovali pri pripravi strateškega pregleda obrambe, pripravili smo osnutek splošnega dolgoročnega plana razvoja in opremljanja SV. Namen, cilj (tudi) vojaške obrambe je »odvračanje napada na državo ter obramba neodvisnosti, nedotakljivosti in celovitosti države ... tudi z vključevanjem in $\mathrm{z}$ aktivnim sodelovanjem v mednarodnih varnostnih povezavah« (2. člen Zakona o obrambi). Z majhno, moderno opremljeno, odlično usposobljeno in učinkovito vojsko ter s kolektivno obrambo bomo dosegli zastavljeni cilj. S profesionalizacijo SV, približevanjem zavezniškim strukturam, vključitvijo vanje ter preoblikovanjem gradimo vojsko, sposobno odgovoriti novim varnostnim izzivom prihodnosti.

\section{STANJE V SLOVENSKI VOJSKI}

Leto 2002 smo dočakali s 76000 pripadniki vojne sestave, organiziranimi predvsem znotraj treh operativnih poveljstev ter Prve brigade Slovenske vojske. S Konceptom SV 2004 in Obrambno strategijo RS (Vlada RS, št. 820-00/2001, december 2001) smo načrtovali postavitev enega samega operativnega poveljstva in številčno zmanjšanje vojne sestave. Verjetnost vojaškega ogrožanja države je bila v tem letu bistveno manjša kot pred desetimi leti, rast bruto domačega proizvoda je bila na visoki ravni, nad tremi odstotki, s programom partnerstva za mir ter z dvo- in večstranskim sodelovanjem s tujimi vojskami pa smo postajali vse bolj povezljivi z drugimi državami. Imeli smo svoje partnerske cilje (Partnership goals), ki so nam omogočali prva vedenja o tem, kako moramo biti opremljeni ter usposobljeni za skupne mirovne in druge zavezniške operacije. Pričakovali smo drugi krog širitve Nata in bili prepričani, da bomo vanj tudi povabljeni. Za sodelovanje v mirovni operaciji v Albaniji (1997) smo prvič uporabili neke vrste pogodbeno rezervo, ki je zelo dobro opravila svojo nalogo. V BiH smo leta 2002 v okviru SFOR-ja sodelovali z vodom vojaške policije (vod smo oblikovali z zbiranjem vojaških policistov, ki so se odločali prostovoljno) ter z medicinsko enoto (ROLE), sestavljeno iz vojaškega medicinskega osebja in osebja po pogodbi. Posamezniki so bili vključeni tudi v druge mirovne misije. 15. BRVL je nadaljevala svojo nalogo v SFOR-ju. Kljub velikemu številu pripadnikov še vedno nismo imeli enote, ki bi se lahko kot celota vključevala v tovrstne dejavnosti. 
Z Italijani in Madžari smo v tem letu že imeli sporazum o oblikovanju skupne enote v velikosti brigade (t. i. MLF, Multinational Land Force), ki bi opravljala naloge pod okriljem Združenih narodov ali Nata. Naš prispevek tej enoti znaša en bataljon; skupne vaje in usposabljanje te enote pa so redna dejavnost treh vojsk.

Usposabljanje številčno velike vojne sestave je bilo posebno poglavje. Z vojaškim proračunom, ki je bil celo blizu enega odstotka BDP, in z vse večjim obsegom operacij v tujini je bilo vse teže usposabljati rezervno sestavo na način, ki bi omogočal visoko pripravljenost za bojevanje. Srečali smo se s pomanjkanjem sredstev, z vse manjšim odzivom na usposabljanjein z zavestjo, da ogroženost države ni tako velika, da bi celotna vojna sestava morala biti enako pripravljena za bojevanje.

Varovanju objektov smo še posebej po kraji orožja v Postojni posvečali veliko pozornost, tako organizacijsko kot tehnično. Začeli smo ga izvajati tudi s stalno sestavo Slovenske vojske, klasično stražarsko službo pa so še naprej opravljali vojaki naborniki. Do 500 vojakov nabornikov ter podčastnikov in častnikov je bilo hkrati angažiranih pri varovanju.

Usposabljanje vojakov nabornikov je potekalo na 18 lokacijah po vsej Sloveniji. Izvajali smo štiri letne vpoklice. Velikosti kontingentov so bile take, da smo v tretji fazi usposabljanja popolnjevali logistične enote vojašnic in nekatere bojne enote ter seveda gardni bataljon oziroma našo protokolarno enoto. V tem letu je že več kot polovica vojakov opravljala pomožne dejavnosti v Slovenski vojski, drugi del pa je izvajal naloge pripravljenih ter intervencijskih sil. Zaradi takega načina dela je bila večina stalne sestave angažirana pri usposabljanju vojakov nabornikov. Tipičen bataljon Slovenske vojske je štel od 60 do 100 pripadnikov stalne sestave, večinoma podčastnikov in častnikov, redko tudi poklicnih vojakov.

Ugotovimo lahko, da se je del stalne sestave ukvarjal z vojaki naborniki, drugi del pa je dejansko izvajal že tretje preoblikovanje Slovenske vojske. S tem preoblikovanjem smo delno, vendar neznatno zmanjšali vojno sestavo, prepodredili posamezne enote in poveljstva, prerazporedili del kadrov, bistvenih izboljšav, predvsem na področju usposobljenosti celotne sestave, pa nismo dosegli. Oblikovali smo tri operativna poveljstva (vzhod in zahod, drugo in tretje, z osnovno nalogo usposabljanja stalne sestave, vojakov nabornikov in rezervne sestave, ter prvo, namenjeno nadzoru zračnega prostora, zračni obrambi in letalstvu, predvsem helikopterskim nalogam) ter prvo brigado, ki je bila namenjena vodenju vseh mednarodnih operacij in misij v tujini. Možnosti pri sprejemanju posameznih standardov oziroma partnerskih ciljev, katerih del so določeni standardi, so bile tako zelo majhne. Resnično težko se je hkrati ukvarjati z usposabljanjem nabornikov, z varovanjem in vzdrževanjem infrastrukture, $\mathrm{z}$ usposabljanjem obvezne rezerve ter $\mathrm{z}$ izvajanjem posameznih nalog po določenih, za nas novih standardih opremljanja in delovanja ter z njihovo vgradnjo $\mathrm{v}$ redno delo. Vse naloge ne morejo biti opravljene $\mathrm{z}$ enako prioriteto in enako kakovostno, posledice so bile opazne. Spoznavali smo, da bomo morali 
postaviti drugačno vojsko na drugačni podlagi, ki ji bomo lahko omogočili pogoje za dobro delo in s katero bomo postali učinkovitejši in sposobnejši.

Dopolnila in spremembe zakona o obrambi (Uradni list RS, št. 47/02 in 67/02) ter Dopolnila in spremembe zakona o vojaški dolžnosti (Uradni list RS, št. 86/02) so omogočila začetek profesionalizacije. Te spremembe so nastale kot posledica presoje varnostnih razmer, analize stanja Slovenske vojske (in obrambnega sistema) ter izkušenj iz mednarodnih operacij in mirovnih misij v letih 2000, 2001 in v začetku 2002. Ena od ključnih zadev navedenih sprememb in dopolnil je zakonska obveza, da s služenjem v obvezni rezervi Slovenske vojske prenehamo do leta 2010 in da zadnjo napotitev na služenje vojaškega roka opravimo najpozneje do 30. junija 2004. Druga dva ključna dokumenta je sprejela Vlada RS (Sklep o spremembah in dopolnitvah sistema popolnjevanja SV in Sklep o projekciji obrambnih izdatkov za obdobje 2002 do 2010; april, maj in junij 2002). Nanašala sta se na popolnitev SV oziroma zaposlovanje. S temi sklepi nam je vlada omogočila zaposlovanje novih poklicnih vojakov in pogodbenih rezervistov. Neposredna posledica teh sklepov (novo zaposlovanje in intenzivno usposabljanje) je bilo povečanje vojaškega kontingenta $\mathrm{v}$ $\mathrm{BiH}$ v začetku letošnjega leta, in sicer za motorizirano četo. Motorizirana četa je bila opremljena, usposobljena in preverjena po Natovi metodologiji.

Sprejeta dopolnila in spremembe obeh zakonov so zahtevali takojšnjo temeljito analizo stanja ter podrobno načrtovanje naslednjih možnih korakov in različic dogodkov ter scenarijev razvoja situacije. Analize so pokazale, da moramo pospešeno in prednostno razvijati določene vojaške enote, popolnjene predvsem s poklicnimi pripadniki, ter da moramo enako prednostno in pospešeno urejati področje, povezano z varovanjem opreme, oborožitve in objektov. Ugotavljali smo, da popolnjenost enot z obvezno rezervo, poklicnimi vojaki in naborniki na usposabljanju ne more dati zadovoljivih rezultatov. Morali smo izoblikovati pogoje, pod katerimi bo opustitev vpoklica vojakov nabornikov tudi zakonsko uresničljiva oziroma da bodo vpoklici načrtovani na način, ki v trenutku sprejemanja odločitve o opustitvi služenja vojaškega roka ne bo povzročil razlik in morebitnih krivic med posameznimi generacijami in naborniki ene generacije oziroma enega vpoklica. Pri posameznem vpoklicu smo začeli načrtno zmanjševati število vpoklicanih, julijski vpoklic nabornikov 2003 pa smo preskočili.

\section{DOSEGANJE IN IZPOLNJEVANJE POGOJEV ZA OPUSTITEV SLUŽENJA VOJAŠKEGA ROKA}

Generalštab je septembra letos ponovno analiziral stanje in naloge Slovenske vojske v letih do 2010, ko preneha zakonska obveza popolnjevanja vojne sestave z obvezno rezervo, pogoje za delovanje in izpolnjevanje z Zakonom o obrambi določenih nalog v sedanjem in prihodnjem obdobju, pogoje za delovanje Slovenske vojske v prihodnjem srednjeročnem obdobju, analiziral je spremembe v varnostnem okolju. Dodaten element analize je bilo doseganje ciljev ponudbe sil zavezništva, ki je nastala kot rezultat naših dogovorov in pogajanj z zavezništvom. Ugotovili smo, da 
nadaljnje služenje vojaškega roka v miru ni več potrebno ter da so izpolnjeni pogoji za prenehanje tega služenja. Samostojno ali skupaj z upravnim delom Ministrstva za obrambo smo v tem času izvedli naslednje ukrepe za omogočanje prehoda na poklicno vojsko, dopolnjeno s pogodbeno rezervo:

- pripravili smo spremembe normativnih podlag (Zakon o obrambi, podzakonski predpisi ...);

- zmanjšali smo število enot, predvsem poveljstev (npr. ukinili smo tri, načrtujemo ukinjanje še dveh brigadnih poveljstev);

- zmanjšali smo število objektov in opravili koncentracijo sil in sredstev $\mathrm{v}$ perspektivne objekte, ki jih tehnično opremljamo (smo pri koncu programa);

- pripravili smo nov koncept usposabljanja in izobraževanja, prilagojen profesionalni vojski. Vzpostavljamo organizacijo SV po sprejetem konceptu usposabljanja (oblikovali smo Center za usposabljanje Vipava). Sprejeli smo organizacijske ukrepe za usposabljanje prostovoljne - pogodbene rezerve v gorskem bataljonu;

- v enotah, kjer se je postopoma zmanjševalo število nabornikov, izvajamo usposabljanje poklicne sestave za prevzemanje nalog v prihodnji poklicni strukturi (splošno in specialistično vojaško usposabljanje);

- posebej smo obravnavali varovanje objektov: zmanjševanje števila objektov, tehnično opremljanje, spremembe načina skladiščenja.

Dodatni elementi, ki so vplivali na odločitev za predčasno opustitev služenja vojaškega roka, so:

- z bližanjem zakonskega roka, ko bo treba opustiti obvezno služenje vojaškega roka, je bilo vedno težje zagotavljati dovolj nabornikov, načrtovano število smo sicer še lahko zagotovili;

- vojaški obvezniki, ki so prihajali na služenje vojaškega roka, so bili vse manj motivirani za služenje, število vlog za uveljavljanje ugovora vesti je počasi naraščalo;

- enote SV so se prilagajale stanju, ko ne bo več vojakov na služenju. Nadaljnja razporeditev vojakov nabornikov v enote SV bi zanje predstavljala dodatno breme in tako bojna pripravljenost SV ne bi rasla.

Analizirali smo zahteve za oblikovanje intervencijskih sil za posredovanje na objektih SV in MO RS ter v nalogah zaščite in reševanja. Podrobneje smo proučili naloge dodatne zaščite, varovanja in obrambe objektov SV in MO RS, zaščite in varovanja poveljstev in oseb, premikov na ozemlju RS ter mobilizacije. Ugotovili smo, da z ustrezno organizacijo sistemov dežurstev ter izvedbo nalog izpolnimo postavljena merila za opravljanje teh nalog. V dosedanjem popolnjevanju SV kot dela procesa profesionalizacije oziroma projekta PROVOJ smo zaposlili preko 1600 poklicnih vojakov in več kot 250 kandidatov za vojake, skupna sestava SV pa je narasla na več kot 6300 pripadnikov. Usposobljenost poklicnih vojakov in njihova opremljenost z opremo Bojevnika 21. stoletja sta bistveno boljši, trenutna učinkovitost v primerjavi z naborniško vojsko ni primerljiva. S promocijskimi dejavnostmi zagotavljamo dovolj kandidatov za poklicne vojake in podčastnike. Z navedenim številom zaposlenih, $\mathrm{s}$ približno 400 pripadniki pogodbene rezerve ter $\mathrm{z}$ obvezno rezervo, opredeljeno $\mathrm{z}$ zakonom, smo sposobni opraviti naše sedanje naloge. 
Vojaki na služenju vojaškega roka so v mobilizacijskem sistemu predstavljali vir za dopolnjevanje VE in opravljali manjše pomožne naloge. Zaradi ugodnih ocen varnostne situacije opustitev obveznega služenja vojaškega roka ne pomeni zmanjšanja mobilizacijske pripravljenosti vojske. Ponovno opredeljujemo mobilizacijo vojske in pripravljamo novo navodilo za izvajanje. Mobilizacijo kot pojem povezujemo s pripravljenostjo enote za izvajanje dodeljene naloge in ne več zgolj z oblikovanjem enote.

V mobilizacijskem sistemu načrtujemo spremembe mobilizacijskih časov-podaljšanje na 30, 90 in 180 dni. Tako se približujemo standardom in merilom v zavezništvu. Te spremembe ne pomenijo, da bo mobilizacija lažja, ampak bo celo zahtevnejša. Načrtujemo manjše število subjektov - enot, enote bodo imele drug namen in drugačne naloge, načrtujemo tudi logistične spremembe v sistemu mobilizacije.

\section{Varovanje objektov}

Z zmanjševanjem števila skladišč orožja, streliva in MES sta se občutljivost in pomen posameznih skladišč povečala. Zato smo uvedli tehnično varovanje in varovanje s stalno sestavo. To nalogo je opustitev naborniškega sistema najbolj prizadela oziroma je bila na tem področju sprememba po opustitvi služenja najbolj očitna.

Potrebno število moštva za varovanje smo z organizacijskimi in tehničnimi ukrepi zmanjšali. Na večini objektov je tehnično varovanje že ustrezno vzpostavljeno, da ni treba vsake točke in objekta vedno nadzorovati z ljudmi. V letošnjem letu opremljamo s sistemom tehničnega varovanja tudi nekaj dodatnih skladišč. Varovanje je osredotočeno na kritične točke in ne več na pokrivanje prostora, varovanje vojašnic izvajamo s tehničnim varovanjem posameznih zgradb in fizičnim varovanjem varnostno nadzorno službo, varovanje skladišč pa s celovitim tehničnim varovanjem, operaterji in patruljami v objektih. Strelišča, vadišča in izpraznjene neperspektivne objekte bomo varovali z občasnimi obhodi.

S temi ukrepi smo moštvo za varovanje objektov zmanjšali na največ 100 (zaradi različnih zahtev patruljiranja) pripadnikov poklicne sestave $\mathrm{v}$ eni izmeni oziroma 440-500 pripadnikov vojske za zagotovitev izmenskega dela. Še naprej zmanjšujemo število objektov, ki so potrebni varovanja, kar je način za nadaljnje zmanjševanje teh sil, in nadaljujemo uvajanje celovitega tehničnega varovanja vseh skladišč in ogroženih objektov v vojašnicah, s čimer bomo izboljšali predvsem kvaliteto varovanja. Uporabljali bomo tiste rešitve, ki bodo zagotavljale potrebno varnost ljudi in premoženja ter ne bodo preveč obremenjevale pripadnikov Slovenske vojske.

\section{Usposabljanje}

Usposabljanje vojakov na služenju vojaškega roka je potekalo na 18 lokacijah po Sloveniji: v Ljubljani (Vojašnica Franca Rozmana Staneta in Vojašnica Šentvid), na Vrhniki (Vojašnica 26. oktober in Vojašnica Ivana Cankarja), v Kranju, Bohinjski 
Beli, Postojni, Vipavi, Ilirski Bistrici, Novem mestu, Cerkljah ob Krki, v Celju, Mariboru, Ptuju, Slovenski Bistrici, Murski Soboti, Pivki, Ankaranu, občasno pa tudi v drugih objektih.

Temeljno usposabljanje je $\mathrm{v}$ zadnjih dveh letih potekalo na štirih lokacijah. To so Maribor, Ptuj, Novo mesto, Bohinjska Bela, specialistično usposabljanje pa v centru in enotah SV na devetih lokacijah: Cerklje ob Krki, Maribor, Slovenska Bistrica, Vipava, Pivka, Ljubljana (FRS), Ankaran, Kranj, Vrhnika. Temeljno (TVSU) in osnovno (OVSU) vojaškostrokovno usposabljanje potekata v Centru za usposabljanje (CU) Vipava in Centru vojaških šol (CVŠ). Enote, popolnjene s profesionalno sestavo (1. BR), izvajajo usposabljanje skladno z vsebinami iz že narejenih načrtov in programov za usposabljanje vojakov (predvsem urjenje enot), $v$ enotah, ki so do sedaj izvajale usposabljanje vojakov na služenju vojaškega roka, pa potekata specialistično in splošno usposabljanje.

Usposabljanje vojakov na prostovoljnem služenju vojaškega roka bo potekalo v štirih vojašnicah (Bohinjska Bela, Novo mesto, Murska Sobota, Postojna), nanj je SV organizacijsko in kadrovsko že pripravljena. Zagotovili smo 1150 ležišč v osmih vojašnicah, z možnostjo povečanja še v dveh. V letu 2003 se usposablja pogodbena rezerva v 1. GORČ, v prihodnjem letu pa načrtujemo usposabljanje pogodbene rezerve $\mathrm{v}$ 9. RBR ZO, 18. BRBKO in v 132. GORB oziroma v petih vojašnicah (Bohinjska Bela, Novo mesto, Postojna, Maribor, Vrhnika).

Z opustitvijo obveznega služenja vojaškega roka ustvarjamo pogoje za zmanjšanje števila objektov za usposabljanje, enotam pa omogočamo, da je kvalitetnejše (splošno in specialistično), kar do sedaj v večini primerov ni bilo mogoče, saj so se usposabljanja ponavljala $\mathrm{z}$ novimi naborniki (usposabljanje nabornikov smo zaključili s tretjo fazo in se znova vračali $\mathrm{v}$ prvo fazo). Z uvajanjem kategorije poklicnih vojakov izpolnjujemo tudi pogoje za opremljanje vojske z zahtevnejšo vojaško opremo in oborožitvijo iz temeljnih razvojnih programov.

Z ukinitvijo naborniškega sistema v SV in prehodom na poklicno vojsko spreminjamo organizacijo dežurnih služb. Organizacija bo zaradi neprekinjene pripravljenosti sistema vodenja in poveljevanja temeljila na operativnem dežurstvu in dežurstvu $\mathrm{v}$ vojašnicah, vanj bodo vključeni elementi nadzora dela in izpolnjevanja nalog (vključno z zavarovanjem) vseh enot v vojašnici. S tem načinom smo zmanjšali število dežurnih služb in razbremenili pripadnike stalne sestave prevelikega števila nalog.

\section{Infrastruktura}

SV je od večjih objektov upravnemu delu MO RS za nadaljnji postopek že predala vojašnici v Logatcu in Ilirski Bistrici ter nekatere manjše objekte in skladišča: vadišče Kostanjevica na Krasu, vojašnico v Velikih Blokah, objekt Jedinščica v Novem mestu, skladišče Talčji Vrh pri Črnomlju ter skladišča Sevnica, Dovjež, Borovec v Kočevski Reki in Slovenske Konjice. Izpraznjena sta tudi objekta Lokve in Moretini, načrtujemo še izpraznitev in predajo dveh vojašnic. Bistvena ugotovitev 
te analize je, da z nadaljevanjem služenja vojaškega roka do sredine leta 2004 ne povečujemo obrambnih sposobnosti države in kvalitete opravljenih vojaških nalog. Z opustitvijo napotitve na služenje vojaškega roka pred predvidenim rokom (natančneje - v roku, saj je zakonska dikcija jasna: do 30. junija 2004) pa pridobimo predvsem čas za temeljito prestrukturiranje vojske, uvajanje novih standardov in pripravo za uresničevanje namenskih nalog.

\section{PREDLOG MINISTRU ZA OBRAMBO O OPUSTITVI VPOKLICA OKTOBRSKE GENERACIJE VOJAKOV}

Pri razumevanju navedene problematike je treba ponovno opozoriti na že znano dejstvo in trditev, da je vojska orodje v rokah politikov in da je v vsaki demokratični družbi vojska pod civilnim nadzorom. Generalštab kot najvišji organ vodenja in poveljevanja je seveda stalno analiziral razmere in stanje v Slovenski vojski, presojal razvoj varnostne situacije in mednarodnih dogodkov ter predlagal različne rešitve. Niti Generalštab niti Slovenska vojska kot celota pa nista popolnoma samostojni instituciji, ki bi lahko delovali mimo našega sistema državne ureditve ter predlagali in dobili prav vse, kar bi po svoji presoji potrebovali. Take razmere in tako razmerje moči smo v naši zgodovini že poznali, poznamo tudi primere v svetu, ki za nas nikakor ne morejo biti sprejemljivi. Naše zahteve in predlogi so seveda deležni pozornosti in upoštevanja, še zdaleč pa ni nujno, da so v sistemu demokratične ureditve sprejeti v predlagani obliki.

Zato smo predloge za postopno opustitev služenja vojaškega roka poslali $\mathrm{v}$ parlamentarno obravnavo. Po sprejemu sprememb in dopolnil Zakona o obrambi in Zakona o vojaški dolžnosti je bilo treba ponovno analizirati naloge vojske, časovne roke in vire za uresničitev teh nalog ter poiskati $\mathrm{v}$ teh razmerah ustrezno različico optimalnih pogojev za nadaljnji razvoj. Kot pogoj za opustitev napotitve na služenje vojaškega roka smo morali izpolniti nekatera kadrovska in organizacijska merila, tako da sem lahko predlagal ministru za obrambo opustitev vpoklica oktobrske generacije vojakov nabornikov. Menim, da so $\mathrm{v}$ danem trenutku varnostne razmere, sedanje in prihodnje naloge Slovenske vojske ter predvideni čas za usposobitev novih enot narekovali to odločitev in da sta trenutek in način ustrezala sprejetju te odločitve.

\section{PREDNOSTNE NALOGE RAZVOJA SV}

Varnostno okolje in predvsem načini, kako bomo v bližnji in daljni prihodnosti uresničevali z zakonom o obrambi določene naloge, se hitro spreminjajo. Skupaj z upravnim delom Ministrstva za obrambo smo pripravili strateški pregled obrambe in osnutek splošnega dolgoročnega programa razvoja in opremljanja SV do leta 2015 ter jih med nastajanjem tudi usklajevali z drugimi dokumenti in z našimi zavezniki. Prihodnost v okviru zavezništva presojamo kot zanesljivo in stabilno, smer našega razvoja pa kot jasno določeno in zapisano. Gremo v zavezništvo, postajamo njegov del in gradimo profesionalno vojsko. 
Morebitne spremembe varnostnega okolja bodo seveda zahtevale ponovno presojo situacije in ponovno prilagajanje in odzivanje na varnostne izzive in morebitne nove grožnje naši suverenosti in nedotakljivosti ter miru in stabilnosti. Majhna in sodobna vojska se bo takšnim spremembam in novim zahtevam zlahka prilagajala. Izkušnje nas učijo, da to delo ni nikoli končano. Nadaljevanje procesa profesionalizacije vse do konca tega desetletja, približevanje zavezniškim strukturam in vključevanje vanje ter gradnja strukture, ki bo ustrezala zahtevam časa in nalog vojaške obrambe, so tri temeljne sestavine obrambnih reform.

Področij dela, na katerih bi lahko izboljšali stanje, je veliko. Kritična presoja lastnega dela nam bo odgovorila na vprašanje, kje in kaj bi lahko bolje naredili. Opravimo to profesionalno. Dokler zaznavamo odstopanja, smo kritični in se razvijamo v pravi smeri, ne smemo pa prezreti, da smo veliko dobrih stvari že napravili.

Sklep Razlika med nami in nam primerljivimi državami je več kot očitna. Druge države so že imele svojo vojsko, ki jo je bilo treba zmanjšati, preoblikovati in modernizirati (Madžarska, Avstrija, Češka). V zadnjem desetletju je večina vojsk doživljala spremembe, ki so bile naravnane predvsem na nove oblike ogrožanja in nove varnostne izzive v okolju. Mi smo začeli Slovensko vojsko in njene posamezne elemente leta 1991 šele graditi na temeljih in tradiciji, ki jih je postavila teritorialna obramba za varnostne izzive zadnjega desetletja prejšnjega stoletja. Zelo splošno rečeno, drugi morajo odpuščati, mi pa številčno stanje poklicne sestave povečujemo. Prehod drugih, številčnejših vojsk na druge načine popolnjevanja je počasnejši iz povsem preprostega razloga, ker je v kratkem času nemogoče zamenjati naborniški kontingent trideset ali štirideset tisoč vojakov s pogodbenimi ali poklicnimi vojaki. Opustitev služenja vojaškega roka je samo eden od korakov profesionalizacije Slovenske vojske. Nadaljevali bomo popolnjevanje s poklicnimi vojaki in pogodbeno rezervo. V projektu PROVOJ smo zapisali, da bo proces profesionalizacije trajal do leta 2010. Do takrat bomo poklicno opravljali svoje naloge, se modernizirali, kvalitetnejše usposabljali in postajali učinkovitejši. Posamezniki že sedaj odlično in profesionalno opravljajo svojo dolžnost, nekatere enote bodo v tem procesu hitreje dosegle profesionalnost. Naš cilj pa je posameznikom, pripadnicam in pripadnikom vojske, enotam in poveljstvom z opremljanjem, organiziranjem, pogoji dela in bivanja ter visokimi standardi usposabljanja omogočiti postopen prehod od povprečnosti do popolne profesionalnosti.

Danes potrebujemo novo vojsko za novo tisočletje. Z jasno referendumsko odločitvijo o našem članstvu v Evropski uniji in severnoatlantskem zavezništvu smo si izbrali pot skupne, kolektivne obrambe, za katero pa koncept splošnega ljudskega odpora in družbene samozaščite v največjem delu ni primeren. »Pogajanja« z zavezništvom še trajajo, vendar je že sedaj skoraj popolnoma jasno, katere dele vojske bomo sami razvijali, kakšen bo naš prispevek k zavezništvu in kaj lahko mi pričakujemo od skupne obrambe. 
Smo relativno majhna država z razmeroma majhno vojsko. Znana je misel, da dober poveljnik svoje slabosti spremeni v prednosti; naša relativna majhnost nam seveda ponuja večje možnosti hitrejšega odgovora in hitrejšega prilagajanja novim varnostnim izzivom, takšno prednost je seveda treba temeljito izkoristiti. Uspešno smo se znali organizirati za nalogo osamosvajanja, uspešno smo odgovorili izzivom zadnjega desetletja minulega stoletja in znali se bomo organizirati, opremiti in usposobiti za prihodnje izzive. Ne gre dvomiti o naših odločitvah in uspešnosti profesionalizacije, približevanju in integraciji ter preoblikovanju Slovenske vojske, te naloge bomo zanesljivo opravili. Velja se potruditi, da jih opravimo kot poklicni vojaki, podčastniki in častniki ter kot profesionalci na vojaškem področju, z odliko. Merilo naše uspešnosti bodo vojaške zmage in ugled, pridobljen z odlično opravljeno nalogo.

Ob vsem pa velja dodati, da naborniškega sistema ne smemo pozabiti, ne samo zaradi zakonskega določila, ki ob morebitni izjemni ogroženosti omogoča ponovno uvedbo tega sistema, temveč zaradi spoznanja, da nam je omogočil osamosvojitev. Večina se nas je srečala z naborništvom in ima takšne in drugačne, dobre pa tudi slabe spomine na te mesece ali ta leta. Rad bi se zahvalil vsem generacijam, od prvih iz Peker in $\mathrm{z}$ Iga, do zadnje, ki so na ta način prispevale k obrambni naše skupne domovine. 


\section{TIMSKO DELO V SLOVENSKI VOJSKI}

\section{TEAM WORK IN THE SLOVENIAN ARMED FORCES}

Povzetek Na izbor članka je vplivalo dejstvo, da v organizaciji, kot je Slovenska vojska, premalo pozornosti namenjamo timskemu delu, čeprav je opredeljeno v normativnih aktih Slovenske vojske. Glavni cilj članka je prikazati pogoje za nastanek tima, kdaj se odločamo za timsko delo ter kateri elementi timskega dela so uporabni ali so lahko podlaga timskemu delu v Slovenski vojski (SV). Pri tem bom upošteval teoretična načela za oblikovanje timov in iz preučenih gradiv prikazal, kako in kdaj izbrati primerno strukturo skupine/tima, z opredelitvijo vloge posameznika v njej, vodje tima in pogojev, v katerih oblikujemo učinkovit tim. Paziti moramo na primer na klimo v timu in motivacijo za delo v timu, saj bomo le tako dosegli primerne rezultate. Namen članka je opozoriti na organizacijo, organiziranje in organiziranost, predvsem pa na dejavnike, ki vplivajo na dogajanje v timu, in na to, kako preprečiti negativne pojave v njem. Prikazal bom, kako se lahko rešujejo težave v procesu dela. Opozoril bom na teoretična načela pri oblikovanju timov ter opredelil, kateri elementi timskega dela so uporabljeni in so podlaga za izvajanje procesov v organizacijskih enotah Slovenske vojske. V sklepnem delu članka bom na podlagi izkušenj predstavil dejavnosti uveljavljanja timskega dela v Slovenski vojski s praktičnim primerom. Cilj pa je tudi prikazati pomembno vlogo vodilnega osebja oziroma vodij, ki sestavljajo in vodijo time.

Ključne Organizacija, organiziranje, organiziranost, usposabljanje, izobraževanje, besede skupina, tim, timsko delo, vojaška organizacija, ustvarjalnost, učinkovitost.

Abstract This article has been motivated by the fact that team work is not paid due attention, although it is stipulated by the legal norms of the Slovenian Armed Forces (SAF). The main purpose of this article is to show which requirements need to be met in order to build a team, which situations are appropriate for team work, and which elements of team work can be applied to observe as a basis of team work in the SAF. 
This article relies on theoretical principles that pertain to the formation of teams. Based on a study of relevant materials it recommends how and when we can determine an appropriate structure of a group/team, identify the role of an individual in a team, the team leader, and which conditions need to be fulfilled for a team to be successful. Good results can only be achieved in a good atmosphere and in a stimulating environment. This article describes the structure and organization principles of a team, in particular factors that influence team dynamics, and to show how negative developments can be prevented. It depicts how problems are being solved in the work process. In the conclusion, activities for the promotion of team work in the SAF are presented, based on a practical example. In addition, important roles of the management who compose teams and team leaders are summarized.

Key words Structure and organization principles, education and training, group, team, team work, military organization, creativity and efficiency.

\section{OPREDELITEV ORGANIZACIJE, ORGANIZIRANJA IN ORGANIZIRANOSTI}

Organizacija pomeni neko strukturo, organizacijski sistem. Poudarek je na nizu elementov, ki so na določen način sestavljeni in medsebojno povezani v določene odnose. Torej lahko rečemo, da organizacija združuje ljudi, ki so povezani med seboj, da bi dosegli določen cilj - zaželeno stanje. Organiziranje je proces, ki ga lahko razumemo kot urejanje oziroma proces urejanja organiziranosti. V zvezi z organiziranostjo se ponuja zahteva po usklajevanju in usklajenosti. To je posebno pomembno pri usklajevanju strukturnih sestavin med seboj in glede na cilje kot želene izide. Potrebne so še drugačne razsežnosti usklajevanja, npr. časovno usklajevanje, ki je sočasno stvar načrtovanja. Koordinacija je v tem primeru usklajevanje v okvirih sistema po nadsistemih in podsistemih. To je popolnoma skladno s teorijo sistemov. Organiziranost (sedanja, pretekla ali prihodnja) pa se pokaže kot urejenost oziroma stanje urejenosti organizacijskega sistema. Besedi urejenost in urejanje se kar ponujata za pojmovanje stanja in procesa organizacije.

\section{TIMSKO DELO}

\section{Uvodna pojasnila}

Le redko ljudje opravljajo svoje delo sami. Po navadi so združeni v manjše ali večje skupine. Kako dobro in koliko dela opravlja posameznik v skupini, je odvisno od njihovega znanja, usposobljenosti, notranje motiviranosti, kreativnosti, prizadevanja za skupno doseganje cilja, odnosa do dela, uporabe tehničnih sredstev in tehnologije. Vsekakor je vloga vodje v skupini zelo pomembna, odločilna, ker stalno vzdržuje tim kot sistem, v katerem prideta do izraza soodvisnost in povezljivost. 
Timsko delo je postalo oblika dela zato, da so se laže reševali problemi oziroma naloge. Učinkovitost tima ni odvisna samo od znanja in sposobnosti članov, temveč tudi od načinov in posebnosti posameznikovega vključevanja $v$ delo tima. $\mathrm{Ob}$ tem se člani tima srečujejo z osebnimi nalogami, pri katerih prideta do izraza tako konstruktivnost njihovih miselnih prispevkov kakor čustveno vključevanje $\mathrm{v}$ skupino. To pomeni, da smo na individualni ravni v glavnem priča usklajevanju miselnih razlik in pogledov na eni strani in uravnavanju medsebojnega doživljanja na drugi strani.

Dober tim je socialni sistem, ki daje posamezniku možnost, da izrazi svoje delovne in človeške vrednote. $\mathrm{V}$ dobrem timu prihaja do sinteze vrednot in njihove nove kakovosti. Zato ni najučinkovitejša tista skupina oziroma tisti tim, ki je sestavljen iz najučinkovitejših posameznikov, ampak tisti, ki v interakciji vseh svojih posameznikov daje najboljše rezultate. Torej ni dovolj, da so posamezniki kakovostni, kakovostna mora biti skupina, kateri pripadajo. Tudi strokovnjaki pri preučevanju organizacije dela v podjetjih in drugih ustanovah ugotavljajo, da za organizacije niso tako zelo pomembni odlični posamezniki, ampak in predvsem odlični delovni timi.

Lahko pa se pojavi težava, ker se veliko vodij prehitro zadovolji s sestavo tima. Zaradi njihove lahkomiselnosti se lahko zgodi, da tim ne daje pričakovanih rezultatov, predvsem zato, ker ne upoštevajo, da pri delu nastajajo težave. Lahko pride do nesoglasij in konfliktov med ljudmi, ki so mnogokrat vsakodneven pojav v večjih ali manjših sistemih ali med posamezniki. Posamezniki, združeni v skupino, ki so prej povsem složno opravljali neko drugo delo, se v novi skupini nekako ne znajdejo. Kdor pričakuje, da bo skupina oblikovana zaradi izvedbe določene naloge, začela takoj dobro sodelovati in dosegati dobre rezultate dela, je v veliki zmoti. Da bi se vsemu temu izognili in dosegli dobre rezultate, bi morali biti tako posamezniki kot delovne zahteve v medsebojni interakciji. Ustvariti bi morali primerno delovno okolje tako za posameznika kakor za organizacijo oziroma skupino.

Dva državna organa sta lahko podobna ali enaka po funkciji in pristojnostih, po številu zaposlenih, imata podobno ali enako informacijsko tehnologijo, vendar je eden uspešnejši od drugega. Marsikaj vpliva na storilnost, učinkovitost, uspešnost, toda vse bolj prevladuje spoznanje, da so ljudje ključen dejavnik. Zato je na mestu vprašanje, kako naj ravnamo z ljudmi, da bomo dosegli cilje organizacije in hkrati zagotovili zadovoljstvo zaposlenih. Vojaška organizacija se bistveno ne razlikuje $\mathrm{v}$ primerjavi z drugimi organizacijami. Ena od posebnosti pa je, da sta vodenje in ravnanje zaposlenih in poklicnih vojakov bolj celovito in natančno urejeni $s$ predpisi. Hierarhija zaposlenih, ki je sicer značilna za vse poklice, ni nikjer tako odločilna pri opravljanju delovnih dolžnosti kakor v sistemu, kot je vojska; v njej namreč velja razmerje nadrejenosti in podrejenosti, načelo enostarešinstva, načelo vojaške subordinacije itn. Z gledišča strokovne strukturiranosti pripadnikov vojaške organizacije pomeni razmerje nadrejenosti in podrejenosti sredstvo za zagotovitev funkcioniranja in strokovnosti delovanja vojaške organizacije. 
Veliko poveljujočega kadra je zavedeno zaradi takšnih razmerij v vojski in načina dela na vseh ravneh vodenja in kontrole. Znano je, da mnogi iščejo pravo bistvo svojega delovanja v smeri, ki vodi v specializacijo področja, ki ga dobro obvladujejo. S tem pa velikokrat poskrbijo samo za svojo prezaposlenost in zaradi dreves ne vidijo gozda. To je tudi razlog, da poveljniki navadno pozabljajo na svoje podrejene, ki so največkrat premalo zaposleni, premalo obremenjeni in nezadostno izkoriščeni glede na njihovo znanje in sposobnosti.

\section{POGOJI ZA NASTANEK TIMA}

Do sredine 20. stoletja je bilo stanje v zunanjem okolju - na trgu (v družbi nasploh) razmeroma stabilno in je omogočalo postavljanje lahko dosegljivih ciljev. Vodilni ljudje v podjetjih so si zamišljali organizacijo kot piramido. Vsak del piramide je moral doseči svoj cilj in zaradi tega se je zgradil sistem, ki je takšni organizaciji omogočil, da je uresničila vse cilje. Ljudje so bili administrativno vključeni v sistem. Bili so njegov sestavni del in vse je bilo mogoče zelo natančno in predvidljivo načrtovati. V tistem času so bile spremembe v okolju majhne in je bilo mogoče iz trendov preteklosti zelo natančno načrtovati prihodnost.

Takšno stanje ekonomičnosti je omogočalo razraščanje birokracije in gradnjo imperija. Delovni proces je bil za izpolnjevanje nalog razbit na veliko delov z razdrobljenimi procesi, ki so jih opravljali ljudje v funkcionalnih oddelkih. Rezultat je bil birokratska ohromljenost, pomanjkanje inovacij in visoki režijski stroški.

Takšna organiziranost je bila in je še marsikje v državni upravi in vojski, ki se najtežje spreminjata oziroma preoblikujeta. Organizacija državne uprave in vojske ni tako izpostavljena vplivom zunanjega okolja oziroma pritiskom trga in s tem prisiljena, da racionalno preoblikuje organizacijo in delovne procese. Konkurenca na trgu je postajala vedno večja, oblikovalci organizacij so potrebovali več novih idej in domiselnosti pri postavljanju ciljev in njihovi realizaciji. Hitrejši napredek so dosegli z vključevanjem ljudi v time, s tem so sprostili njihove ideje pri skupnem delu.

Tako kot se to uveljavlja $\mathrm{v}$ podjetjih in drugih organizacijah, ki so izpostavljene trgu zaradi novih zahtev, ne moreta ostati imuni na nove oblike organiziranosti niti naša državna uprava niti Slovenska vojska kot njen specifični del. Zaradi nenehnih zahtev okolja po zniževanju javne porabe, večji učinkovitosti in demokratizaciji sta prisiljeni, da spreminjata svoje upravljavske sheme.

To narekuje povečanje učinkovitosti veljavnih sistemov zaradi oblikovanja novih institucij, ki morajo podpirati spremembe $\mathrm{v}$ pravnem in političnem sistemu. Vsi sistemi v SV morajo postali timsko naravnani in notranje učinkoviti, saj se bo Slovenija s takšno organiziranostjo laže vključila v evroatlantske oziroma mednarodne integracije. 
Bolj kot do sedaj se bodo pokazale precejšnje razlike v napovedovanju in presojanju nekega problema, saj ljudje v enakih položajih ne reagirajo enako. Vsak posameznik v skupini ima svoje cilje in poglede pri reševanju kompleksnih situacij, nekateri so manj sposobni, drugi bolj nadarjeni. Da bi te razlike med posamezniki ublažili, lahko le z motivacijo o pripadnosti skupini pripeljemo skupino do uspešnega dela in do uresničevanja skupnih ciljev. Motiviranje zaposlenih mora biti temeljni cilj in celo želja vodilnega osebja. Če so ljudje zadovoljni, opravljajo delo po svojih najboljših močeh; največja odgovornost vodij skupin je ustvarjati notranjo harmonijo, zaradi oblikovanja visoko učinkovite in samostojne skupine.

Vodilno osebje v javni upravi ima razne naloge in pooblastila, odvisno od položaja v hierarhični strukturi. Med vodilno osebje štejemo vse tiste, ki vodijo: od vodje najmanjše organizacijske enote do ministra ali direktorja urada, agencije, zavoda itn.

Naloga vodij je, da s svojim znanjem iz posameznikov in njihove nadarjenosti izvlečejo najboljše oziroma da njihove pomanjkljivosti nadomestijo s prednostmi drugih. Zato ni dovolj, da imajo znanje samo iz vodenja, njihovo znanje mora biti obsežno, ker morajo poznati problematiko s posameznih področij, ki so združena v timu. Torej mora vodja tima komunicirati s strokovnjaki s posameznih področij in vzpostaviti takšno klimo, da zaposleni odprto, spontano in z občutkom za realnost prikažejo svoje vizije širšemu krogu zaposlenih, predvsem pa timu, ki mu pripadajo. Da bi bili vodje učinkoviti pri svojem delu, naj uporabljajo zelo preprosto metodo interakcije s sodelavci, ki se imenuje vodenje po zlatem pravilu: Ravnaj z drugimi tako, kot si želiš, da bi oni ravnali s teboj. To pravilo temelji na vljudnosti, ljubeznivosti in spoštovanju v odnosu do vseh ljudi, zlasti do ljudi, ki so podrejeni.

Vloga vodje v skupini je zelo pomembna in izpostavljena. Če vloga vodje ni že vnaprej določena, jo moramo oblikovati med prvimi. Z vlogo vodje je močno povezan proces socialnega vplivanja. Oblikovanje in vzdrževanje delovnega okolja, ki vzbuja veliko medsebojnega zaupanja, je ena najpomembnejših stvari, ki jih vodja lahko stori v skupini. Ključ do ustvarjanja prijetnega delovnega okolja, v katerem je visoka stopnja zaupanja, je odprava strahu iz delovnega okolja. V delovnih okoljih se pojavljajo nesporazumi ali prihaja celo do manjših ali večjih prepirov, toda nikogarne bi smelo biti zaradi tega strah. Ljudje izražajo svoja mnenja, povedo, kar mislijo, kaj želijo storiti, kaj si zamišljajo, kaj hočejo in drugo. Takšni sprejemajo le določeno vrsto nadrejenih, tistih, ki ustvarjajo ugodno psihosocialno klimo. Ni jih strah tudi, če naredijo napake, ki se pojavijo kljub skrbnemu premisleku in dobremu namenu. Uveljavljanje oziroma uvajanje timskega dela v Slovensko vojsko je nekoliko težja naloga, saj je to sistem z obvezno subordinacijo, disciplino in enostarešinstvom. Prepričan sem, da bi to nalogo laže izvedli z raznovrstnim izobraževanjem in usposabljanjem vseh zaposlenih, predvsem pa vodstvenega kadra, saj zaposleni danes potrebujejo vedno več novega znanja in veščin. Dosegli bi višjo stopnjo izobraženosti in usposobljenosti ter s tem bistveno hitrejši pretok potrebnih informacij. To bi seveda pripomoglo $\mathrm{k}$ zmanjšanju nepotrebnega odpora do kakovostnih sprememb. Eden od pristopov za spoprijemanje s spremembami 
iz okolja je koncept učeče se organizacije, ki temelji na izboljševanju sposobnosti organizacije, ki zahteva nenehen osebni razvoj in neprestano učenje posameznika. Le tako bi si omogočili preoblikovanje organizacije dela v vojaški strukturi in dialog z vsemi ustvarjalnimi $\mathrm{v}$ njej, in to na vseh ravneh odgovornosti. Z novim teoretičnim znanjem, s sprostitvijo ustvarjalne domišljije vseh zaposlenih in $\mathrm{Z}$ drugačnim pristopom do organizacije dela v naši vojski bi lahko dosegli boljšo organiziranost vojaške organizacije, delovnih sistemov in seveda delovne procese v njih. Kljub temu se morajo ohranjati pravila vojaške hierarhije in načelo vojaške subordinacije. Iz navedenega izhaja, da bi morali funkcijsko organiziranost vse bolj nadomeščati s procesno.

Slika 1:

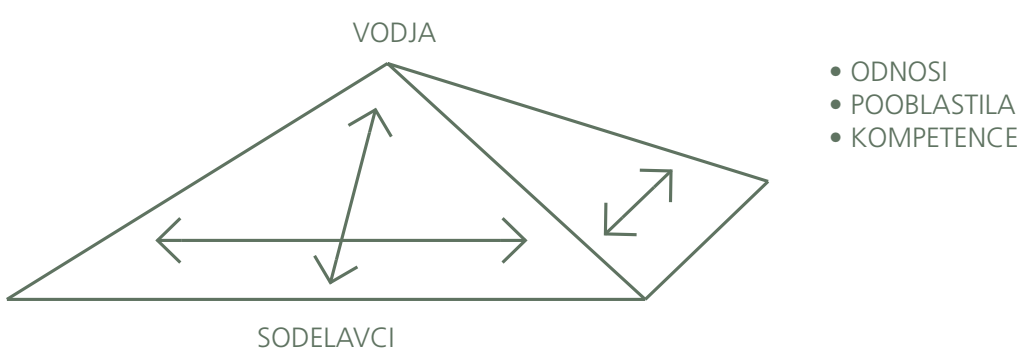

»ŽIVLJENJE NAJ BO STROKOVNO POLNO IN ČLOVEŠKO ZNOSNO! «

Učinek skupine ni odvisen samo od posameznikov, ampak predvsem od sinergijskega učinka, ki je povezan z emergenco (na novo nastajajoče stvarnosti), pri katerem iz skupine posameznikov nastane tim. Vse bolj postaja jasno, da se kakovostno delo lahko doseže večinoma z organiziranjem delavcev, da delajo skupaj. Posameznik lahko veliko spremeni v neki organizaciji, vendar pa imajo le redki dovolj znanja in izkušenj, da bi razumeli vse procese, ki nastajajo znotraj organizacije. Ob nekem dolgotrajnem projektu bi posamezniku motivacija verjetno sčasoma upadla. Timsko delo pa prepreči take in podobne težnje v organizaciji in zagotovi posameznikovo angažiranost za dokončanje naloge.

\section{ODLOČANJE ZA TIMSKO DELO}

V vsaki organizaciji, tako tudi v vojaški, se vsakodnevno srečujemo s težavami in z nalogami, ki jih je treba rešiti oziroma izvesti. Od obsega naloge je odvisno, ali bomo to dodelili posamezniku ali skupini. Težje naloge bomo prav gotovo zaupali določeni skupini ljudi, ker so za posameznika mnogokrat preobsežna in strokovno zahtevna. Nazadnje je treba ugotoviti, koliko članov naj šteje skupina in kako naj bo sestavljena glede na znanje ter osebnostne lastnosti. Skupinsko delo je sicer zelo pogosta in priljubljena oblika dela, vendar se tudi tukaj pojavljajo zelo različna stališča. Nekateri so kritični, češ da ima skupinsko delo naslednje pomanjkljivosti: 
neustrezno opredeljeno delo, izguba časa za usklajevanje, nejasno opredeljene dejavnosti posameznika, zbeganost, začetno oklevanje, zahajanje v podrobnosti, slabo razdeljene vloge, nespoštovanje organizacije dela, heterogenost skupine, zaverovanost posameznikov v lastne rešitve in različna raven predznanja. Med temi nasprotji pa so tudi prednosti. Tako sta na primer homogenost in heterogenost skupine, kot smo že v uvodu opozorili, neposredna vzroka za učinkovitost ali pa neučinkovitost skupine. Mnogi pa vidijo prednosti dela v skupinah, ker so opazili naslednje: hitro končano delo, sprotno sporazumevanje, skupno opredeljevanje stališč ipd. Prednosti naj bi izhajale iz homogenosti skupine, skladnosti sodelujočih, možne uskladitve mnenj, odprtosti članov skupine, različnih pogledov na problem, upoštevanja vseh mnenj in hitre izmenjave teh, spoštovanja predlogov, učinkovitega sodelovanja itn.

To, kar ljudje potrebujejo, je pripadnost, občutek, da so del nečesa, kar jim daje identiteto in varnost. Potrebujejo tudi občutek pripadnosti ustvarjalni skupini, ki poskuša doseči zanje nekaj dragocenega, vrednega truda. Če pogledamo v zgodovino, so bili ljudje resnično srečni, ko so bili popolnoma predani doseganju nečesa, za kar se je bilo vredno truditi. Če se hoče ustvariti samostojna skupina, se morajo predvsem upoštevati ljudje in zadovoljiti dve njihovi globoki notranji potrebi: po avtonomnosti in po pripadnosti skupini.

Ko sestavljamo tim, nam pomaga, če so glede na značilnosti članov zastopani vsi vidiki reševanja problemov. Če v timu prevladujejo »izvirni misleci« in »zaključevalci« implementatorji, manjkajo pa ljudje, ki bi spretno izbirali in ovrednotili ideje ter od tod izpeljali načrt, se takemu timu lahko pogosto dogaja, da zna navdušiti okolico za svoje ideje, a se velikokrat prenagli zaradi neizdelanosti zamisli. Tak tim počasi izgublja podporo med sodelavci, saj so načrti slabo izbrani in premalo konkretni, da bi bili uspešni. Pomembno je, da znamo prepoznati bistvene nagibe posameznikov in da vemo, da se je s treningom mogoče tudi priučiti veščin, ki so potrebne v fazah, ki morda nam niso najbližje.

Iz opisanega lahko ugotovimo, da ni povsem enotnega stališča, kakšna naj bo sestava skupine, dvomimo o pričakovanih rezultatih, zaskrbljeni smo zaradi hitrosti del itn. Naša želja pa je, da imamo skupino ljudi - TIM, ki lahko uspešno reši nalogo. Uspešno pomeni, da je naloga opravljena pravočasno in da so gospodarno izrabljeni tako notranji kot zunanji viri. Vsak član prispeva po svojih zmožnostih.

Spodnji diagram nazorno prikazuje strukturo dela $\mathrm{v}$ timu in notranjo procesnost, ki ustvarja želene rezultate. Potek dejavnosti pri organiziranju timskega dela je prikazan v naslednjem diagramu na sliki 2.

Pomembnost skupinskega oziroma timskega dela v vsaki organizaciji je očitna, saj večino časa preživimo v medsebojni interakciji v uradnih in neuradnih pogovorih, sestankih, krožkih, posvetih, projektnih in delovnih timih in podobno. Še posebej to velja za vodje na vseh ravneh, ki morajo redno komunicirati s sodelavci ter reševati probleme, ki se nanašajo na medosebne, delovne in poslovne zadeve. 


\section{OPREDELITEV SKUPINE}

Vsakdo izmed nas pripada neki skupini: delovni, športni, socialni, prijateljski, politični. Skupine se razlikujejo po nekaterih značilnostih, vendar ima vsaka tudi nekaj osnovnih potez, zaradi katerih jo lahko imenujemo skupina. Vsaka ima določeno število članov, to število pa bistveno spreminja odnose in procese, ki se razvijajo v skupini. Glede na število članov ločimo:

- diade, skupine z dvema članoma,

- triade, skupine s tremi člani, in

- druge oblike, skupine z več člani.

Slika 2:

Potek dejavnosti pri organiziranju timskega dela

Vir: Pavlič,

Tomaž,

Oblikovanje tima

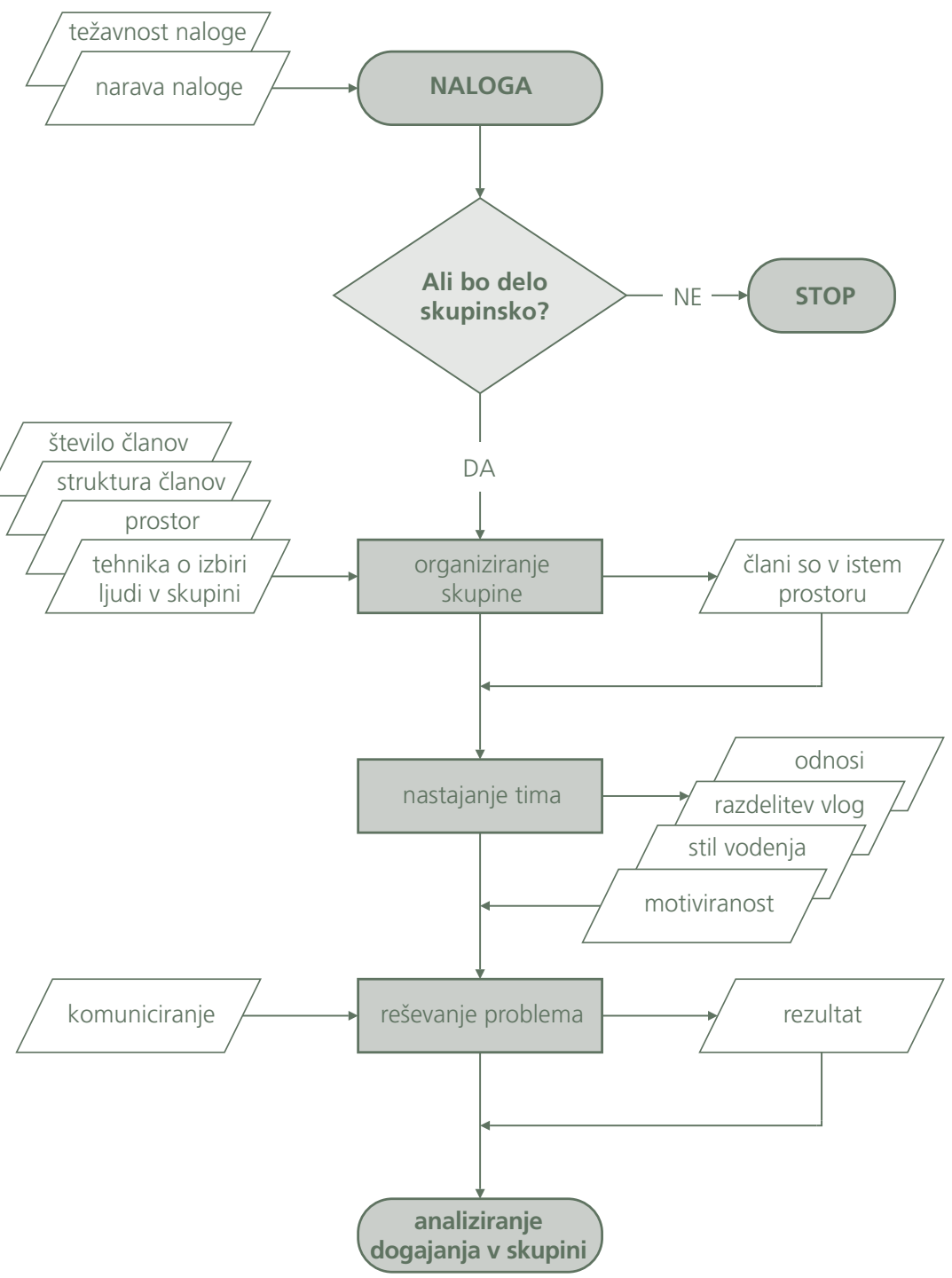


Posameznik se povsem drugače vede in komunicira v diadi kakor v triadi. V diadi so odnosi veliko bolj intenzivni in navezanost je obojestranska. V triadi se to že poruši, le v redkih primerih se to izraža $v$ vsestranskih odnosih. $Z$ večanjem števila članov tudi skupinske značilnosti bledijo. Pri številu več kot 15 članov v skupini lahko najdemo le eno ali nekaj skupnih potez. Predvsem se v velikih skupinah ljudje med seboj ne poznajo tako dobro niti nimajo realne možnosti, da bi vsakdo v skupini imel stike z vsemi.

Osnovna nujnost vsake skupine je sposoben vodja, okoli katerega se drugi člani združujejo, se z njim poistovetijo, omogoča jim uresničevanje teženj, ki jih sprožijo osebne potrebe. Najpomembnejši za skupino je vsekakor skupni cilj. Člani skupine s ciljem dosežejo svoj namen. Če so cilji in potrebe članov različni, je bolje cilje prilagoditi članom kakor poskušati spreminjati njihove potrebe. Ključ do visoko učinkovite skupine je zelo preprost - ključ je v harmoniji, ki so jo dosegli vsi člani skupine. Da nekemu številu ljudi lahko rečemo skupina, mora imeti naslednje značilnosti:

- skupina mora biti spoznavna in določljiva po članih, ki jo sestavljajo,

- imeti mora socialno strukturo, ki določa položaj člana in odnose med njimi,

- obstajati morajo recipročni odnosi, ki zagotavljajo stike in komunikacijo med člani,

- v skupini mora obstajati vloga posameznika, prek katere član sodeluje v skupini, brez njegovega dela skupina preneha obstajati,

- vsaka skupina ima svoje norme, po katerih član oblikuje svoje vedenje,

- člani skupine imajo določene skupne interese, ni nujno, da so natančno določeni,

- delovanje skupine mora biti usmerjeno k skupnemu cilju,

- skupina mora imeti določeno trajnost.

Skupine načeloma delimo na dve vrsti: formalne in neformalne. Formalne skupine imajo natanko določene naloge in cilje. Vsak posameznik ima $\mathrm{v}$ taki skupini določeno mesto oziroma položaj in naloge. Takšna skupina nastane z uradnim, formalnim aktom. Vnaprej ima določene vodjo, cilje, delovne naloge in pogoje za obstoj. Formalne skupine so glede na mesto, obseg in vsebino dela opredeljene v organizacijsko shemo (izrazit primer formalne skupine je vojska).

Neformalne skupine nastanejo z medsebojnim povezovanjem med ljudmi. Ukvarjajo se z zadevami, ki niso uradno delovne, ampak se nanašajo na zadovoljevanje interesov, potrebo po pomoči, po razvijanju prijateljstva in podobno. Neformalne skupine lahko podpirajo ali ovirajo cilje v skupini ali pa so do njih nevtralne. Organizacijska struktura in način vodenja močno vplivata na nastanek in vsebino delovanja neformalnih skupin. Nazoren primer nastanka takih skupin je uvedba dvoizmenskega dela, ki onemogoča neposreden stik med člani. Taka delitev lahko pripelje do negodovanja, če vodja postavlja v ospredje doseganje delovnih rezultatov, pa se lahko zgodi, da se neformalne skupine usmerijo proti nadrejenemu. 
V prihodnosti bo značilna uporaba skupinskega znanja v organizaciji. To skupinsko znanje se bo uporabljalo po formuli:

$$
\begin{gathered}
\text { znanje }=(\text { osebe }+ \text { informacije }) \times \text { skupinska uporaba }=\text { napredek } \\
\text { oziroma } \\
Z=(O+I) \times S U=N
\end{gathered}
$$

Ta formula lepo ilustrira nedeljivo povezanost znanja, informacij in skupinske uporabe, ki nedvomno vodi k napredku.

\section{OPREDELITEV TIMA}

Zgoraj navedene značilnosti skupin lahko ustvarijo napačno prepričanje, da je preprosto oblikovati skupino, ki naj bi delovala uspešno. Vendar v praksi to povsem ne drži, kljub znani teoriji in praksi. Kadar je v neki organizaciji veliko skupin, v katerih ni pravega sodelovanja, začne uspešnost take organizacije počasi »šepati«. Če skupine že same po sebi ne delujejo uspešno, se bodo še težje povezovale z drugimi skupinami, s katerimi opravljajo določena dela. V primerjavi s formalno delovno skupino lahko pomeni tim povsem novo kakovost in možnost. Ustvarjalni tim deluje kot umsko omrežje, ki presega formalno organizacijo posameznikov, skupin, delovnih enot ..., saj omogoča in pospešuje sproščanje ustvarjalnih potencialov nad osebno zmožnostjo posameznika.

Temeljne značilnosti ustvarjalnega tima so nadseštevnost

$$
(1+1>2) \text {, }
$$

vzajemni učinki, velika prožnost, napovedana moč in hitrost učenja, predvsem pa večja verjetnost in hitrost ustvarjalnih dosežkov. Tim se razvija v smeri nastajanja svojstvenega spodbudnega ozračja, kolegialnega prijateljstva, ustvarjalnega zanosa in notranje kulture, ki temelji na značilnih skupinskih vrednotah, vedenja, občutka za lepo, čuta za pravično in podobno.

Graditev tima lahko ponazorimo s sestavljanjem lego kock in izraz tim nam danes predstavlja ravno to: gradbene »kamne« v organizaciji. Le pravilna izbira in postavitev vsakega »kamna« nas pripeljeta do uspešnih timov in s tem

organizacije. Tim je skupina, v kateri imajo posamezniki skupen cilj le zato, ker se njihova strokovna usposobljenost, veščine in druge lastnosti ujemajo, skladajo z drugimi člani skupine. Kadar oblikujemo uspešne time, govorimo o dveh pomembnih sestavinah:

- izbiri članov tima in

- usposabljanju tima. 
Slika 3: Matrika usposabljanja in razvoja organizacije

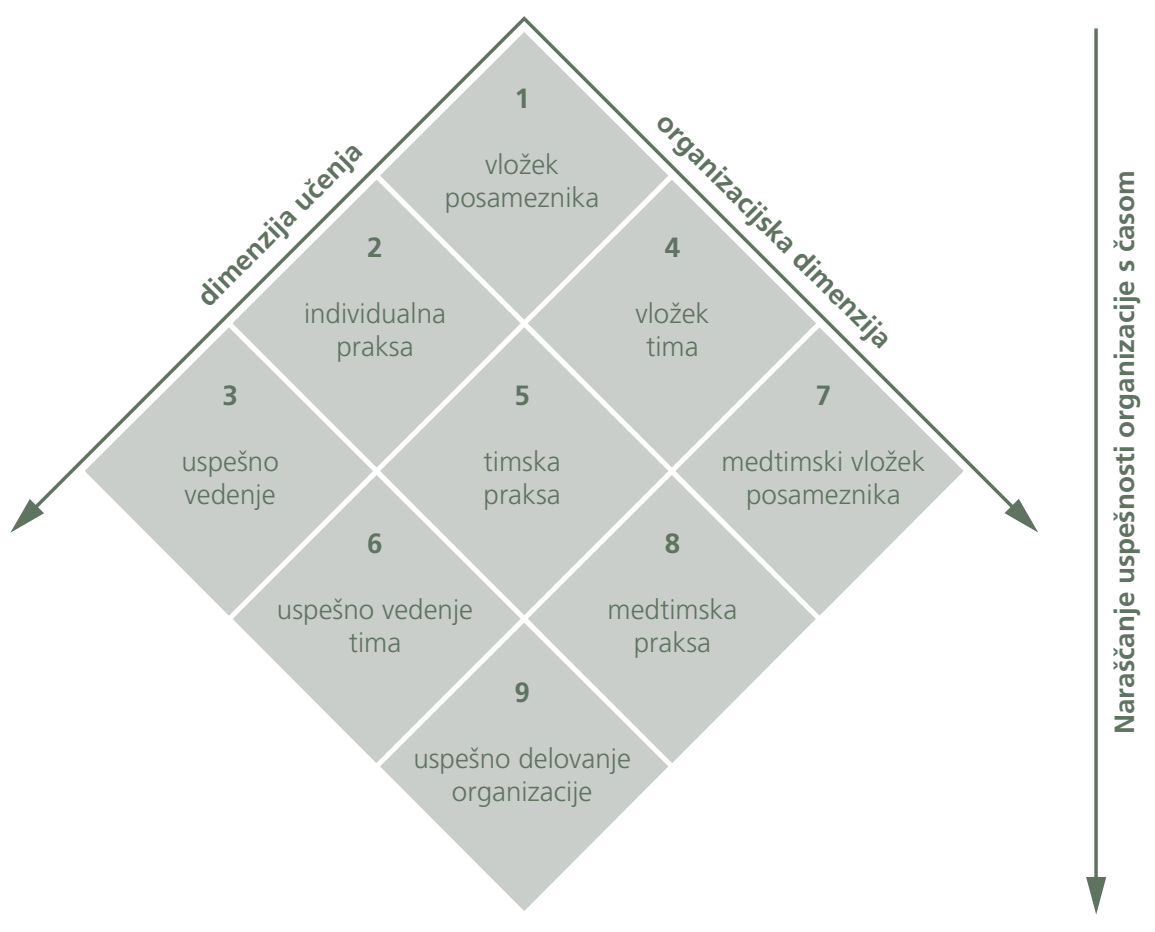

Usposabljanje tima se lahko začne na dva načina. Lahko začnemo z inštrukcijami o osnovah, ki opredeljujejo sestavljanje uspešnih timov. Lahko pa uporabimo drugo metodo, ki takoj začne z dano nalogo in člani sami prepoznavajo delovanje uspešnega tima. Zatem se usposabljajo in stalno ocenjujejo lasten razvoj ter končno obvladajo vse potrebne spretnosti. Tudi povezovanje med timi lahko urimo in pregledujemo ter tako zagotovimo uspešen razvoj celotne organizacije.

Slika 3 prikazuje povezanost med člani, timi in organizacijo. S tem sem hotel nazorno dokazati prepletenost, povezljivost in soodvisnost v procesu, ki se sproža v vsakem timu. Ta je oblikovan iz vrste strukturnih elementov, ki so na sliki nazorno prikazani.

Posamezniki in timi vlagajo znanje in sposobnosti za to, da bi čim bolje opravljali delo, rezultati pa kažejo, kako uspešni so bili. Sodelovanje med člani omogoča pridobivanje izkušenj in nenehno izobraževanje.

Razvoj tima se začne tedaj, ko se ljudje odločijo, da bodo sodelovali pri določeni nalogi. Oblikovanje tega lahko poteka različno. Uspešno oblikovanje naj bi potekalo po naslednji nekoliko skrčeni shemi, ki vsebuje naslednja vprašanja:

- Kaj so cilji organizacije?

- Kaj so cilji tima, skupine?

- Kaj so cilji posameznega člana?

- Kaj bi radi dosegli v posameznih časovnih obdobjih? 
- Kako bi radi to dosegli?

- Kaj pričakujemo od posameznih članov?

- Kaj pričakuje vodstvo od tima?

- Kdo odloča?

- Kako naj bodo odločitve opredeljene?

- Ali je tim ustrezno organiziran?

- Kakšna je morala, kultura dela v timu?

- Ali se da izboljšati?

- Kako uspešno timi sodelujejo?

- Kako navzgor in kako navzdol?

- Kaj in v čem je naša prednost?

- Ali lahko popravimo slabosti?

- Kateri so problemi?

- Ali imamo težave, ki bi jih morali upoštevati?

Po tej shemi naj bi bili člani sposobni odkrivati aktualne probleme. Predvsem je pomembno, da znamo ločiti razlike, ki nastanejo v primerjavi skupine in tima. V spodnji tabeli so glavne razlike med njima, čeprav sta lahko oba sestavni del v isti organizaciji.

Timski način dela je praktično nepogrešljiv takrat, ko pot reševanja, rešitev, število rešitev in način reševanja problema niso znani. $V$ takih primerih si želimo več mnenj, ki po usklajevanju dajo najboljšo rešitev. Poskus sestaviti skupino s podobnim, vendar pa heterogenim znanjem in s takšnimi osebnostnimi lastnostmi, ki omogočajo hitrejše nastajanje tima, mora biti namen in želja vsakega vodje.

Prednosti timskega dela se kažejo v več pogledih:

- znanje in informacije, ki jih ima tim, so praviloma večji od znanja kateregakoli člana,

- člani v timu lahko z razpravo in izmenjavo mnenj pridejo do raznih odločitev, $\mathrm{v}$ primerjavi z rešitvami, dobljenimi po ustaljenih poteh,

- člani, ki lahko vplivajo na odločitev, so tudi bolj sprejemljivi za skupne rešitve,

- zaradi sodelovanja pri reševanju problema člani bolje razumejo končne odločitve.

Prav tako ne smemo pozabiti na pomanjkljivosti timskega dela. Tako se lahko pojavi skupinsko razmišljanje, ki ne daje najboljših rešitev, prevlada posameznika v razpravi ali pa se v vnemi pri pomoči spregledajo cilji. Poraba časa je pogosta predvsem pri večjih skupinah in to je ena izmed napak timskega dela, ki pa seveda ni usodna. 
Tabela 1:

Razlike med timi in skupinami

\begin{tabular}{|c|c|}
\hline Skupine & Timi \\
\hline $\begin{array}{l}\text { Člani menijo, da so organizirani v skupine iz } \\
\text { administrativnih razlogov. Posamezniki delajo } \\
\text { neodvisno, le včasih, če so cilji skupni, pa v } \\
\text { povezavi z drugimi. }\end{array}$ & $\begin{array}{l}\text { Člani spoznavajo svojo medsebojno odvisnost } \\
\text { in vedo, da se osebni in timski cilji dosegajo } \\
\text { najuspešneje z vzajemno pomočjo. Ne izgubljajo } \\
\text { časa s prepiri okrog tega, kam spada določeno } \\
\text { delo, niti se ne poskušajo osebno okoristiti na } \\
\text { račun drugega. }\end{array}$ \\
\hline $\begin{array}{l}\text { Ker člani niso dovolj vključeni v načrtovanje ciljev } \\
\text { skupine, skušajo vso pozornost usmeriti sami nase. } \\
\text { Delo jemljejo preprosto kot najeti delavci. }\end{array}$ & $\begin{array}{l}\text { Člani sprejemajo delo za svojo last in združijo svoje } \\
\text { moči, ker so zavezani istemu cilju, ki so ga sami } \\
\text { pomagali postaviti. }\end{array}$ \\
\hline $\begin{array}{l}\text { Članom prej naložijo, kaj morajo delati, kot da } \\
\text { bi jih spraševali, kakšen bi bil najboljši način. } \\
\text { Predlogov ne spodbujajo. }\end{array}$ & $\begin{array}{l}\text { Člani prispevajo k uspešnosti podjetja z izvirnostjo, } \\
\text { talentom in znanjem, to pa omogoči boljše } \\
\text { doseganje ciljev tima. }\end{array}$ \\
\hline $\begin{array}{l}\text { Člani ne zaupajo ciljem svojih sodelavcev, ker } \\
\text { ne razumejo njihove vloge v skupini. Izražanje } \\
\text { lastnega mnenja ali nestrinjanje se obravnava kot } \\
\text { nezaželeno, ker ne podpira, temveč deli enotnost } \\
\text { skupine. }\end{array}$ & $\begin{array}{l}\text { Člani delajo v ozračju zaupanja, drug drugega } \\
\text { spodbujajo, da prosto izrazijo svoje mnenje, } \\
\text { predloge, občutke ali nesoglasja. Vprašanja so } \\
\text { dobrodošla. }\end{array}$ \\
\hline $\begin{array}{l}\text { Člani so zelo previdni pri tem, kaj povedo, tako } \\
\text { da je resnično razumevanje v skupini nemogoče. } \\
\text { Lahko se pojavi namišljeno igranje vlog, postavijo } \\
\text { se pasti v komuniciranju, v katere se lahko ujamejo } \\
\text { vsi, ki niso dovolj previdni. }\end{array}$ & $\begin{array}{l}\text { Člani si prizadevajo za odprto in pošteno } \\
\text { komunikacijo. Trudijo se, da bi razumeli stališče } \\
\text { vsakega izmed njih. }\end{array}$ \\
\hline $\begin{array}{l}\text { Člani so za delo lahko dobro usposobljeni, vendar } \\
\text { jih vodja ali drugi sodelavci ovirajo, da bi znanje } \\
\text { lahko uporabili. }\end{array}$ & $\begin{array}{l}\text { Člane spodbujajo, da razvijajo svojo usposobljenost } \\
\text { in da to, kar so se naučili, uporabljajo tudi pri delu. } \\
\text { Tim jih pri tem povsem podpira. }\end{array}$ \\
\hline $\begin{array}{l}\text { Člani se znajdejo v konfliktnih situacijah, za katere } \\
\text { ne vedo, kako bi jih rešili. Njihov vodja lahko } \\
\text { odlaga posredovanje, dokler ni povzročena že } \\
\text { resna škoda. }\end{array}$ & $\begin{array}{l}\text { Člani priznavajo konflikt za normalen pojav v } \\
\text { medčloveških odnosih. } V \text { takšnih primerih vidijo } \\
\text { priložnost za nove rešitve in ustvarjalnost. Trudijo } \\
\text { se, da konflikt rešijo hitro in konstruktivno. }\end{array}$ \\
\hline $\begin{array}{l}\text { Člani lahko sodelujejo ali pa tudi ne pri odločitvah, } \\
\text { pomembnih za skupino. Skladnost z mnenjem } \\
\text { vodje je pogosto pomembnejša kot uspešni delovni } \\
\text { rezultati skupine. }\end{array}$ & $\begin{array}{l}\text { Člani sodelujejo pri odločitvah, pomembnih za } \\
\text { tim. Razumejo, da mora vodja sam sprejeti končno } \\
\text { odločitev ali ko je treba hitro ukrepati. Cilj je vedno } \\
\text { le uspešnost tima in nikoli skladnost z mnenjem } \\
\text { vodje. }\end{array}$ \\
\hline
\end{tabular}

\section{DEJAVNOSTI UVELJAVLJANJA TIMSKEGA DELA V SLOVENSKI VOJSKI}

Spremembe, ki so se pojavile v zadnjem desetletju prejšnjega stoletja, vplivajo na postopen razvoj družbe in vse večjo globalizacijo. To je pogoj, da morajo biti organizacije hitre, fleksibilne in nenehno sposobne izboljšati svoje delovanje, če hočejo biti uspešne, zato se je Ministrstvo za obrambo RS v srednjeročnih smernicah delovanja opredelilo, da bo spodbujalo iniciativnost, samokritičnost, inovativnost in timsko delo med pripadniki Slovenske vojske. 
Organiziranje v SV pomeni postavljanje razmerij in struktur (npr. tehnične, komunikacijske, motivacijske in oblastno-avtoritarne), v katerih bo SV kot organizacija delovala najbolj uspešno. Vse te strukture so povezane med seboj v eni skupini ali pa slojeviti organizacijski strukturi.

Ko govorimo o vojaškem sistemu, moramo povedati, da je z razvojem tehnike in tehnologije ter človeških odnosov postalo sodobno bojišče velik izziv za poveljnike. Ti morajo obvladati nove koncepte, ki vključujejo novo tehnologijo, in upoštevati kompleksnost človeške narave in vse bolj sofisticiranega načina bojevanja. Poznavanje konceptov vključuje tudi obvladovanje ljudi oziroma maksimalno izkoriščenost njihovih razpoložljivih potencialov, da $\mathrm{V}$ pravem trenutku in $\mathrm{Z}$ najmanjšimi človeškimi izgubami dobijo premoč nad nasprotnikom.

\section{ORGANIZACIJA VOJAŠKE ORGANIZACIJE IN ORGANIZIRANJE DELOVNIH PROCESOV V NJEJ}

Posebnost je v tem, da sta vodenje in ravnanje zaposlenih ali poklicnih vojakov bolj celovito in natančno urejena s predpisi. Hierarhija zaposlenih, ki se sicer pojavlja $\mathrm{v}$ vseh poklicih, ni nikjer tako zelo izrazita kot v vojski.

Pomen hierarhije v vojaški organizaciji je najbolj viden v zakonu s tega področja, v podzakonskih aktih in drugih pravilih. To je zajeto v Zakonu o obrambi, Pravilih službe v OS, Pravilu štabnega dela in drugih dokumentih, ki veljajo in opredeljujejo odgovornost za ukazovanje in izvajanje ukazov. Zlasti za častnike velja, da so hkrati nadrejeni in podrejeni, torej so $\mathrm{v}$ ambivalentni vlogi. Za izvedbo prejetega ukaza odgovarjajo nadrejenemu, hkrati pa jim ta ukaz dovoljuje, da sami ukažejo podrejenim.

Ker je treba ukaze nemudoma izpolniti, steče postopek ukazovanja po hierarhični lestvici zelo hitro. Če z vidika učinkovitega delovanja vojaške organizacije ni na razpolago časa za posebno razmišljanje o tem, ali ukaz izpolniti ali ne. Zato je v večini vojaških organizacij uveljavljeno pravilo, da se mora ukaz izvesti takoj ter upoštevati njegovo vsebinsko in časovno dimenzijo.

\section{POSEBNOST VOJAŠKE ORGANIZACIJE}

Vojaški sistem je posebna oblika, ki jo lahko primerjamo z ekonomskim sistemom, saj tudi zanj veljajo podobne ekonomske in organizacijske zakonitosti kakor za normalno gospodarstvo. Z ekonomskega kakor tudi z organizacijskega vidika mora ekonomizirati in se organizirati z omejenimi viri (finance, tehnologija ...) ter upoštevati ekonomsko in organizacijsko logiko poslovnih in organizacijskih procesov. 


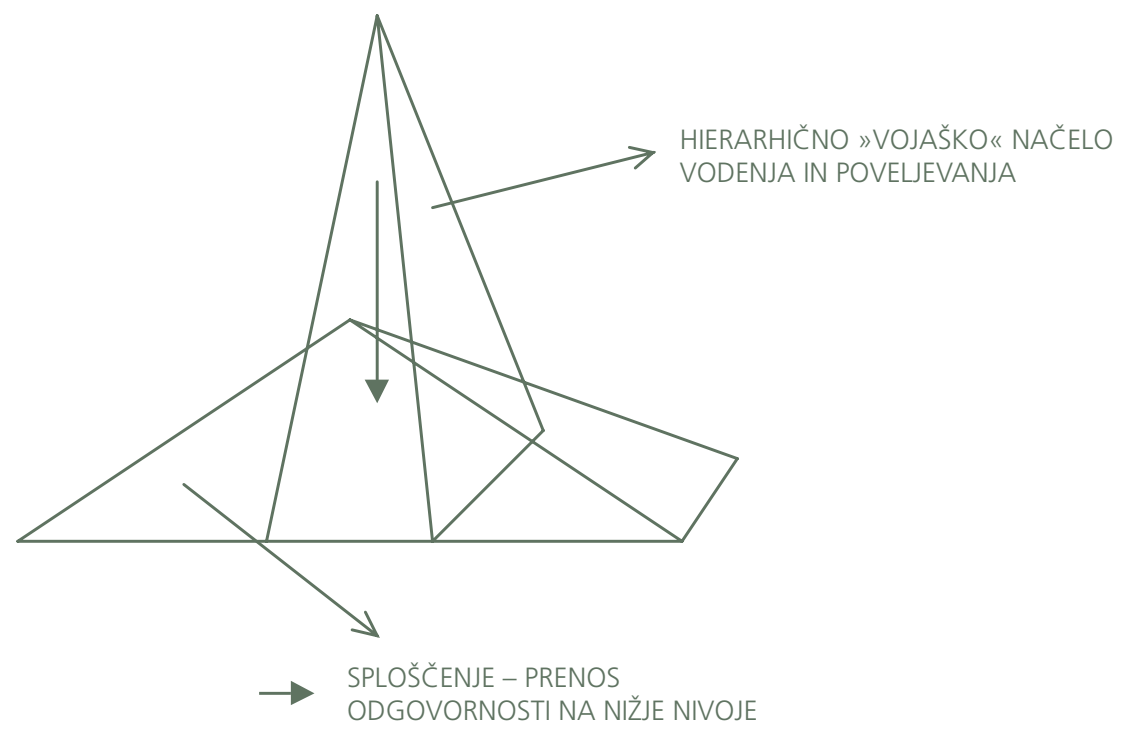

SODOBNO VOJSKOVANJE JE VOJSKOVANJE PAMETI IN RAZUMA, NE PA FIZIČNE IN OGNJENE MOČI!

Vojaški sistem je odvisen od ljudi kot elementov, ki ga sestavljajo, načina njihove organizacije (sistemska teorija), kulture njihovega vedenja, vojaškoorganizacijskih projektov, ki jih izpeljujejo, in rezultatov, ki so primerljivi in merljivi glede na zastavljene cilje in strategijo razvoja. Pri upravljanju vojaškega sistema-organizacije lahko uporabljamo podobne tehnike, kot jih obvladujejo menedžerji v podjetjih. Temeljna tehnika je podjetniški način organizacije in upravljanje vojske, ki temelji na pobudi posameznikov oziroma skupin, ki neprestano stremijo k izboljšanju vojaške doktrine, poveljevanja, organizacije in izvedbe vojaških nalog, ter na inovacijah na vseh področjih dela v vojski in podobno.

\section{PROCES VODENJA IN POVELJEVANJA V SV IN PODLAGA ZA ORGANIZIRANJE TIMSKEGA DELA}

Slovenska vojska se mora zgledovati po sistemih, ki so razvili učinkovito organiziranost in vodenje. Vodenje in poveljevanje morata zagotoviti glavni cilj delovanja SV. Dopustiti se mora več samoiniciativnosti v vodenju in poveljevanju - to posledično spremeni medosebne odnose v SV. Funkcijsko organiziranost mora vse bolj nadomeščati procesna organiziranost. Uspešnost SV je neposredno odvisna tudi od kulture okolja, saj njena naslonitev na vrednote okolja zagotavlja njeno uspešnost. Iz navedenega je razvidno, da morata vodenje in poveljevanja temeljiti na mnogih uspešnih menedžerskih prijemih. 
Poveljevanje je proces, v katerem poveljnik uveljavlja svoje pristojnosti ter vodi poveljstvo in podrejene enote v izvedbi sprejete naloge ali rešitvi problema. Proces poveljevanja obsega zmogljivosti, dejavnosti in postopke, ki jih poveljnik uporablja pri načrtovanju, organiziranju, vodenju in kontroli za izvedbo dejavnosti pri izvedbi neke naloge. Poveljevanje je pristojnost posameznika (poveljnika), pridobljena $\mathrm{z}$ zakonom, ko jo posameznik potrebuje za izvajanje funkcij uporabe enot in njihovega organiziranja ter kontrole pri izvajanju nalog. Namen poveljevanja je izpolniti naloge oziroma rešiti problem in s tem doseči zastavljen cilj. Objekti poveljevanja so poveljstva, enote in posamezniki.

Poveljevanje vključuje pristojnost in odgovornost za učinkovito izrabo razpoložljivih človeških virov za izvedbo sprejete naloge. Odgovornost za zdravje, moralo, disciplino in »blaginjo« podrejenih ter sprejem tveganja je sestavni del poveljevanja.

Poveljnik je odgovoren za vse, kar njegovo poveljstvo ali enota naredi oziroma česar ne naredi, in svoje odgovornosti ne more prenesti na drugega. Poveljnik je tisti, ki sprejme končno odločitev in je zanjo tudi odgovoren. Poveljnik delegira del svojih pooblastil glede vodenja poveljstva na druge ter spodbuja vzajemno zaupanje, tesnejše sodelovanje in timsko delo med vsemi člani poveljstva.

\section{PROJEKTNI TIM}

Za uspešno izvajanje nalog SV sta pomembna tudi izobraževanje in usposabljanje ljudi na vseh ravneh v SV. Dolgoročno oblikovanje pozitivnega pristopa zaposlenih pri izvajanju nalog je potrebno za izvajanje nalog doma in $\mathrm{v}$ tujini, $\mathrm{v}$ miru in izrednih razmerah. S tem bi povečali kakovost dela in zadovoljstvo pripadnikov SV. Preprečili bi izpad načrtovanih oblik usposabljanja in izobraževanja ter dosegli obvladovanje potrebnih vojaških obrambnih procesov, poleg tega pa tudi procesov za vzpostavljanje obrambne zagotovitve; s tem bi dosegli mednarodno povezljivost, zagotovili nacionalno varnost in kar je najpomembnejše - povečali bi bojno pripravljenost SV.

Predlagan je projekt, ki bi ga lahko uresničili na podlagi znanja in izkušenj zaposlenih na področju izobraževanja in usposabljanja v SV. Predstavljeni so idejni projekti oziroma zasnove - usmeritve za izvedbo projektov po predlaganem modelu.

Cilji projekta so:

1. spodbuditi v zaposlenih odnos »dobrega gospodarja«,

2. spodbuditi inovativnost in ustvarjalnost, dvigniti raven organizacijske kulture Slovenske vojske,

3. identifikacija zaposlenih s Slovensko vojsko,

4. zagotoviti pravočasno načrtovanje in pripravo kandidatov,

5. izboljšati stil vodenja in poveljevanja ter komunikacij,

6. ustvariti pogoje za normalen sistem poklicnega napredovanja. 
Projekt omogoča, da se s sistematičnim in ciljno programiranim izobraževanjem in usposabljanjem zaposlenih ustvarijo takšne ustvarjalne razmere za aktiviranje vseh intelektualnih potencialov, ki so v fazi nadaljnje gradnje SV in pomembnih odločitev.

Projekt ne omogoča hitrih učinkov in celotne nadomestitve zamujenih dejavnosti v preteklosti.

Nekatere pozitivne izkušnje iz preteklosti že imamo, saj sta izobraževanje in usposabljanje potekala usmerjeno in tudi z že določenimi ciljnimi skupinami. Te izkušnje lahko vgradimo v sistem nadaljnjega načrtnega izvajanja izobraževanja in usposabljanja zaposlenih.

Kadrovanje ima v Slovenski vojski pomembno t. i. funkcijo »prečnega prereza«. Posredno in neposredno vpliva na vsa področja dela. Kadrovanje v vseh oblikah izobraževanja je osredotočeno na vojaški menedžment najpomembnejših dejavnikov v obrambnih silah. Naša vizija je, da smo lahko le tako dobri, kot so dobri naši častniki, podčastniki in vojaki, zlasti stalne sestave. Torej mora biti vojaški menedžment sprejet in trdno zasidran v SV ter drugem delu MO kot izvajalcu sprejete politike izobraževanja. Po vsebini, odgovornosti in svoji vlogi umeščamo to vrsto menedžmenta k najpomembnejšim področjem vojaške obrambne politike.

Vojaškega menedžmenta ne oblikujejo le kadri in oddelki ali službe, ki so za to v Slovenski vojski in MO strokovno opredeljeni in pooblaščeni. Učinkovitost in uspeh »gospodarjenja« s kadri sta še zlasti odvisna od funkcionalnega sodelovanja vseh zaposlenih in tudi drugače vključenih, na vseh ravneh, v vojaški obrambni sistem. To velja predvsem za razvoj kadra, ki ima poseben pomen pri dolgoročnem zagotavljanju uspešnosti in učinkovitosti SV.

Izobraževanje in usposabljanje ter razvoj kadra potekajo v izredno dinamičnem okolju, zaradi najrazličnejših vplivov (spremembe varnostnih razmer, mednarodno povezovanje, nove tehnologije, omejitve zaposlovanja, različne izobrazbene in vojaškostrokovne osnove zaposlenih, fluktuacije idr.), zato morajo biti izobraževanje in usposabljanje ter razvoj kadra stalnica, ki sistemsko zagotavlja kvantitativno in kvalitativno potrebo po kakovostnih pripadnikih SV. Za izvajanje teh pomembnih elementov vojaškega obrambnega sistema pa morajo biti postavljeni ustrezni sistemi organizacije, vodenja in poveljevanja, koordinacije, načrtovanja in kontrole. Le s sistematičnim obvladovanjem vseh elementov oblikovanja celovitega sistema "gospodarjenja« s kadri lahko pričakujemo načrtovane in želene rezultate. V te dejavnosti morajo biti vključena vsa področja kadrovskega delovanja v SV in MO. V SV pričakujemo dolgoročen uspeh s potrebnim obvladovanjem procesov dela, v naši državi in z mednarodnem sodelovanjem, razvojem obrambnih sil, inovacijami, s posodabljanjem opreme in oborožitve ter predvsem s strokovnjaki na različnih področjih, ki bodo izobraženi in usposobljeni za izvajanje nalog v miru in izrednih razmerah ter vojni. 
Razvoj kadra v Slovenski vojski še ni uporabljen optimalno. Prizadeva pa se, da bi bili človeški viri uporabljeni glede na njihovo usposobljenost ter da bi se ti ljudje naučili timskega način razmišljanja in delovanja. Takšen način delovanja se mora uveljaviti na vseh ravneh SV. Seveda bosta za to potrebna stalno izobraževanje in intenzivno motiviranje za delo v timu. Operativni razvoj, načrtovanje usposabljanja kadra na ravni poveljstev, enot in zavodov ter tehnične postopke izvajajo strokovni sodelavci, seveda s koordinacijo strokovnih služb GŠSV ter SOK MORS. Vendar ti ne smejo pozabiti, da sta usposabljanje in delo v poveljstvih velika preizkušnja za timsko razmišljanje in timsko delo.

V CVŠ, v katerem so organizacijske enote in vodstva šol ter strokovni delavci in predavatelji ter vrsta poveljnikov enot, potekajo klasični procesi timskega dela. Če se tega ne upošteva, prihaja do zastojev v izobraževanju in usposabljanju. Organizacija v SV zahteva nemoteno izvajanje dela in za to sta potrebna določena stopnja izobraženosti in usposobljenosti pa tudi oblikovanje ciljnih skupin, ki bodo na podlagi timskega dela realizirale poti za kariero ter občutek za komunikacijo in identiteto v ožji in širši skupini.

\section{Primer projektnega tima}

1. Projektni svet: za izdelavo strategije izobraževanja in usposabljanja

2. Projektni tim: za izdelavo strategije izobraževanja in načrt za leto 2001: izvaja skupina strokovnjakov višjih častnikov od majorja do polkovnika

3. Strokovni sodelavci iz MO: se vključujejo po potrebi

4. Zunanji sodelavci: visoke šole, fakultete, izvajalci izobraževanja (po potrebi)

5. Drugi sodelavci: vključijo se po potrebi še z drugih področij, odločitev o tem sprejme po predlogu vodja projekta ali projektni svet

Člani projektne skupine (strokovni sodelavci in zunanji sodelavci) so vključeni samo občasno, ko so potrebne posamezne konzultacije ali opredelitve glede posameznih problemov pri izvajanju projekta. Celotno izvedbo projekta vodijo vodja projekta in član projektnega tima »ppk. NN«ter vodje podprojektov.

Nekatera področja se obdelajo z občasnim vključevanjem sodelavcev. Konzultacije in dodatne usmeritve so praviloma pridobljene od projektnega sveta.

Sklep Zaradi velikih izzivov iz okolja bo morala SV v prihodnosti upoštevati nove »prijeme« znotraj vodenja in poveljevanja ter same organizacije kakor tudi delovnih procesov v njej. Izzivi se bodo morali izražati v težnji, da je uveljavljanje timskega dela nujnost, saj je sodobno vojskovanje prepleteno in soodvisno zaradi mnogih znanj in veščin. Le na podlagi tega lahko poveljnik izbere najustreznejšo odločitev. V zvezi s tem čakajo skupine in posameznike vse večje zahteve po višji stopnji znanja in spretnosti, sposobnosti in iznajdljivosti. Zato bo tudi pomembno, da bo posameznik stalno motiviran za skupinsko/timsko opravljanje nalog. To delo ne bo več nekaj, kar bi bilo prepuščeno posamezniku. Zaradi vse večjih zahtev na delovnem mestu se bo moral stalno socializirati ter se permanentno izobraževati in usposabljati. Znova 
bi rad poudaril - in to se mi zdi zelo pomembno in koristno za SV, da je eden od pristopov za spoprijemanje s spremembami iz okolja - koncept učeče se organizacije. SV bi morala biti dovolj motivirana, da bi se izboljševale usposobljenosti njenih notranjih organizacij oziroma organizacijskih enot ob nenehnem osebnostnem razvoju in neprestanem učenju vseh njenih pripadnikov. Le pod tem pogojem bi se ohranjala učeča se organizacija, ki se imenuje - Slovenska vojska.

Visoka stopnja znanja in motiviranosti zaposlenih v SV bo omogočila, da se bodo zmanjšale blokade $\mathrm{v}$ ravneh $\mathrm{v}$ organizacijski hierarhiji in da se bo funkcijska organiziranost vse bolj nadomestila s procesno.

Moj prispevek o potrebi timskega dela v SV je nastal v obsegu, kakršen je bil potreben, če sem hotel zagovarjati potrebo po takšnem načinu dela. Ta prispevek je bil potreben tudi zato, ker se o tej problematiki še vedno premalo razpravlja, čeprav je mogoče čutiti potrebo po timskem načinu dela, torej po neki stalni povezljivosti ljudi in njihovi soodvisnosti. Ne smemo pozabiti, da mora to potekati v razmerah vojaške hierarhije, enostarešinstva in vojaške subordinacije. Praksa je pokazala, da sta se v enotah, poveljstvih in drugih organizacijskih strukturah, v katerih se je timsko delo začelo uporabljati bolj ali manj spontano, visoko dvignila motiviranost in občutek pripadnosti skupini/timu. Iz spontanih oblik se bo vsekakor prešlo na sistemsko, saj se v SV to vse bolj poudarja.

Za timsko delo so potrebni nekateri pogoji, ki morajo vključevati sistemska in ne spontana prizadevanja, še predvsem pri vodenju in poveljevanju. Le tako lahko dosežemo skupno vizijo - uspešen vojaški obrambni sistem, ki bo lahko opravil svoje naloge uspešno in učinkovito. Delovanje v timu bi bilo učinkovitejše in ravno to (učinkovitost in odličnost) zahteva naš kodeks, ki ni v nasprotju z zakonodajo na obrambnem področju. Vsekakor bi bilo umestno, da bi v podzakonskih predpisih potencirali to naravo dela, saj je edina alternativa pred stresi in frustracijami, ki jih doživlja posameznik, če je izoliran.

1. Ambrož, Milan, Učinkovita izraba virov v delovni skupini, Organizacija, letnik 32, št. 5, Kranj, maj 1999.

2. Bergant, Andrej, O analitiki dela, Organizacija, letnik 33, št. 9, Kranj, november 2000.

3. Boškovič, Desimir, Model formiranja organizacije za 21. stoletje, Organizacija, letnik 32, št. 5, Kranj, maj 1999.

4. Brejc, Miha, Ljudje in organizacija v javni upravi, VUŠ, Ljubljana 2000.

5. Kovač, Bogomir, Menedžerske metode in upravljanje Slovenske vojske, Dedalus, Ljubljana 1994.

6. Kralj, Janko, Pojmovanje znanosti o organizacijah, Organizacija, letnik 33, št. 7, Kranj, september 2000.

7. Kobentar, Jože, Izdelava strategije izobraževanja, GŠSV, Ljubljana 2001.

8. Lipičnik, Bogdan, Ravnanje z ljudmi pri delu, GV, 1998.

9. Mayer, Janez, Nastajanje celostnega pogleda - ključ za ustvarjalnost tima, Organizacija, letnik 34, št. 7, september 2001. 
10. Merc, Božidar, Vojstvo 1/96, Vojaška dolžnost in kazenska odgovornost, MORS, 1996.

11. Možina, Stane, Management, Didakta, 1994.

12. Mulej, Matjaž, in soavtorji, Dialektična in druge mehkosistemske teorije, Maribor 2000.

13. Nanut, Karlo, Učna gradiva CVŠ, Ljubljana 2000.

14. Pavlič, Tomaž, Oblikovanje tima, Poveljniško-štabna šola, Poljče 2001.

15. Tušek, Maks in Matej, Psihologija športa, Ljubljana 1994.

16. Tracy, Brian, Vrhunsko vodenje, prevod Saša Deleja in Maja Lihtenvalner, Vernar cosulting, Bled 2000.

17. Gradivo za seminar: Razvijanje timov II, SinesiS, d. o. o., Ljubljana 2001.

\section{Notranji viri}

1. Smernice za delo Ministrstva za obrambo do leta 2004, MORS, Ljubljana, februar 2001.

2. Poslovnik Generalštaba SV, GŠSV, Ljubljana, julij 2001.

3. Pravila štabnega dela, GŠSV, Ljubljana 2000. 


\title{
PROLIFERACIJA OROŽJA ZA MNOŽIČNO UNIČEVANJE - JRKB/E: NOVODOBNI IZZIV VARNOSTNIM SILAM V BOJU PROTI TERORIZMU1
}

\author{
PROLIFERATION OF CBRN/E WEAPONS: \\ A NEW CHALLENGE FOR SECURITY FORCES \\ IN COUNTER-TERRORISM
}

Povzetek Mednarodna javnost se srečuje s tretjo generacijo teroristov. Globalni džihad (sveta vojna) je spremenil svojo različico delovanja, saj posamezniki ali skupine delujejo tako, da sledijo voditeljevi nameri brez dejanskih navodil oziroma neposredne povezanosti s centralnim vodstvom. Glavno komunikacijsko orodje novodobnih teroristov je postal internet, hkrati pa je za tretjo generacijo teroristov značilna spremenjena vloga religije in ideologije. Dela islamskega učenjaka Ibn Taymija iz 13. stoletja, ki so obravnavala dolžnosti džihada, so se umaknila iz ospredja in niso več temeljna ideološka baza za globalno delovanje džihadistov 21. stoletja. Nova generacija teroristov prevzema svojo indoktrinacijo oziroma religiozno ideologijo od novodobnih islamskih radikalnih ideologov, objavljeno na internetu. Vodilna taktika uresničevanja nove ideologije in novih smernic džihada so serijska obglavljanja, posneta in predvajana na internetu in TV. Svojo taktiko pa džihad dopolnjuje z množičnimi izobčenji (takfir) članov terorističnih skupin, s čimer opravičuje umore muslimanov in do skrajnosti povečuje prag strpnosti do najhujših oblik nasilja med fanatičnimi ekstremisti. Ugrabitve, javna predvajanja mučenj in usmrtitev talcev ter izsiljevanja za visoke odkupnine postajajo eden pomembnejših virov financiranja džihada. Spremenjena taktika in nova ciljna interesna območja postajajo prednostna, vzporedno pa se dinamično spreminjata strategija in taktika globalnega boja proti terorizmu. Asimetrija ni več značilen vzorec oziroma termin, ki bi zadostno opisal in definiral nove različice delovanja džihada. Internetno organiziran informacijski kaos ustvarja in problematizira inter- in intrakomunikacijo znotraj mednarodne teroristične mreže, kar nevarno množi morebitne grožnje. Razvoj visokih tehnologij prehaja nacionalne meje, ki so vse poroznejše in ranljivejše, svet je vse manjši. Sproženje namernega izbruha bolezni, množične žrtve in splošna destrukcija so scenariji, ki dosegajo kritično raven oziroma se njihova magnituda nemoteno in eksponentno 
povečuje. Ni več vprašanje, ali lahko posameznik ali skupina ekstremistov uporabi biološko, kemično ali primitivno izdelano jedrsko orožje. Filozofija takšnega enkratnega uspešnega napada je preprosta, zgodili se bodo naslednji in množične žrtve so logično nadaljevanje. Orožje za množično uničevanje - JRKB/E - je že v novih, napačnih rokah, kar mednarodno skupnost oziroma mednarodni varnostni sistem postavlja $\mathrm{v}$ razmeroma nevarno območje. Biološko in kemično orožje sta »orožji prihodnosti« in bosta $\mathrm{v}$ kombinaciji z radiološkim in jedrskim orožjem najpogosteje uporabljeni na zgodnjih stopnjah konflikta, kar bi destabiliziralo varnostni sistem in logistično bazo ter povzročilo njun zlom.

Vsi napori, da se preprečijo pridobivanje, proizvodnja in kopičenje orožja za množično uničevanje, so odvisni predvsem od sposobnosti in pripravljenosti varnostnih sil. Vrhunsko opremljena varnostna sila že dolgo ni edini pogoj za uspeh v boju proti hitremu širjenju orožja za množično uničevanje oziroma v boju proti terorizmu. Ciljno izobraževanje in vzporedna osebnostna rast posameznikov v varnostnih silah ter večdimenzionalnost varnostne sile kot celote so eden izmed temeljnih pogojev, da grožnjo uporabe orožja za množično uničevanje ter sisteme za njegovo širitev obvladujemo oziroma preprečimo. Glavno sporočilo članka je namenjeno odpravi pomanjkanja razumevanja, da je posebno in za varnostne sile posebej prirejeno naravoslovno znanje na področju JRKB/E bistveno in bi moralo predstavljati ultimativno filozofijo zaščite varnostnih sil. Varnostne sile morajo najprej preživeti, da bi lahko zmagale, ščitile in zaščitile oziroma izpolnjevale ter izpolnile svoje temeljno poslanstvo.

Ključne besede

Abstract The international community is facing a third generation of terrorists. Global Salafi Jihad changed its course of action by following the "leader's design" without being specifically guided, informed or attached to the central strategic leadership. The Internet has become the terrorist's major tool of communication. The modification of the role and relationship to Islam and Islamic ideology, replaced the original Ibn Taymiya's philosophy of the 13th Century. The new generation of terrorists accustom their religious indoctrination from new age radical Islamic $t$ ideologists and from web sites and other media. The leading and unacceptably cruel web site's executive philosophy motivated the recording and broadcasting of decapitations along with unlimited excommunications, so called Tackfir, and causing the escalation of violence among Islamic "holy warriors" of the 21st Century. Kidnappings, hostage takings, ransom demands and extortion represent important sources of their "holy missions" financial backing. The new age terrorist's tactical concept and targeted areas of interest, in regards to counter terrorism have become a priority. Asymmetry is no longer the leading and sufficient term by which the new tactics and combat techniques of Jihad can be described or defined. The organized chaos regarding intraand intercommunication between the "holy warriors" and their strategic headquarter within the international terrorist network is multileveled and has varying degrees of 
possible threats. With advanced technologies and a smaller world with more open borders, the ability to unleash mass sickness, death, and destruction today has reached a greater magnitude. A lone madman or nest of fanatics with a bottle of chemicals, a batch of plague-inducing bacteria (virus), or a crude nuclear bomb, can threaten or kill tens of thousands of people with a single act. Weapons of mass destruction (WMD/CBRN/E- weapons) have already spread into new hands. These weapons pose a grave and urgent threat to international security. It is no longer questioned that use of biological and chemical weapons is a "likely condition of future warfare" and that these and nuclear weapons are likely to be used "early in the conflict to disrupt a security system and logistics".

Efforts to prevent certain groups from obtaining, manufacturing, or retaining these weapons crucially depend on the readiness of security forces. Well-equipped security forces are no longer enough. Education is crucial to triumph over an adversary who threatens or uses these weapons and their associated delivery systems. Therefore, the major message of the article is based on the extensive lack of understanding that a special and adjusted education system regarding WMD/CBRN/E- weapons should be the ultimate and is the only possible direction for security forces to ensure their survival, triumph, and ability to protect.

Key words CBRN/E-weapons, proliferation, security forces, education, terrorism. 
Slikovno gradivo

\section{Photos}


Slika 1:

Ob vstopu v

mednarodno

podatkovno

bazo PAIS

International

leta 2010

Picture 1:

On the occasion

of the PAIS

International

database

indexation in

2010

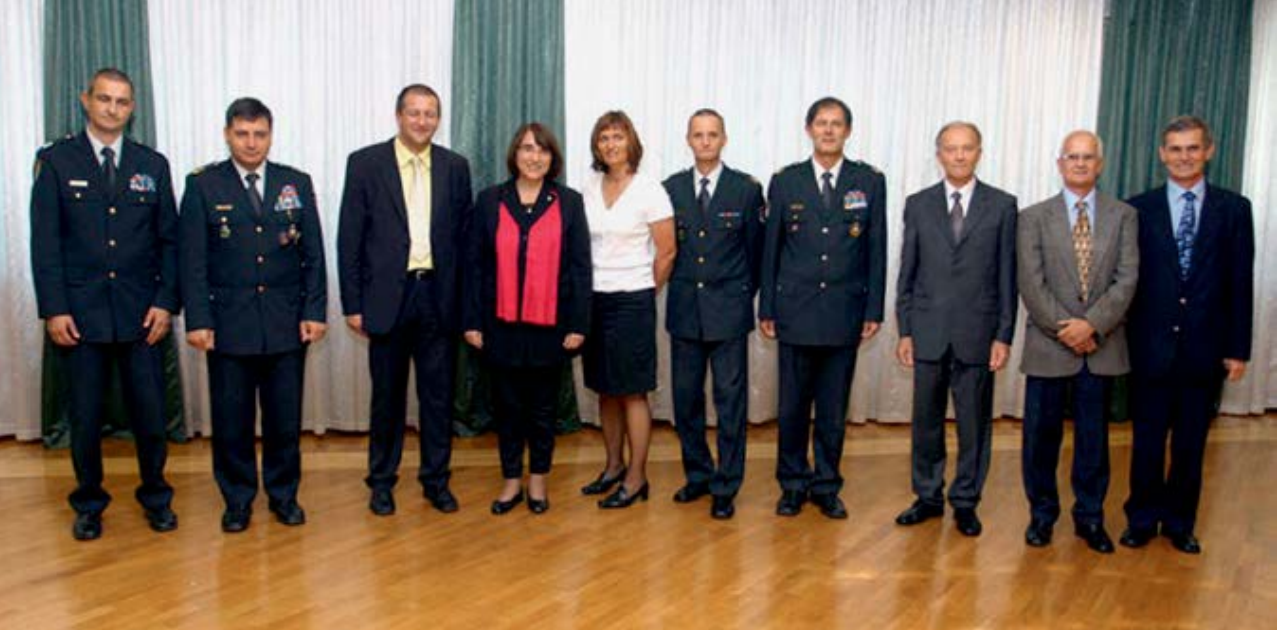

Od leve proti desni: VVU XIV r. dr. Denis Čaleta, član uredniškega odbora; generalmajor mag. Alojz Šteiner, načelnik Generalštaba Slovenske vojske; dr. Uroš Svete, član uredniškega odbora; dr. Ljubica Jelušič, ministrica za obrambo; mag. Liliana Brožič, odgovorna urednica; brigadir mag. Branimir Furlan, glavni urednik; brigadir mag. Andrej Osterman, član uredniškega odbora; dr. Janez Slak, namestnik direktorja Javne agencija RS za raziskovalno dejavnost; dr. Andrej Anžič, član uredniškega sveta; brigadir v pokoju Alojz Jehart, nekdanji član uredniškega odbora

From left to right: Senior Military Specialist, Class XIV (OF-5) Denis Čaleta, PhD, member of the Editorial Board; Major General Alojz Šteiner, MSc, Chief of the General Staff of the Slovenian Armed Forces; Dr Uroš Svete, member of the Editorial Board, Dr Ljubica Jelušič, Minister of Defence; Liliana Brožič, MSc, Managing Editor; Brigadier General Branimir Furlan, MSc, Executive Editor; Brigadier General Andrej Osterman, MSc, member of the Editorial Board; Dr Janez Slak, Deputy Director of the Slovenian Research Agency; Dr Andrej Anžič, Member of the Editorial Council and Brigadier General (Ret) Alojz Jehart, former member of the Editorial Board. 
Slika 2:

Ob 15-letnici

izhajanja

Sodobnih

vojaških izzivov,

december 2013

Picture 2:

On the occasion

of the $15^{\text {th }}$

anniversary

of the

publication of

Contemporary

Military

Challenges,

December 2013

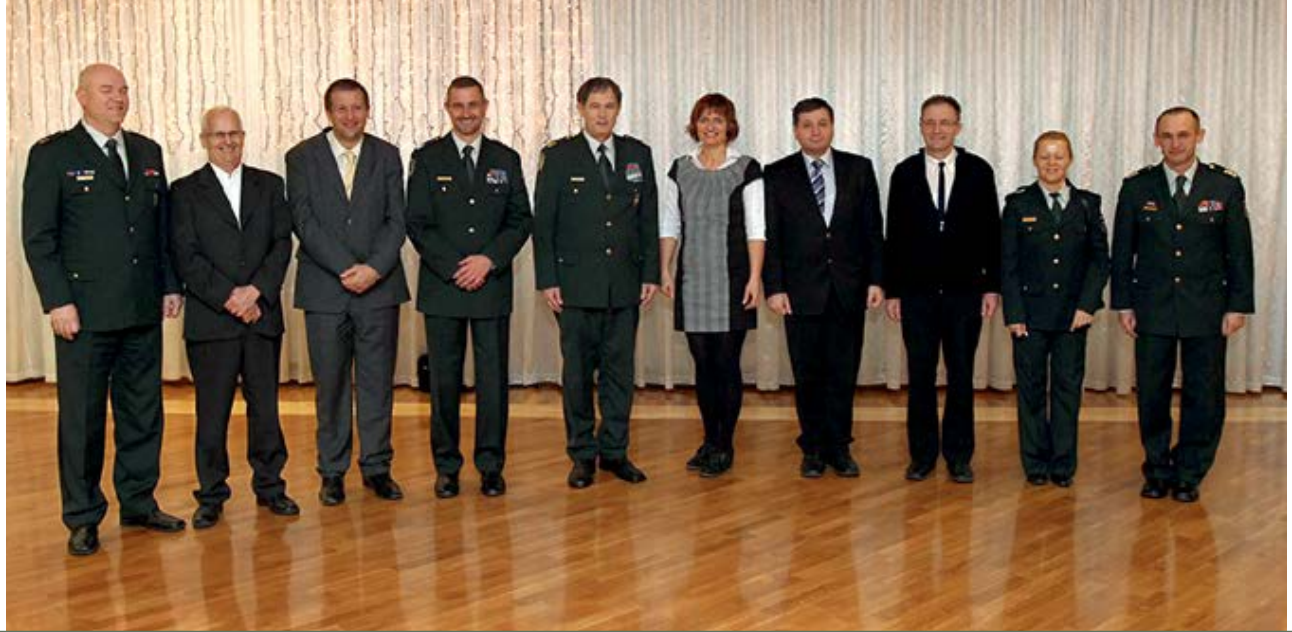

Od leve proti desni: polkovnik dr. Boris Rutar, član uredniškega odbora; dr. Andrej Anžič, član uredniškega sveta; dr. Uroš Svete in VVU XIV r. dr. Denis Čaleta, člana uredniškega odbora; brigadir dr. Andrej Osterman, glavni urednik; dr. Liliana Brožič, odgovorna urednica; generalmajor mag. Alojz Šteiner, nekdanji glavni urednik; polkovnik v pokoju mag. Evgen Primožič, nekdanji glavni in odgovorni urednik; VVU XIII r. dr. Valerija Bernik in polkovnik dr. Tomaž Kladnik, člana uredniškega odbora

From left to right: Colonel Boris Rutar, PhD, member of the Editorial Board; Dr Andrej Anžič, member of the Editorial Council; Dr Uroš Svete and Senior Military Specialist, Class XIV (OF-5) Denis Čaleta, PhD, members of the Editorial Board, Brigadier General Andrej Osterman, PhD, Executive Editor;

Dr Liliana Brožič, Managing Director; Major General Alojz Šteiner, MSc, former Executive Editor; Colonel (Ret) Evgen Primožič, MSc, former Managing and Executive Editor; Senior Military Specialist, Class XIII (OF-4) Valerija Bernik, PhD, and Colonel Tomaž Kladnik, PhD, members of the Editorial Board. 
Avtorji

Authors 


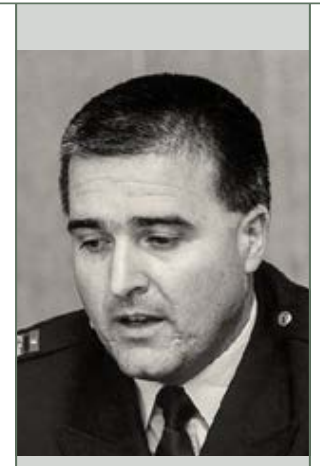

Iztok Podbregar

Generalpodpolkovnik dr. Iztok Podbregar je leta 1985 končal šolanje na Letalski vojaški akademiji. Leta 1991 se je pridružil Teritorialni obrambi, v kateri je bil načelnik odseka za letalstvo. Med letoma 1995 in 1998 je bil namestnik načelnika Generalštaba Slovenske vojske. Leta 1997 je magistriral na Fakulteti za organizacijske vede, aprila 1998 pa je bil imenovan za načelnika Generalštaba. Naslednje leto bil povišan v čin generalpodpolkovnika. Leta 2000 je doktoriral na Fakulteti za organizacijske vede. Leta 2001 je končal aktivno vojaško kariero in postal ministrski svetnik za obrambo v Uradu predsednika Vlade Republike Slovenije. Od leta 2002 do 2006 je bil direktor Slovenske obveščevalno-varnostne agencije, od leta 2004 do 2006 pa tudi nacionalni koordinator za boj proti terorizmu in svetovalec predsednika $\mathrm{RS}$ za nacionalno varnost. Leta 2006 je bil habilitiran v izrednega profesorja in se posvetil akademski karieri. Bilten Slovenske vojske je začel izhajati na njegovo pobudo, bil je tudi njegov prvi glavni urednik od leta 1999 do 2001.

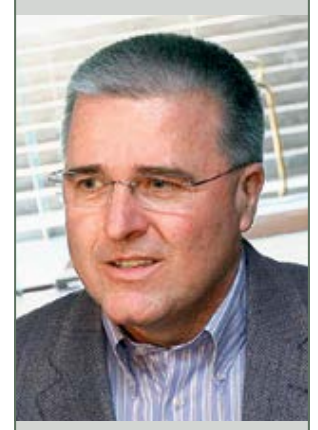

Lieutenant General Iztok Podbregar, PhD, graduated in 1985 at the Air Force Academy. In 1991, he joined the Territorial Defence, where he worked as Head of the Aviation Department. Between 1995 and 1998, he was Deputy Chief of the General Staff of the Slovenian Armed Forces. In 1997, he earned his master's degree at the Faculty of Organisational Sciences and in April 1998, he was appointed Chief of the General Staff. The following year, he was promoted to the rank of Lieutenant General. In 2000, he earned his PhD at the Faculty of Organizational Sciences. In 2001, he completed his active military career and became Ministerial Councillor of Defence at the Office of the Prime Minister of the Republic of Slovenia. From 2002 to 2006, he was Director of the Slovenian Intelligence and Security Agency and from 2004 to 2006 National Counter-Terrorism Coordinator and National Security Advisor to the President of the Republic of Slovenia. In 2006, he was habilitated as Associate Professor and pursued his academic career. The Slovenian Armed Forces Bulletin was first published on his initiative and he also acted as the publication's first Executive Editor from 1999 to 2001. 


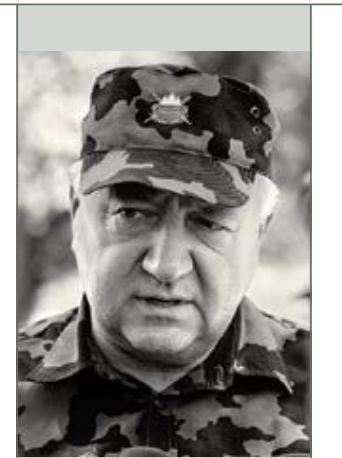

Generalmajor Ladislav Lipič je diplomiral na Fakulteti za družbene vede, smer obramboslovje. Leta 1977 se je zaposlil v Občinskem štabu TO Murska Sobota, leta 1990 pa je prevzel dolžnost pomočnika poveljnika za zaledje v Pokrajinskem štabu TO Vzhodnoštajerske pokrajine v Mariboru. Bil je aktivni udeleženec vojne za Slovenijo. Leta 1994 je bil imenovan za poveljnika pokrajinskega štaba TO Vzhodnoštajerske pokrajine, leta 1997 pa je prevzel dolžnost načelnika oddelka za logistiko v Slovenski vojski. Decembra 2000 je postal namestnik načelnika Generalštaba Slovenske vojske, marca 2001 pa je bil imenovan za načelnika. V čin generalmajorja je bil povišan leta 2003. Kariero je leta 2006 nadaljeval kot ambasador Republike Slovenije na Madžarskem, leta 2008 pa je postal svetovalec za obrambne zadeve v Uradu predsednika države. Leta 2013 je postal predsednik Zveze veteranov vojne za Slovenijo. Glavni urednik Biltena Slovenske vojske je bil v letih od 2001 do 2006 .

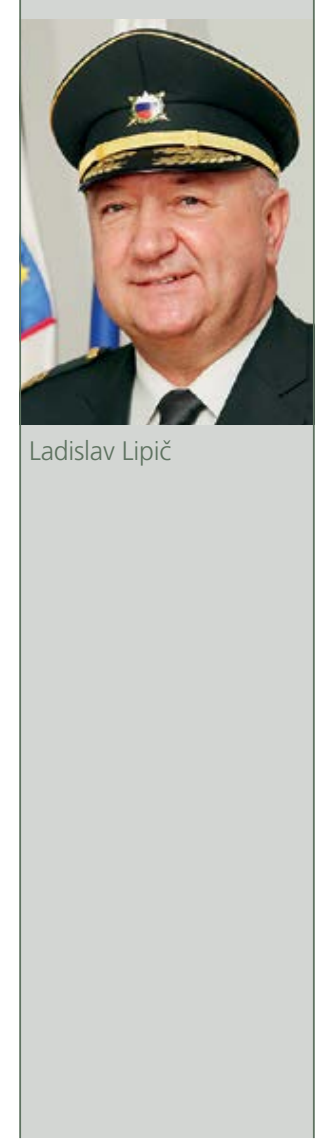

General Ladislav Lipič graduated in Defence Studies from the Faculty of Social Sciences. In 1977, he joined the Murska Sobota Municipal Staff of the Territorial Defence (TD). In 1990, he assumed the post of Assistant Rear Commander of the Regional Headquarters of Eastern Stajerska TD Region in Maribor. He was an active participant of the War for Slovenia. In 1994, he was appointed Commander of the Regional Headquarters of Eastern Štajerska TD Region, and in 1997, he assumed the duties of Chief of the Logistics Department in the Slovenian Armed Forces. In December 2000, he became Deputy Chief of the General Staff of the Slovenian Armed Forces and in March 2001, he was appointed Chief of the General Staff. He was promoted to the rank of Major General in 2003. In 2006, he continued his career as Ambassador of the Republic of Slovenia to Hungary, and in 2008, as Defence Advisor in the Office of the President of the Republic of Slovenia. In 2013, he became President of the Union of Veterans of the War for Slovenia. He acted as Executive Editor of the Slovenian Armed Forces Bulletin between 2001 and 2006. 


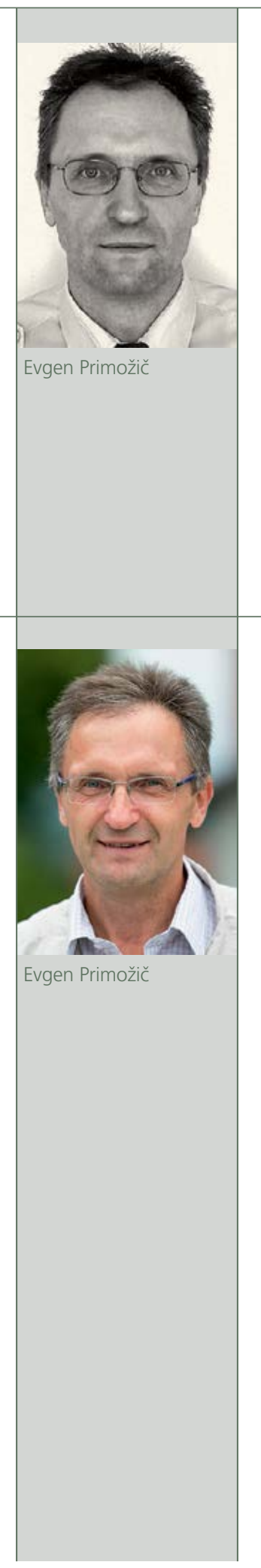

Mag. Evgen Primožič se je leta 1976 zaposlil v Teritorialni obrambi, do leta 1990 je opravljal delo pomočnika poveljnika za operativno-učne zadeve, pozneje pa je bil poveljnik občinskega štaba TO Postojna. V letih 1990 in 1991 je bil organizator obrambnih priprav na območju takratne občine Postojna. Je veteran vojne za Slovenijo.

Od leta 1992 do 1997 je bil poveljnik voda, pozneje referent za usposabljanje, samostojni pomočnik za načrtovanje in organizacijo usposabljanja, pomočnik za razvoj, projektni vodja in načelnik oddelka za celostno skrb.

Leta 2007 je opravil specializacijo, leta 2011 pa magistriral na Fakulteti za upravo.

V uredniškem odboru Biltena Slovenske vojske je sodeloval vse od njegovega nastanka kot njegov član, organizator in avtor. Od leta 2001 do 2006 je bil namestnik odgovornega urednika, od leta 2006 do 2009 pa glavni urednik.

Evgen Primožič, MSc joined the Territorial Defence In 1976. Up to 1990, he worked as Assistant Commander for Operations and Education, and later as Commander of the Territorial Defence Municipal Staff in Postojna. In 1990 and 1991, he organized defence preparations within the then municipality of Postojna. He is a veteran of the War for Slovenia.

From 1992 to 1997 he worked as platoon commander; training clerk, assistant for planning and organization of training, development assistant, project manager and, Head of the Military Welfare Department.

In 2007, he completed his specialization studies and in 2011 earned his master's degree at the Faculty of Administration. Ever since the establishment of the Slovenian Armed Forces Bulletin, he acted as member of the editorial board, organizer and author. From 2001 to 2006, he was Deputy Managing Editor and from 2006 to 2009 Executive Editor. 


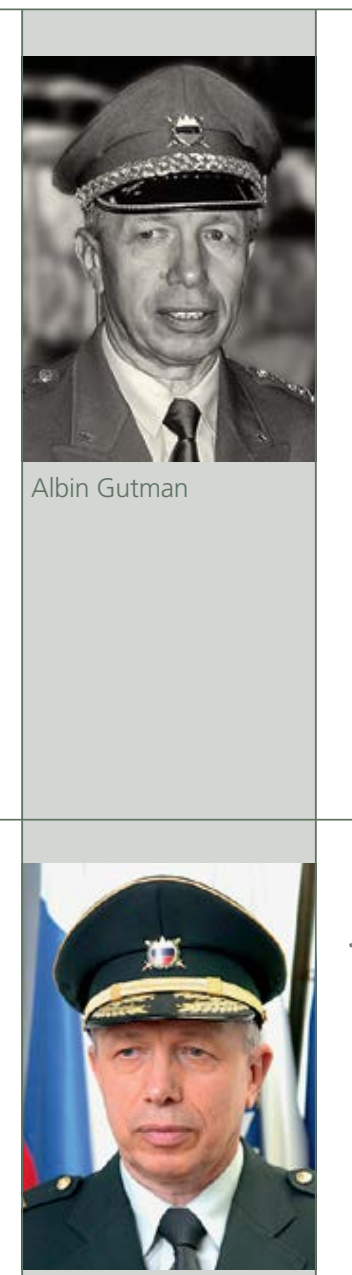

Generalpolkovnik Albin Gutman je leta 1975 diplomiral na Pedagoški akademiji in pozneje opravil specializacijo na Fakulteti za socialno delo. Leta 1976 je končal častniško šolo in se zaposlil v Teritorialni obrambi. Oktobra 1990 je bil imenovan za poveljnika pokrajinske TO za Dolenjsko. Med vojno za Slovenijo je bil vodja koordinacijske podskupine za Dolenjsko, po osamosvojitvi pa je bil namestnik ministra za obrambo in pozneje državni sekretar. Maja 1993 je postal načelnik Generalštaba Slovenske vojske. Na tej funkciji je ostal do aprila 1998, nato je bil do leta 2003 glavni inšpektor za obrambo. Načelnik Generalštaba je bil ponovno v obdobju od leta 2006 do 2009, kariero je nato nadaljeval v Direktoratu za obrambno politiko. Od leta 2012 je predsednik Zveze častnikov Slovenije.

Glavni urednik Biltena Slovenske vojske je bil v letih od 2006 do 2009 .

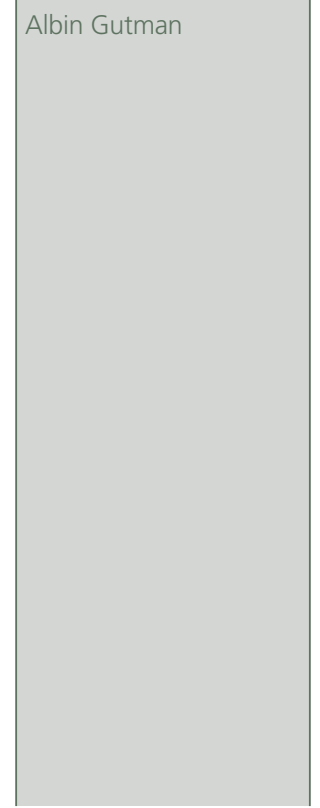

Lieutenant General Albin Gutman graduated in 1975 from the Teacher Training College and later completed specialization studies at the Faculty of Social Work. In 1976, he graduated from Officer Candidate School and began to work in the Territorial Defence. In October 1990, he was appointed Commander of the Territorial Defence Regional Headquarters of the Dolenjska Region. During the War for Slovenia, he led the coordination sub-group for the Dolenjska Region. After Slovenia won its independence, he became Deputy Minister of Defence and later Secretary of State. In May 1993, he became Chief of the General Staff of the Slovenian Armed Forces. He remained in this capacity until April 1998 and afterwards worked as Chief Defence Inspector until 2003. In the period between 2006 and 2009, he was again appointed Chief of the General Staff. Finally, he pursued his career in the Directorate of Defence Policy. Since 2012, he has been President of the Union of Slovenian Officers.

He has acted as Executive Editor of the Slovenian Armed Forces Bulletin between 2006 and 2009. 


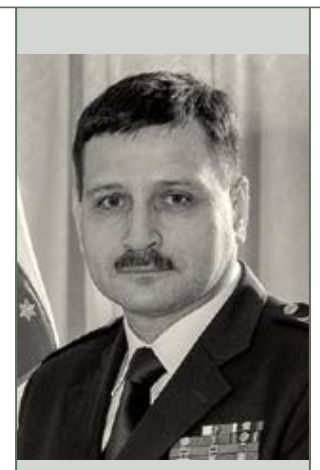

Alojz Šteiner

Generalmajor mag. Alojz Šteiner je leta 1979 nastopil službo na Občinskem štabu TO v Gornji Radgoni. Med osamosvojitveno vojno leta 1991 je opravljal dolžnost načelnika in obenem namestnika poveljnika 7. poveljstva štaba za TO v Mariboru ter aktivno sodeloval v vodenju bojnih aktivnosti.

Diplomiral je na Višji upravni šoli in Fakulteti za družbene vede $\mathrm{v}$ Ljubljani, magistriral pa na Nacionalni obrambni univerzi v Washingtonu v ZDA.

Po letu 1994 je opravljal različne dolžnosti na Generalštabu Slovenske vojske, med drugim je bil tudi načelnik sektorjev za strateško načrtovanje, doktrino in razvoj, operativne zadeve ter za strateško logistiko, namestnik poveljnika Poveljstva sil in direktor štaba na Generalštabu.

Decembra 2006 je bil postavljen na dolžnost namestnika načelnika, maja 2009 pa je bil imenovan za načelnika Generalštaba Slovenske vojske.

Glavni urednik Biltena Slovenske vojske je bil v letih 2008 in 2009.

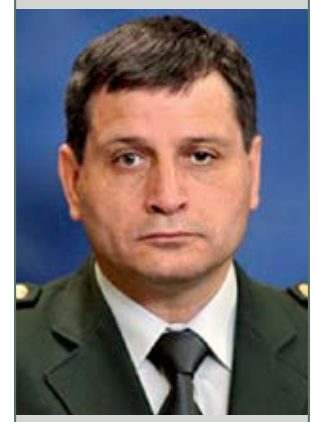

Alojz Šteiner

Major General Alojz Šteiner, MSc, started to work in the Gornja Radgona Territorial Defence (TD) Municipal Staff in 1979. During the 1991 War of Slovenia, he was Chief and Deputy Commander of the 7th Command TD Headquarters in Maribor and was actively involved in the leading of combat operations.

He graduated from the Administrative College and the Faculty of Social Sciences, and earned his master's degree at the National Defense University in Washington DC, USA.

Since 1994, he has held various positions within the General Staff of the Slovenian Armed Forces, namely chief of strategic planning, doctrine and development, operations, and strategic logistics divisions, Deputy Force Commander and Chief of Staff at the General Staff.

In December 2006, he was appointed Deputy Chief of the General Staff and in May 2009, he became Chief of the General Staff of the Slovenian Armed Forces.

He acted as Executive Editor of the Slovenian Armed Forces Bulletin in 2008 and 2009. 


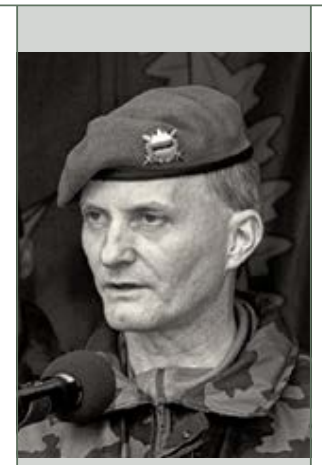

Brigadir dr. Branimir Furlan je leta 1986 končal Tehnično vojaško akademijo v Zagrebu. Slovenski vojski se je pridružil leta 1991. Bil je aktivni udeleženec vojne za Slovenijo. V svoji vojaški karieri je opravljal več različnih dolžnosti, in sicer je bil poveljnik 1. brigade od leta 2001 do leta 2005, namestnik poveljnika Poveljstva za doktrino, razvoj, izobraževanje in usposabljanje od 2005 do 2006, direktor štaba Generalštaba Slovenske vojske od 2006 do 2009 in namestnik načelnika Generalštaba od 2009 do 2010.

Branimir Furlan V čin brigadirja je bil povišan maja 2006.

Leta 2001 je magistriral na Army War College v ZDA in leta 2012 doktoriral na Fakulteti za družbene vede. Je soavtor dveh slovensko-angleških vojaških slovarjev, angleško-slovenskega terminološkega slovarja, priročnika Bojno delovanje, Pravil štabnega dela in Vojaške doktrine. Glavni urednik Sodobnih vojaških izzivov je bil od leta 2009 do leta 2012.

Trenutno je načelnik logistike v združenem poveljstvu Nata v Neaplju.

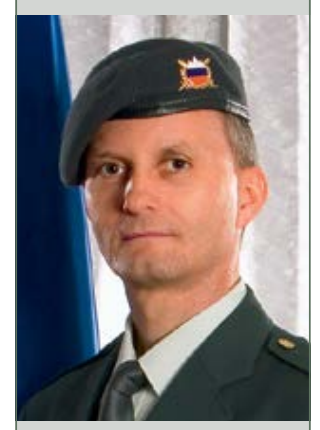

Brigadier Branimir Furlan, PhD, graduated from Technical Military Academy in Zagreb in 1986. He joined the Slovenian Armed Forces in 1991. He was an active participant of the war for Slovenia. In his military career, he has held a number of different positions, namely Commander, 1st Brigade, from 2001 to 2005; Deputy Commander of Doctrine, Development, Education and Training Command from 2005 to 2006, Chief of Staff at the General Staff of the Slovenian Armed Forces from 2006 to 2009; and Deputy Chief of the General Staff from 2009 to 2010.

He was promoted to the rank of Brigadier in May 2006.

In 2001, he earned his master's degree from the Army War College, USA and in 2012, his PhD from the Faculty of Social Sciences in Ljubljana. He co-authored two SlovenianEnglish military dictionaries, English-Slovenian dictionary of terminology, Combat Operations manual, Rules of Staff Work, and Military Doctrine. He acted as Executive Editor of the Contemporary Military Challenges from 2009 to 2012.

Currently, he is Chief of Logistics at Allied Joint Force Command Naples. 


\section{Navodila avtorjem za oblikovanje prispevkov Instructions for the authors of papers}




\section{NAVODILA AVTORJEM ZA OBLIKOVANJE PRISPEVKOV ZA SODOBNE VOJAŠKE IZZIVE IN VOJAŠKOŠOLSKI ZBORNIK}

\section{Vsebinska navodila}

Splošno Sodobni vojaški izzivi je interdisciplinarna znanstveno-strokovna publikacija, ki objavlja prispevke o aktualnih temah, raziskavah, znanstvenih in strokovnih razpravah, tehničnih ali družboslovnih analizah z varnostnega, obrambnega in vojaškega področja.

Vojaškošolski zbornik je vojaškostrokovna in informativna publikacija, namenjena izobraževanju in obveščanju o dosežkih ter izkušnjah na področju vojaškega izobraževanja, usposabljanja in izpopolnjevanja.

Kaj objavljamo?

Objavljamo prispevke v slovenskem jeziku s povzetki, prevedenimi v angleški jezik, in po odločitvi uredniškega odbora prispevke v angleškem jeziku s povzetki, prevedenimi v slovenski jezik.

Objavljamo prispevke, ki še niso bili objavljeni ali poslani v objavo drugi reviji. Pisec je odgovoren za vse morebitne kršitve avtorskih pravic. Če je bil prispevek že natisnjen drugje, poslan v objavo ali predstavljen na strokovni konferenci, naj to avtor sporočiti uredniku in pridobiti soglasje založnika (če je treba) ter navesti razloge za ponovno objavo.

\section{Tehnična navodila}

Omejitve Prispevki naj obsegajo 16 strani oziroma 30.000 znakov s presledki (avtorska dolžine prispevkov pola), izjemoma najmanj 8 strani oziroma 15.000 znakov ali največ 24 strani oziroma 45.000 znakov.

Recenzije Prispevki se recenzirajo. Recenzija je anonimna. Glede na oceno recenzentov uredniški odbor ali urednik prispevek sprejme, če je treba, zahteva popravke ali ga zavrne. Pripombe recenzentov avtor vnese v prispevek.

Zaradi anonimnega recenzentskega postopka je treba prvo stran in vsebino oblikovati tako, da identiteta avtorja ni prepoznavna.

Avtor ob naslovu prispevka napiše, v katero kategorijo po njegovem mnenju in glede na klasifikacijo v COBISS spada njegov prispevek. Klasifikacija je dostopna na spletni strani revije in pri odgovornem uredniku. Končno klasifikacijo določi uredniški odbor.

Lektoriranje Lektoriranje besedil zagotavlja OE, pristojna za založniško dejavnost. Lektorirana besedila se avtorizirajo. 
Prevajanje Prevajanje besedil ali povzetkov zagotavlja OE, pristojna za prevajalsko dejavnost oziroma Šola za tuje jezike Centra vojaških šol.

Navajanje Navajanje avtorjev je skrajno zgoraj, levo poravnano.

avtorjev Primer:

prispevka Ime 1 Priimek 1 ,

Ime 2 Priimek 2

V opombi pod črto se za slovenske avtorje navede, iz katere ustanove prihajajo. Pri tujih avtorjih je treba navesti tudi ime države.

Naslov Navedbi avtorjev sledi naslov prispevka. Črke v naslovu so velike 16 pik, natiprispevka snjene krepko, besedilo naslova pa poravnano na sredini.

Povzetek Prispevku mora biti dodan povzetek, ki obsega največ 1200 znakov (20 vrstic). Povzetek naj na kratko opredeli temo prispevka, predvsem naj povzame rezultate in ugotovitve. Splošne ugotovitve in misli ne spadajo v povzetek, temveč v uvod.

Povzetek Avtorji morajo oddati tudi prevod povzetka v angleščino. Tudi za prevod povzetka v angleščini velja omejitev do 1200 znakov (20 vrstic).

Ključne

Ključne besede (3-5, tudi $\mathrm{v}$ angleškem jeziku) naj bodo natisnjene krepko in $\mathrm{z}$ besede obojestransko poravnavo besedila.

Besedilo Avtorji naj oddajo svoje prispevke na papirju formata A4, s presledkom med vrsticami 1,5 in velikostjo črk 12 pik Arial. Na zgornjem in spodnjem robu naj bo do besedila približno $3 \mathrm{~cm}$, levi rob naj bo širok $2 \mathrm{~cm}$, desni pa $4 \mathrm{~cm}$. Na vsaki strani je tako približno 30 vrstic s približno 62 znaki. Besedilo naj bo obojestransko poravnano, brez umikov na začetku odstavka.

Kratka Avtorji morajo pripraviti kratko predstavitev svojega strokovnega oziroma znanpredstavitev stvenega dela. Predstavitev naj ne presega 600 znakov (10 vrstic, 80 besed). Če avtorjev je avtorjev več, se predstavi vsak posebej, čim bolj zgoščeno. Avtorji naj besedilo umestijo na konec prispevka po navedeni literaturi.

Struktu- $\quad$ Posamezna poglavja v besedilu naj bodo ločena s samostojnimi podnaslovi in riranje besedila ustrezno oštevilčena (členitev največ na 4 ravni).

Primer:

1 Uvod

2 Naslov poglavja (1. raven)

2.1 Podnaslov (2. raven)

2.1.1 Podnaslov (3. raven)

2.1.1.1 Podnaslov (4. raven) 
Oblikovanje V seznamu literature je treba po abecednem redu navesti le avtorje, na katere seznama se sklicujete v prispevku, celotna oznaka vira pa mora biti skladna s harvardliterature skim načinom navajanja. Če je avtorjev več, navedemo vse, kot so navedeni na izvirnem delu.

Primeri:

a) knjiga:

Priimek, ime (lahko začetnica imena), letnica. Naslov dela. Kraj: Založba.

Na primer:Urlich, W., 1983. Critical Heuristics of Social Planning. Chicago: University of Chicago Press.

b) zbornik:

Samson, C., 1970. Problems of information studies in history. V S. Stone, ur. Humanities information research. Sheffield: CRUS, 1980, str./pp. 44-68. Pri posameznih člankih v zbornikih na koncu posameznega vira navedemo strani, na katerih je članek, na primer:

c) članek v reviji

Kolega, N., 2006. Slovenian coast sea flood risk. Acta geographica Slovenica. 46-2, str. $143-167$.

Navajanje Vse reference se začenjajo enako kot pri natisnjenih virih, le da običajnemu delu virov $\mathbf{z}$ interneta sledi še podatek o tem, kje na internetu je bil dokument dobljen in kdaj. Podatek o tem, kdaj je bil dokument dobljen, je pomemben zaradi pogostega spreminjanja www okolja.

Urlich, W., 1983. Critical Heuristics of Social Planning. Chicago: University of Chicago Press, str. 45-100. http://www.mors.si/index.php?id=213, 17. 10. 2008. Pri navajanju zanimivih internetnih naslovov v besedilu (ne gre za navajanje posebnega dokumenta) zadošča navedba naslova (http://www.vpvs.uni-lj.si). Posebna referenca na koncu besedila $\mathrm{v}$ tem primeru ni potrebna.

Sklicevanje Pri sklicevanju na vire med besedilom navedite le priimek prvega avtorja in na vire letnico izdaje. Primer: ... (Smith, 1997) ...

Če dobesedno navajate del besedila, ga ustrezno označite z narekovaji, v oklepaju pa poleg avtorja in letnice navedite stran besedila, iz katerega ste navajali.

Primer: ... (Smith, 1997, str. 15) ...

Pri povzemanju drugega avtorja napišemo besedilo brez narekovajev, v oklepaju pa napišemo, da gre za povzeto besedilo. Primer: (po Smith, 1997, str. 15). Če avtorja navajamo $\mathrm{v}$ besedilu, $\mathrm{v}$ oklepaju navedemo samo letnico izida in stran (1997, str. 15). 
Slike, diagrami in tabele
Opombe pod črto

Kratice

Format zapisa prispevka

Naslov avtorja

Kako poslati prispevek

Potrjevanje sprejetja prispevka
Slike, diagrami in tabele $\mathrm{v}$ prispevku naj bodo v posebej pripravljenih datotekah, ki omogočajo lektorske popravke. V besedilu mora biti jasno označeno mesto, kamor je treba vnesti sliko. Skupna dolžina prispevka ne sme preseči dane omejitve.

Če avtor iz tehničnih razlogov grafičnih dodatkov ne more oddati v elektronski obliki, je izjemoma sprejemljivo, da slike priloži besedilu. Avtor mora $\mathrm{v}$ tem primeru na zadnjo stran slike napisati zaporedno številko in naslov, $\mathrm{v}$ besedilu pa pustiti dovolj prostora zanjo. Prav tako mora biti besedilo opremljeno z naslovom in številčenjem slike. Diagrami se štejejo kot slike. Vse slike in tabele se številčijo. Številčenje poteka enotno in ni povezano s številčenjem poglavij. Naslov slike je naveden pod sliko, naslov tabele pa nad tabelo. Navadno je v besedilu navedeno vsaj eno sklicevanje na sliko ali tabelo. Sklic na sliko ali tabelo je: ... (slika 5) ... (tabela 2) ...

Primer slike: $\quad$ Primer tabele:

Tabela 2: Naslov tabele

Slika 5: Naslov slike

Številčenje opomb pod črto je neodvisno od strukture besedila in se v vsakem prispevku začne s številko 1. Posebej opozarjamo avtorje, da so opombe pod črto namenjene pojasnjevanju misli, zapisanih v besedilu, in ne navajanju literature.

Kratice naj bodo dodane v oklepaju, ko se okrajšana beseda prvič uporabi, zato posebnih seznamov kratic ne dodajamo. Za kratico ali izraz v angleškem jeziku napišemo najprej slovensko ustreznico, v oklepaju pa angleški izvirnik in morebitno angleško kratico.

Uredniški odbor sprejema prispevke, napisane z urejevalnikom besedil MS Word, izjemoma tudi v besedilnem zapisu (text only).

Prispevkom naj bosta dodana avtorjeva naslov in internetni naslov ali telefonska številka, na katerih bo dosegljiv uredniškemu odboru.

Na naslov uredništva ali članov uredniškega odbora je treba poslati tiskano in elektronsko različico prispevka.

Uredniški odbor avtorju pisno potrdi prejetje prispevka. Avtorjem, ki sporočijo tudi naslov svoje elektronske pošte, se potrditev pošlje po tej poti. 
Korekture Avtor opravi korekture svojega prispevka v treh dneh.

Naslov Ministrstvo za obrambo

uredniškega Generalštab Slovenske vojske

odbora Sodobni vojaški izzivi

Uredniški odbor

Vojkova cesta 55

1000 Ljubljana

Slovenija

Elektronski naslov

Odgovorna urednica:

liliana.brozic@mors.si

Prispevkov, ki ne bodo urejeni skladno s tem navodilom, uredniški odbor ne bo sprejemal. 


\section{INSTRUCTIONS FOR THE AUTHORS OF PAPERS FOR THE CONTEMPORARY MILITARY CHALLENGES AND THE MILITARY EDUCATION JOURNAL}

\section{Content-related instructions}

General The Contemporary Military Challenges is an interdisciplinary scientific expert magazine, which publishes papers on current topics, researches, scientific and expert discussions, technical or social sciences analysis from the field of security, defence and the military..

The Military Education Journal is a military professional and informative publication intended for education and informing on achievements and experiences in the field of military education, training and improvement.

What do we publish?

We publish papers in Slovene with abstracts translated into English. If so decided by the Editorial Board, we also publish papers in English with abstracts translated into Slovene.

We publish papers, which have not been previously published or sent to another magazine for publication. The author is held responsible for all possible copyright violations. If the paper has already been printed elsewhere, sent for publication or presented at an expert conference, the author must notify the editor, obtain the publisher's consent (if necessary) and indicate the reasons for republishing.

\section{Technical instructions}

Limitations regarding the length of the papers
The papers should consist of 16 typewritten double-spaced pages or 30,000 characters. At a minimum they should have 8 pages or 15,000 characters and at a maximum 24 pages or 45,000 characters. 
Reviews All papers are reviewed. The review is anonymous. With regard to the reviewer's assessment, the Editorial Board or the editor accepts the paper, demands modifications, if necessary, or rejects it. Upon receiving the reviewers' remarks, the author inserts them into the paper.

Due to an anonymous review process, the first page must be designed in the way that the author's identity cannot be recognized.

Next to the title, the author should indicate the category the paper belongs to according to him and according to the classification in the COBISS ${ }^{1}$. The classification is available on the magazine's internet page and at the responsible editor. The Editorial Board determines the final classification.

Proofreading The organizational unit responsible for publishing provides the proofreading of the papers. The proofread papers have to be approved.

Translating The translation of the papers or abstracts is provided by the organizational unit competent for translation or the School of Foreign Languages, Military Schools Centre.

Indicating The authors' name should be written in the upper left corner, aligned left.

the authors Example:

of the paper Name 1 Surname 1,

Name 2 Surname 2,

In the footnote, Slovenian authors should indicate the institution they come from. Foreign authors should also indicate the name of the state they come from.

Title of the The title of the paper is written below the listed authors. The font in the title is paper bold, size 16 points. The text of the title is centrally aligned.

Abstract The paper should have an abstract of a maximum 1,200 characters (20 lines). The abstract should include a short presentation of the topic, particularly the results and the findings. General findings and reflections do not belong in the abstract, but rather in the introduction.

Abstract in The authors must also submit the translation of the abstract into English. The translaEnglish tion of the abstract is likewise limited to a maximum of 1,200 characters (20 lines).

Key words Key words (3-5 also in the English language) should be bold with a justified text alignment.

Text

The authors should submit their papers on an A4 paper format, with 1.5 line spacing, fontArial size 12 points. At the upper and the bottom edge, there should be approx. $3 \mathrm{~cm}$ of space; the left margin should be $2 \mathrm{~cm}$ wide and the right margin $4 \mathrm{~cm}$. Each page consists of approx. 30 lines with 62 characters. The text should have a justified alignment, without indents at the beginning of the paragraphs. 
A brief pre- The authors should prepare a brief presentation of their expert or scientific work. sentation of The presentation should not exceed 600 characters (10 lines, 80 words). If there the authors are several authors, each should be presented individually, as shortly and as comprehensively as possible. These texts should be placed at the end of the paper, after the cited literature.

Text structuring

Individual chapters should be separated with independent subtitles and adequately numbered.

Example:

1 Introduction

2 Title of the chapter $\left(1^{\text {st }}\right.$ level $)$

2.1 Subtitle ( $2^{\text {nd }}$ level)

2.1.1 Subtitle $\left(3^{\text {rd }}\right.$ level $)$

2.1.1.1 Subtitle $\left(4^{\text {th }}\right.$ level $)$

Referencing In the bibliography, only the authors of references one refers to in the paper should be listed, in the alphabetical order. The entire reference has to be in compliance with the Harvard citing style.

Example:

Surname, name (can also be the initial of the name), year. Title of the work. Place. Publishing House.

\section{Example:}

Urlich, W., 1983. Critical Heuristics of Social Planning. Chicago: University of Chicago Press.

With certain papers published in journals, the author should indicate, at the end of each reference, a page on which the paper can be found.

\section{Example:}

Urlich, W., 1983. Critical Heuristics of Social Planning. Chicago: University of Chicago Press. pp. 45-100.

Referencing All references start the same as the references for the printed sources, only that internet the usual part is followed by the information about the Internet page on which the document was found as well as the date on which it was found. The information about the time that the document was found on the Internet is important, because the WWW environment changes constantly.

Urlich, W., 1983. Critical Heuristics of Social Planning. Chicago: University of Chicago Press. p. 45-100. http://www.mors.si/index.php?id=213, 17 October 2008.

When referencing interesting WWW pages in the text (not citing an individual document) it is enough to state only the Internet address (http://www.vpvs.uni-lj. si). A separate reference at the end of the text is therefore not necessary. 
Citing

Figures, diagrams, tables

Footnotes

Abbreviations

Format type of the paper
When citing sources in the text, indicate only the surname of the author and the year of publication. Example: ..... (Smith, 1997) ...

When making a direct reference to a text, the cited part should be adequately marked with quotation marks and followed by the exact page of the text which the citing is taken from.

Example: ...(Smith, 1997, p.15) ...

Figures, diagrams and tables in the paper should be prepared in separate files which allow for proofreading corrections. The place in the text where the picture should be inserted must be clearly indicated. The total length of the paper must not surpass the given limitation.

Should the author not be able to submit the graphical supplements in the electronic form due to technical reasons, it is exceptionally acceptable to enclose the figures to the text. In this case the author must write a sequence number and a title on the back of each picture and leave enough space in the text to include it. The text must likewise contain the title and the sequence number of the figure. Diagrams are considered figures.

All figures and tables are numbered. The numbering is not uniform and not linked with the numbering of the chapters. The title of the figure is stated beneath it and the title of the table is stated above it.

As a rule, the paper should include at least one reference to a figure or a table.. Reference to a figure or a table is: ... (Figure 5) (Table 2) .........

Example of a figure: $\quad$ Example of a table:

Table 2: Title of the table

Figure 5: Title of the figure

The numbering of the footnotes is not related to the structure of the text and starts with number 1 in each paper. We want to stress that the aim of the footnotes is to explain the thoughts written in the text and not to reference literature.

When used for the first time, the abbreviations in the text must be explained in parenthesis; therefore no additional list of abbreviations is needed. If the abbreviations or terms are written in English, the appropriate Slovenian term should be written along with the English original and possibly the English abbreviation in the parenthesis.

The Editorial Board accepts only the texts written with a MS Word text editor and only exceptionally those in the 'text only' format. 
Author's Each paper should include the author's address, e-mail or a telephone number, so address that the Editorial Board can reach him or her.

Sending A print or an electronic version of the paper should be sent to the address of the the paper Editorial Board or the members of the Editorial Board.

Confirma- The Editorial Board sends the author a written confirmation regarding the tion of the reception of the paper. The authors who also list their e-mails receive the confirreception of mation via e-mail.

the paper

Corrections The author makes corrections to the paper within three days.

$\begin{array}{ll}\text { Editorial } & \text { Ministry of Defence } \\ \text { Board } & \text { Slovenian Armed Forces } \\ \text { address } & \text { General Staff } \\ & \text { Contemporary Military Challenges } \\ & \text { Editorial Board } \\ & \text { Vojkova cesta 55 } \\ & \text { 1000 Ljubljana } \\ & \text { Slovenia } \\ & \text { Electronic address: } \\ & \text { Editor in Chief: } \\ & \text { liliana.brozic@mors.si }\end{array}$

The Editorial Board will not accept papers, which will not be in compliance with the above instructions. 





Sodobni vojaški izzivi - 15/št. 4

Vsebina

\begin{tabular}{|c|c|}
\hline Andrej Osterman & $\begin{array}{l}\text { UVODNIK } \\
\text { EDITORIAL }\end{array}$ \\
\hline Iztok Podbregar & $\begin{array}{l}\text { BILTENU NA POT } \\
\text { THE BULLETIN SETS OUT ON ITS WAY }\end{array}$ \\
\hline Ladislav Lipič & $\begin{array}{l}\text { OB PETI OBLETNICI BILTENA SLOVENSKE VOJSKE } \\
\text { UPON THE FIFTH ANNIVERSARY OF THE SLOVENIAN ARMED FORCES BULLETIN }\end{array}$ \\
\hline Evgen Primožič & $\begin{array}{l}\text { OB TEJ IN PRIHODNJIH ŠTEVILKAH BILTENA SLOVENSKE VOJSKE } \\
\text { IN THIS AND ALL THE FOLLOWING ISSUES OF THE SLOVENIAN ARMED FORCES } \\
\text { BULLETIN }\end{array}$ \\
\hline Albin Gutman & $\begin{array}{l}\text { NOVEMU UREDNIŠKEMU ODBORU BILTENA SLOVENSKE VOJSKE NA POT } \\
\text { THE NEW EDITORIAL BOARD OF THE SLOVENIAN ARMED FORCES BULLETIN } \\
\text { SETS OUT ON ITS WAY }\end{array}$ \\
\hline Alojz Šteiner & $\begin{array}{l}\text { DESET LET IZHAJANJA BILTENA SLOVENSKE VOJSKE - NOVIM IZZIVOM NAPROTI } \\
\text { TEN YEARS OF THE SLOVENIAN ARMED FORCES BULLETIN - TOWARDS NEW } \\
\text { CHALLENGES }\end{array}$ \\
\hline Danilo Türk & $\begin{array}{l}\text { POPOTNICA BILTENU SLOVENSKE VOJSKE V DRUGO DESETLETJE } \\
\text { A GUIDE-POST FOR THE SECOND DECADE OF THE BULLETIN } \\
\text { OF THE SLOVENIAN ARMED FORCES }\end{array}$ \\
\hline Alojz Šteiner & $\begin{array}{l}\text { PROJEKTIRANJE PREOBLIKOVANJA STRUKTURE SIL VOJSKE } \\
\text { PROJECTING THE TRANSFORMATION OF MILITARY FORCE STRUCTURE }\end{array}$ \\
\hline Branimir Furlan & $\begin{array}{l}\text { RUDOLF MAISTER - STRATEŠKI VODJA } \\
\text { RUDOLF MAISTER - STRATEGIC LEADER }\end{array}$ \\
\hline Ladislav Lipič & $\begin{array}{l}\text { O RAZVOJU SLOVENSKE VOJSKE } \\
\text { ABOUT THE DEVELOPMENT OF THE SLOVENIAN ARMED FORCES }\end{array}$ \\
\hline Evgen Primožič & $\begin{array}{l}\text { TIMSKO DELO V SLOVENSKI VOJSKI } \\
\text { TEAM WORK IN THE SLOVENIAN ARMED FORCES }\end{array}$ \\
\hline Iztok Podbregar & PROLIFERACIJA OROŽJA ZA MNOŽIČNO UNIČEVANJE - JRKB/E: \\
\hline Teodora Ivanuša & $\begin{array}{l}\text { NOVODOBNI IZZIV VARNOSTNIM SILAM V BOJU PROTI TERORIZMU } \\
\text { PROLIFERATION OF CBRN/E WEAPONS: A NEW CHALLENGE FOR SECURITY } \\
\text { FORCES IN COUNTER-TERRORISM }\end{array}$ \\
\hline
\end{tabular}

